\title{
Regular treatment with salmeterol and inhaled steroids for chronic asthma: serious adverse events (Review)
}

\author{
Cates CJ, Lasserson TJ, Jaeschke R
}

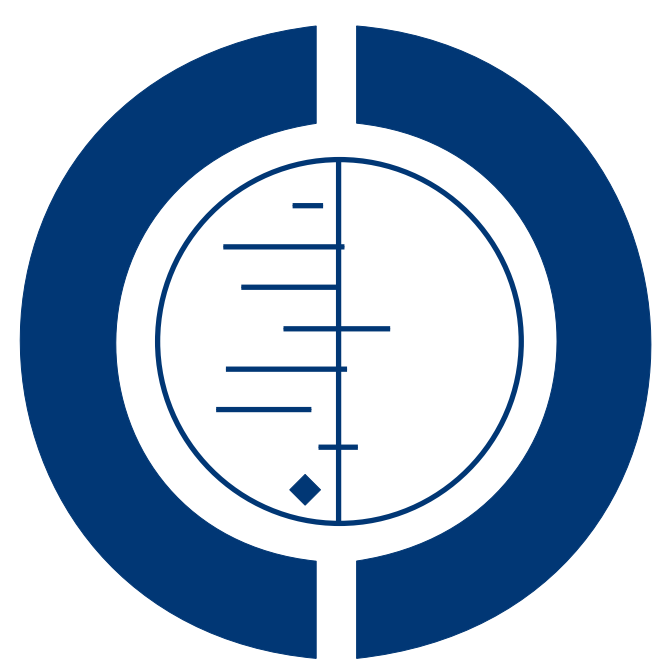

\section{THE COCHRANE COLLABORATION $^{\circledR}$}

This is a reprint of a Cochrane review, prepared and maintained by The Cochrane Collaboration and published in The Cochrane Library 2009, Issue 3

http://www.thecochranelibrary.com

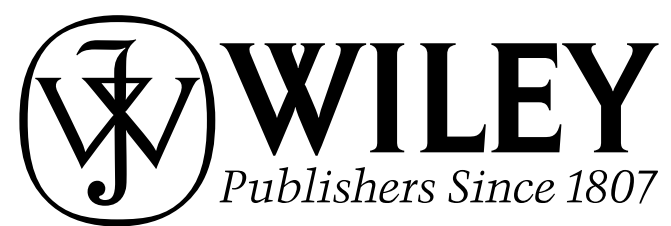

Regular treatment with salmeterol and inhaled steroids for chronic asthma: serious adverse events (Review)

Copyright (C) 2009 The Cochrane Collaboration. Published by John Wiley \& Sons, Ltd. 
TABLE OF CONTENTS

HEADER . . . . . . . . . . . . . . . . . . . . . . . . . . . . . . . . . . . . . . . . . . 1

ABSTRACT . . . . . . . . . . . . . . . . . . . . . . . . . . . . . . . . . . . . . . 1

PLAIN LANGUAGE SUMMARY $\quad . \quad$. . . . . . . . . . . . . . . . . . . . . . . . . . . . . . . . . . . . . . . . . . .

SUMMARY OF FINDINGS FOR THE MAIN COMPARISON . . . . . . . . . . . . . . . . . . . . . 2

BACKGROUND . . . . . . . . . . . . . . . . . . . . . . . . . . . . . . . . . . . . 5

OBJECTIVES . . . . . . . . . . . . . . . . . . . . . . . . . . . . . . . . . . . . . . . . . . 5

METHODS . . . . . . . . . . . . . . . . . . . . . . . . . . . . . . . . . . . . . . 5

RESULTS . . . . . . . . . . . . . . . . . . . . . . . . . . . . . . . . . . . . . . . 7

Figure 1. . . . . . . . . . . . . . . . . . . . . . . . . . . . . . . . . . . . . . 8

Figure 2. . . . . . . . . . . . . . . . . . . . . . . . . . . . . . . . . . . . . . 10

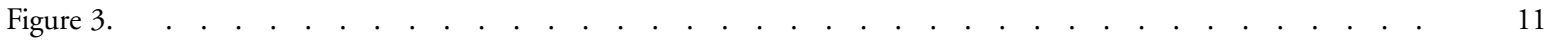

Figure $4 . \quad$. . . . . . . . . . . . . . . . . . . . . . . . . . . . . . . . . . . . . 13

Figure 5. . . . . . . . . . . . . . . . . . . . . . . . . . . . . . . . . . . 15

Figure 6. . . . . . . . . . . . . . . . . . . . . . . . . . . . . . . . . . . . 16

Figure $7 . \quad$. . . . . . . . . . . . . . . . . . . . . . . . . . . . . . . . . . . . . 17

Figure 8. . . . . . . . . . . . . . . . . . . . . . . . . . . . . . . . . . 18

Figure 9. . . . . . . . . . . . . . . . . . . . . . . . . . . . . . . . . . . . 19

Figure 10. . . . . . . . . . . . . . . . . . . . . . . . . . . . . . . . . . . . . . 20

Figure 11. . . . . . . . . . . . . . . . . . . . . . . . . . . . . . . . . . . . . . 22

DISCUSSION . . . . . . . . . . . . . . . . . . . . . . . . . . . . . . . . . . . . .

Figure 12. . . . . . . . . . . . . . . . . . . . . . . . . . . . . . . . . . . . . . 24

Figure 13. . . . . . . . . . . . . . . . . . . . . . . . . . . . . . . . . . . . . . 25

AUTHORS' CONCLUSIONS . . . . . . . . . . . . . . . . . . . . . . . . . . . . . . . . . . . . . 25

ACKNOWLEDGEMENTS . . . . . . . . . . . . . . . . . . . . . . . . . . . . . . . . . 26

REFERENCES . . . . . . . . . . . . . . . . . . . . . . . . . . . . . . . . . . . . . 26

CHARACTERISTICS OF STUDIES . . . . . . . . . . . . . . . . . . . . . . . . . . . . . . . . . . . 37

DATA AND ANALYSES . . . . . . . . . . . . . . . . . . . . . . . . . . . . . . . . . . . . . . . . . . . . . . . . $\quad .76$

Analysis 1.1. Comparison 1 Regular Salmeterol in addition to regular inhaled corticosteroids, Outcome 1 All-cause mortality. . . . . . . . . . . . . . . . . . . . . . . . . . . . . . . . . . . . 77

Analysis 1.2. Comparison 1 Regular Salmeterol in addition to regular inhaled corticosteroids, Outcome 2 All-cause nonfatal SAE.

Analysis 1.3. Comparison 1 Regular Salmeterol in addition to regular inhaled corticosteroids, Outcome 3 All-cause SAE (fatal and non-fatal).

Analysis 1.4. Comparison 1 Regular Salmeterol in addition to regular inhaled corticosteroids, Outcome 4 Asthma-related SAE.

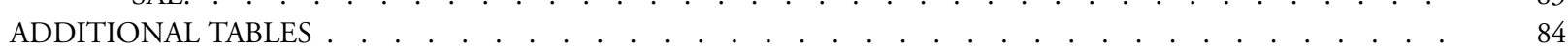

APPENDICES . . . . . . . . . . . . . . . . . . . . . . . . . . . . . . . . . . . . . 86

HISTORY . . . . . . . . . . . . . . . . . . . . . . . . . . . . . . . . . . . . . . . 89

CONTRIBUTIONS OF AUTHORS . . . . . . . . . . . . . . . . . . . . . . . . . . . . . . . . . . . . . . . 8

DECLARATIONS OF INTEREST . . . . . . . . . . . . . . . . . . . . . . . . . . . . . . . . . . . . . . . . $\quad . \quad 89$

SOURCES OF SUPPORT . . . . . . . . . . . . . . . . . . . . . . . . . . . . . . . . . . . . . . . . . . . . . 89

DIFFERENCES BETWEEN PROTOCOL AND REVIEW . . . . . . . . . . . . . . . . . . . . . . . . . . 90

INDEX TERMS . . . . . . . . . . . . . . . . . . . . . . . . . . . . . . . . . . . . . 90

Regular treatment with salmeterol and inhaled steroids for chronic asthma: serious adverse events (Review)

Copyright ( 2009 The Cochrane Collaboration. Published by John Wiley \& Sons, Ltd. 


\title{
[Intervention Review]
}

\section{Regular treatment with salmeterol and inhaled steroids for chronic asthma: serious adverse events}

\author{
Christopher J Cates ${ }^{1}$, Toby J Lasserson ${ }^{1}$, Roman Jaeschke ${ }^{2}$ \\ ${ }^{1}$ Community Health Sciences, St George's, University of London, London, UK. ${ }^{2}$ Department of Medicine, McMaster University, \\ Hamilton, Canada \\ Contact address: Christopher J Cates, Community Health Sciences, St George's, University of London, Cranmer Terrace, London, \\ SW17 0RE, UK. ccates@sgul.ac.uk.
}

Editorial group: Cochrane Airways Group.

Publication status and date: New, published in Issue 3, 2009.

Review content assessed as up-to-date: 13 April 2009.

Citation: Cates CJ, Lasserson TJ, Jaeschke R. Regular treatment with salmeterol and inhaled steroids for chronic asthma: serious adverse events. Cochrane Database of Systematic Reviews 2009, Issue 3. Art. No.: CD006922. DOI: 10.1002/14651858.CD006922.pub2.

Copyright (C) 2009 The Cochrane Collaboration. Published by John Wiley \& Sons, Ltd.

\section{A B S T R A C T}

\section{Background}

Epidemiological evidence has suggested a link between beta 2 -agonists and increased asthma mortality. There has been much debate about possible causal links for this association, and whether regular (daily) long-acting beta 2 -agonists are safe.

\section{Objectives}

The aim of this review is to assess the risk of fatal and non-fatal serious adverse events in trials that randomised patients with chronic asthma to regular salmeterol with inhaled corticosteroids versus the same dose of inhaled corticosteroids alone.

\section{Search methods}

Trials were identified using the Cochrane Airways Group Specialised Register of trials. Web sites of clinical trial registers were checked for unpublished trial data and Food and Drug Administration (FDA) submissions in relation to salmeterol were also checked. The date of the most recent search was October 2008.

\section{Selection criteria}

Controlled parallel design clinical trials on patients of any age and severity of asthma were included if they randomised patients to treatment with regular salmeterol and inhaled corticosteroids (in separate or combined inhalers), and were of at least 12 weeks duration.

\section{Data collection and analysis}

Two authors independently selected trials for inclusion in the review. Outcome data were independently extracted by two authors. Unpublished data on mortality and serious adverse events were obtained from the sponsors, and from FDA submissions.

\section{Main results}

The review included 30 studies (10,873 participants) in adults and adolescents, and three studies (1,173 participants) in children. The overall risk of bias was low and data on serious adverse events were obtained from all studies.

Six deaths occurred in 5,710 adults on regular salmeterol with inhaled corticosteroids, and five deaths in 5,163 adults on regular inhaled corticosteroids at the same dose. The difference was not statistically significant (Peto OR 1.05; 95\% CI 0.32 to 3.47) and the absolute 
difference between groups in risk of death of any cause was 0.00005 (95\% CI -0.002 to 0.002). No deaths were reported in 1,173 children, and no deaths were reported to be asthma-related.

Non-fatal serious adverse events of any cause were reported in 134 adults on regular salmeterol with inhaled corticosteroids, compared to 103 adults on regular inhaled corticosteroids; again this was not a significant increase (Peto OR 1.17; $95 \%$ CI 0.90 to 1.52 ). The absolute difference in the risk of non-fatal serious adverse events was 0.003 ( $95 \%$ CI -0.002 to 0.009 ).

There were three of 586 children with serious adverse events on regular salmeterol with inhaled corticosteroids, compared to four out of 587 on regular inhaled corticosteroids: there was no significant difference between treatments (Peto OR 0.75; 95\% CI 0.17 to 3.31 ).

Asthma-related serious adverse events were reported in 23 and 21 adults in each group respectively, a non-significant difference (Peto OR 0.95 ; $95 \%$ CI 0.52 to 1.73 ), and only one event was reported in children.

\section{Authors' conclusions}

No significant differences have been found in fatal or non-fatal serious adverse events in trials in which regular salmeterol has been randomly allocated with inhaled corticosteroids, in comparison to inhaled corticosteroids at the same dose. Although 10,873 adults and 1,173 children have been included in trials, the number of patients suffering adverse events is too small, and the results are too imprecise to confidently rule out a relative increase in all-cause mortality or non-fatal adverse events. It is therefore not possible to determine whether the increase in all-cause non-fatal serious adverse events reported in the previous meta-analysis on regular salmeterol alone is abolished by the additional use of regular inhaled corticosteroids. The absolute difference between groups in the risk of serious adverse events was small. There were no asthma-related deaths and few asthma-related serious adverse events. Clinical decisions and information for patients regarding regular use of salmeterol have to take into account the balance between known symptomatic benefits of salmeterol and the degree of uncertainty and concern associated with its potential harmful effects.

\section{PLAIN LANGUAGESUMMARY}

\section{Serious adverse events with regular salmeterol and inhaled corticosteroids}

There has been some concern raised at the possibility of increased serious adverse events following administration of salmeterol, a longacting beta 2 -agonist, to people with asthma. We analysed data from 30 studies in adults and three in children that compared regular salmeterol in addition to inhaled corticosteroids, against the same dose of inhaled corticosteroids. Too few deaths occurred in the trials to gain any conclusive reassurance that regular salmeterol taken with inhaled corticosteroids either reduces the risk of mortality, or in fact does not increase it. Serious adverse events were not significantly increased in adults or children when regular salmeterol was added to inhaled corticosteroids as randomised treatment, but the results are too imprecise to conclude that there is no increased risk. 


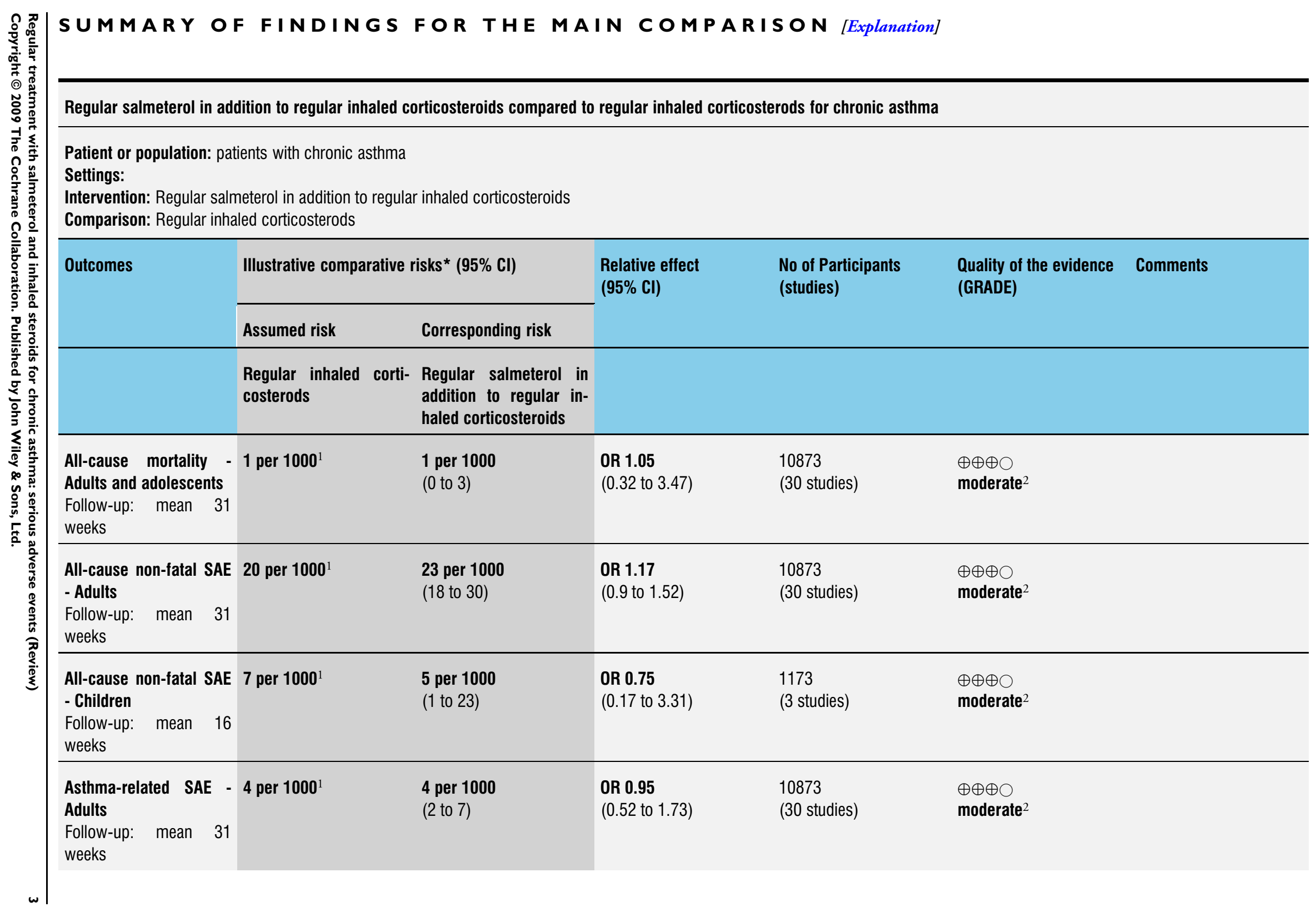




$\begin{array}{lllll}\begin{array}{l}\text { Asthma-related SAE }-2 \text { per } \mathbf{1 0 0 0}^{1} \\ \text { Children }\end{array} & \begin{array}{l}\text { O per } \mathbf{1 0 0 0} \\ (0 \text { to } 13)\end{array} & \begin{array}{l}\text { OR } \mathbf{0 . 1 4} \\ (0 \text { to } 6.82)\end{array} & \begin{array}{l}1173 \\ \text { (3 studies) }\end{array} & \begin{array}{l}\oplus \oplus \oplus \bigcirc \\ \text { moderate }\end{array} \\ \text { Follow-up: mean } 16 & & & \end{array}$

weeks

*The basis for the assumed risk (e.g. the median control group risk across studies) is provided in footnotes. The corresponding risk (and its $95 \%$ confidence interval) is based on the assumed risk in the comparison group and the relative effect of the intervention (and its $95 \% \mathrm{Cl}$ ).

Cl: Confidence interval; OR: Odds ratio;

GRADE Working Group grades of evidence

High quality: Further research is very unlikely to change our confidence in the estimate of effect.

Moderate quality: Further research is likely to have an important impact on our confidence in the estimate of effect and may change the estimate.

Low quality: Further research is very likely to have an important impact on our confidence in the estimate of effect and is likely to change the estimate.

Very low quality: We are very uncertain about the estimate.

Mean control event rate

${ }^{2}$ Wide confidence intervals due to small number of events 


\section{B A C K G R O U N D}

When patients with asthma are not controlled by low dose inhaled corticosteroids alone, many asthma guidelines recommend additional long-acting beta 2 -agonists. Several Cochrane reviews have addressed the efficacy of long-acting beta 2 -agonists in addition to inhaled corticosteroids (Ni Chroinin 2004; Ni Chroinin 2005), in comparison with placebo (Walters 2007), short-acting beta 2 -agonists (Walters 2002), leukotriene-receptor antagonists (Ducharme 2006), and increased doses of inhaled corticosteroids (Greenstone 2005). The beneficial effects of long-acting beta 2 -agonists on lung function, symptoms, quality of life and exacerbations requiring oral steroids have been demonstrated.

However, there is also longstanding controversy over the regular use of beta 2 -agonists in asthma. Sears 1986 suggested that excessive use of short acting beta 2 -agonists might have contributed directly or indirectly to increases in asthma deaths in New Zealand between 1960 and 1980. The authors comment that "most deaths were associated with poor assessment, underestimation of severity and inappropriate treatment (over-reliance on bronchodilators and under use of systemic corticosteroids), and delays in obtaining help."

Concern remains that the symptomatic benefit from treatment with long-acting beta 2 -agonists might lead to underestimation of attack severity in acute asthma, and could lead to an increase in asthma-related deaths. Furthermore, regular treatment with beta 2 agonists can lead to tolerance to their bronchodilator effects and this phenomenon may be more marked with longer acting as opposed to shorter acting compounds (Lipworth 1997). A number of molecular mechanisms have been proposed to explain the possible detrimental effect of long-term beta ${ }_{2}$-agonist use in asthma including receptor down regulation and desensitisation (Giembycz 2006).

A recent meta-analysis of the effect of long-acting beta2-agonists on severe asthma exacerbations and asthma-related deaths (Salpeter 2006) concluded that "long-acting beta-agonists have been shown to increase severe and life-threatening asthma exacerbations, as well as asthma-related deaths". Salpeter 2006 only considered trials that compared long-acting beta 2 -agonists with placebo, and the review was not able to include 28 trials in the primary analysis (including nearly 6,000 patients) because information was not provided for asthma-related deaths.

Currently there are two long-acting beta2-agonists available, salmeterol and formoterol (also known as eformoterol). These two drugs are known to have differences in receptor activity, and are used in different ways (for example salmeterol has a slower onset of action than salbutamol, and is therefore unsuitable for use as a reliever Beach 1992). 'The Fenoterol Story' is a reminder that all beta 2 -agonists may not carry the same risks (Pearce 2007), so in view of the potential difference in adverse effects between salmeterol and formoterol, we have revised our original protocol to consider the two drugs separately.
There has been much debate about the interaction between inhaled corticosteroids and long-acting beta 2 -agonists, in relation to serious adverse events, since the publication of SMART 2006. This study did not randomise patients to inhaled corticosteroids, but nevertheless a subgroup analysis of the results was carried out on the basis of inhaled corticosteroid use at baseline. It is tempting to find reassurance from the fact that there was not a statistically significant increase in asthma-related mortality in the subgroup using inhaled corticosteroids, but this is not the correct way to test for interaction (Altman 2003), and no assessment was carried out during the trial in relation to the actual use of inhaled corticosteroids during the course of the study. There is a need to systematically review all the available data from controlled trials that randomised patients to regular salmeterol in combination with inhaled corticosteroids, and to consider all serious adverse events (fatal and non-fatal), whether or not these are deemed by the investigators to be related to trial medication.

The focus of this review is therefore on regular salmeterol which has been randomised in combination with inhaled corticosteroids, (in a single inhaler or separate inhalers). Due to the difficulty in deciding whether adverse events are asthma-related (particularly in the many studies that do not have independent outcome assessment of adverse events), this review is concerned with studies that capture mortality and serious adverse events, and records both all cause outcomes, and those considered by the trial investigators to be asthma-related events. This approach differs from that of Bateman 2008 where the authors restricted the outcomes to asthma-related events.

Regular salmeterol alone is the subject of a previous review (Cates 2008a), and similarly regular formoterol alone (Cates 2008). In both of these reviews an increase in serious adverse events was demonstrated with regular long-acting beta 2 -agonists. Formoterol with inhaled corticosteroids has been considered in a further review (Cates 2009).

\section{O B J E C T I VES}

To assess the risk of mortality and non-fatal serious adverse events in trials which randomised patients with chronic asthma to regular salmeterol and inhaled corticosteroids in comparison to the same dose of inhaled corticosteroids.

\section{METHODS}

\section{Criteria for considering studies for this review}




\section{Types of studies}

Controlled parallel design clinical trials, with or without blinding, in which salmeterol and inhaled corticosteroids were randomly assigned to patients with chronic asthma. Studies on acute asthma and exercise induced bronchospasm were not included.

\section{Types of participants}

Patients with a clinical diagnosis of asthma of any age group, unrestricted by disease severity, previous or current treatment.

\section{Types of interventions}

Inhaled corticosteroids and salmeterol given regularly for a period of at least 12 weeks, at any daily dose and delivered by any single or separate devices (CFC-MDI, HFA-MDI, DPI). Studies that used comparison groups with the same dose of inhaled corticosteroids were included in this review, and co-intervention with leukotriene receptor antagonists, cromones or oral corticosteroids or theophylline was allowed as long as they were not part of the randomised intervention. Studies that compared different doses of salmeterol, or different delivery devices or propellants (with no placebo arm), or compared salmeterol with formoterol, were not included. Studies in which salmeterol was randomised without an inhaled steroid were excluded from this review, but have been considered in a separate review (Cates 2008).

\section{Types of outcome measures}

\section{Primary outcomes}

1. All cause mortality

2. All cause non-fatal serious adverse events

\section{Secondary outcomes}

1. Asthma-related mortality

2. Asthma-related non-fatal serious adverse events

3. Respiratory-related mortality

4. Respiratory-related non-fatal serious adverse events

5. Cardiovascular-related mortality

6. Cardiovascular-related non-fatal serious adverse events

7. Asthma-related non-fatal life-threatening events (intubation or admission to intensive care)

8. Respiratory-related non-fatal life-threatening events (intubation or admission to intensive care)

\section{Search methods for identification of studies}

\section{Electronic searches}

Trials were identified using the Cochrane Airways Group Specialised Register of trials, which is derived from systematic searches of bibliographic databases including the Cochrane Central Register of Controlled Trials (CENTRAL), MEDLINE, EMBASE, CINAHL, AMED, and PsycINFO, and hand searching of respiratory journals and meeting abstracts. All records in the Specialised Register coded as 'asthma' were searched using the following terms: (((beta* and agonist*) and (long-acting or "long acting")) or ((beta* and adrenergic*) and (long-acting or "long acting")) or (bronchodilat* and (long-acting or "long acting")) or (salmeterol or formoterol or eformoterol or advair or symbicort or serevent or seretide or oxis)) AND (serious or safety or surveillance or mortality or death or intubat* or adverse or toxicity or complications or tolerability)

\section{Searching other resources}

Reference lists of all primary studies and review articles were checked for additional references. Web sites of clinical trial registers were checked for unpublished trial data and FDA submissions in relation to salmeterol were also checked.

\section{Data collection and analysis}

\section{Selection of studies}

Two review authors independently assessed studies identified in the literature searches by examining titles, abstract and keywords fields. Studies that potentially fulfilled the inclusion criteria were obtained in full text. These were independently assessed by CJC and TL for inclusion. Disagreements were resolved by consensus.

\section{Data extraction and management}

Data were extracted using a prepared checklist before being entered into Rev Man 5.0 by one reviewer (CJC) with assistance from Susan Hansen, and data on trial characteristics were checked by another reviewer (TL). Outcome data were independently extracted by the third reviewer (RJ) and discrepancies resolved by discussion and correspondence with the sponsors. Data included characteristics of included studies (methods, participants, interventions, outcomes) and results of the included studies. Authors and sponsors of included studies were contacted for unpublished adverse event data, and manufacturers' web sites were searched for further details of adverse events. FDA submissions were also searched. All cause serious adverse events (fatal and non-fatal) were collected, and in view of the difficulty in deciding whether events are asthma related, details of the cause of death and serious adverse events were noted where they were available. The definition of serious adverse events was also recorded, and further information was sought if this was not clear (particularly in relation to hospital admissions and serious adverse events). 


\section{Assessment of risk of bias in included studies}

One review author (CJC) assessed the included studies for bias protection (including sequence generation for randomisation, allocation concealment, blinding of participants and assessors, loss to follow-up, completeness of outcome assessment and other possible bias prevention), with assistance from Susan Hansen.

\section{Measures of treatment effect}

The outcomes of this review were dichotomous, and we recorded the number of participants with one or more outcome events, by allocated treated group.

\section{Unit of analysis issues}

We confined our analysis to patients with one or more serious adverse event, rather than the number of events that occurred (as the latter are not independent when one patient suffers multiple events, and are therefore not suitable for meta-analysis).

\section{Assessment of heterogeneity}

Heterogeneity was assessed using $\mathrm{I}^{2}$ to indicate how much of the total heterogeneity was between studies (rather than within studies).

\section{Data synthesis}

The outcomes of this review were dichotomous, and we recorded the number of participants with at least one outcome event by allocated treated group. Pooled Odds Ratio (OR) and Risk Difference (RD) were calculated. The Peto Odds Ratio was used for the primary analysis, as no adjustment for zero cells is required. This property was more important than potential problems with unbalanced treatment arms and large effect sizes (in view of the high proportion of zero cells), but the Mantel-Haenszel method was also used for sensitivity analysis. Odds Ratios do not include the large body of evidence coming from the trials with no event in either arm, but such data is included in the analysis of absolute rates using Risk Difference. Funnel plots were inspected to assess publication bias.

\section{Subgroup analysis and investigation of heterogeneity}

Subgroup analyses were planned on the basis of age (adults versus children), severity of asthma, dose of salmeterol, and dose of inhaled corticosteroid in the comparison arms. Subgroup comparisons were made using tests for interaction (Altman 2003).

\section{Sensitivity analysis}

Sensitivity analysis was carried out to assess the impact of the method used to combine the study events (Risk Difference, Peto Odds Ratio, and Mantel-Haenszel Odds Ratio). The degree of bias protection in the study designs was also part of sensitivity analysis.

\section{RE S U L T S}

\section{Description of studies}

See: Characteristics of included studies; Characteristics of excluded studies.

\section{Results of the search}

523 abstracts were found from the search of the Cochrane Airways Group Specialised Register of trials in October 2008. For this review 97 abstracts were identified as potentially relevant. Twenty one references to 17 included studies were identified from the search of the specialised register. A further 16 studies were identified from the sponsor's web site and the reference list of a recently published review (Bateman 2008). There were 76 studies that were excluded from the review and full details of the reasons for exclusion are listed in Characteristics of excluded studies.

\section{Included studies}

Of the 33 included studies, 30 of these included 10,873 adults and adolescents (over the age of 12, 16 or 18 years according to the Characteristics of included studies). Three studies were in children up to the age of 11 years, and included 1,173 participants. The weighted mean duration was 31 weeks in the adult studies, and 16 weeks in the studies in children.

All studies were sponsored or supported by GlaxoSmithKline and compared fluticasone and salmeterol to fluticasone alone. Most studies used a single inhaler to combine the salmeterol and fluticasone. The dose of salmeterol used was 50 mcg twice daily in all studies except for SAS30021, SAS30022 and SAS30023 in which a once daily dose of $50 \mathrm{mcg}$ was used. The dose of fluticasone varied from 100 to $1000 \mathrm{mcg} /$ day (see Table 1 ), and some studies stratified patients to different daily doses of fluticasone, but used the same daily dose of fluticasone in each stratum for comparison with additional salmeterol (Koenig 2008; SAM30007; SAM40031; SAM40065).

\section{Risk of bias in included studies}

An overview of the risk of bias in individual studies is shown in Figure 1 
Figure I. Methodological quality summary: review authors' judgements about each methodological quality item for each included study.

\begin{tabular}{|c|c|c|c|c|c|}
\hline & 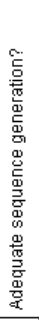 & 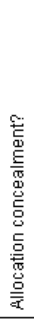 & $\begin{array}{l}\text { 氕 } \\
\text { 訔 } \\
\text { 言 }\end{array}$ & 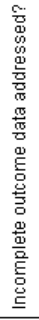 & 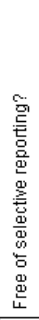 \\
\hline Aubier 1999 & $?$ & $?$ & $\odot$ & + & 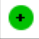 \\
\hline Bateman 2001 & $?$ & $?$ & $\odot$ & $\odot$ & + \\
\hline GOAL 2004 & $\odot$ & $?$ & $\odot$ & 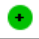 & $\odot$ \\
\hline Ind 2003 & $?$ & $?$ & + & $\odot$ & + \\
\hline Kavuru 2000 & $?$ & $?$ & $\odot$ & + & 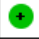 \\
\hline Koenig 2008 & $?$ & $?$ & $\odot$ & $\odot$ & + \\
\hline Koopmans 2006 & $?$ & $?$ & 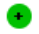 & $\odot$ & + \\
\hline Lundback 2006 & $?$ & $?$ & + & $\odot$ & + \\
\hline Malone 2005 & $?$ & ? & $\odot$ & $\odot$ & + \\
\hline Murray 2004 & $\odot$ & $?$ & $\odot$ & $\odot$ & + \\
\hline Nathan 2006 & $?$ & ? & + & + & + \\
\hline Nelson 2003 & $?$ & $?$ & $\odot$ & + & + \\
\hline Pearlman 2004 & $?$ & ? & + & ? & + \\
\hline Rojas 2007 & $?$ & $?$ & $\odot$ & + & + \\
\hline SAM 30007 & $?$ & $?$ & $\odot$ & + & + \\
\hline SAM40004 & $?$ & $?$ & $\odot$ & - & + \\
\hline SAM40008 & $?$ & $?$ & $\odot$ & $\Theta$ & + \\
\hline SAM40012 & $?$ & $?$ & + & + & + \\
\hline SAM40031 & $?$ & $?$ & + & + & + \\
\hline SAM 40065 & $?$ & $?$ & $\odot$ & $\odot$ & + \\
\hline SAS30021 & $?$ & ? & $\odot$ & + & + \\
\hline SAS30022 & $?$ & ? & + & $?$ & + \\
\hline SAS30023 & $?$ & $?$ & $\odot$ & + & + \\
\hline SAS40036 & $?$ & ? & $\odot$ & + & + \\
\hline SAS40037 & $?$ & $?$ & $\odot$ & + & + \\
\hline SAS40068 & $?$ & ? & $\odot$ & + & + \\
\hline SFA103153 & $?$ & ? & $\odot$ & $\odot$ & + \\
\hline $\mathrm{SFCF} 4026$ & $?$ & $?$ & + & + & + \\
\hline Shapiro 2000 & $?$ & ? & $\odot$ & + & + \\
\hline SLGF75 & $?$ & ? & $\odot$ & + & + \\
\hline Strand 2004 & $?$ & ? & $\odot$ & + & + \\
\hline van Noord 2001 & $?$ & ? & $\odot$ & + & + \\
\hline Wallin 2003 & $?$ & $?$ & + & $\odot$ & $\odot$ \\
\hline
\end{tabular}




\section{Allocation}

Sequence generation and allocation concealment are not well reported, but correspondence with the sponsors indicates that standard methodology (as required by regulatory authorities), has been used to protect against selection bias in these studies. We therefore regard the risk of selection bias as low.

\section{Blinding}

All of the studies were reported as double blind, and doubledummy design was incorporated when the inhaler devices were not the same in each arm.

\section{Selective reporting}

Data have been found or provided from the sponsor for all-cause fatal and non-fatal serious adverse events by treatment group for all studies.

\section{Other potential sources of bias}

All studies were sponsored by GlaxoSmithKline, the manufacturers of salmeterol and salmeterol/fluticasone inhalers.

\section{Effects of interventions}

See: Summary of findings for the main comparison Serious adverse events

\section{Primary Outcomes}

\section{All cause mortality}

\section{Adults and adolescents}

In the adult and adolescent studies there were six deaths (out of 5,170 participants) on salmeterol with inhaled corticosteroids and five deaths (out of 5,163 participants) on inhaled corticosteroids alone. The pooled Odds Ratio in adults and adolescents was not statistically significant, (Peto OR 1.05; 95\% CI 0.32 to 3.47) and $\mathrm{I}^{2}$ was zero, but the confidence interval is wide due to the small number of deaths, and still includes the possibility of a three-fold increase in mortality, as well as a three-fold reduction Figure 2. The pooled risk difference from these studies is shown in Figure 3, (RD $0.00005 ; 95 \%$ CI - 0.002 to 0.002 ). In other words, for every 1,000 patients treated with salmeterol and inhaled corticosteroids for 31 weeks, the results are compatible with both a possible increase or decrease of up to two deaths. 
Figure 2. Forest plot of comparison: I Regular Salmeterol in addition to regular inhaled corticosteroids, outcome: I.I All-cause mortality.

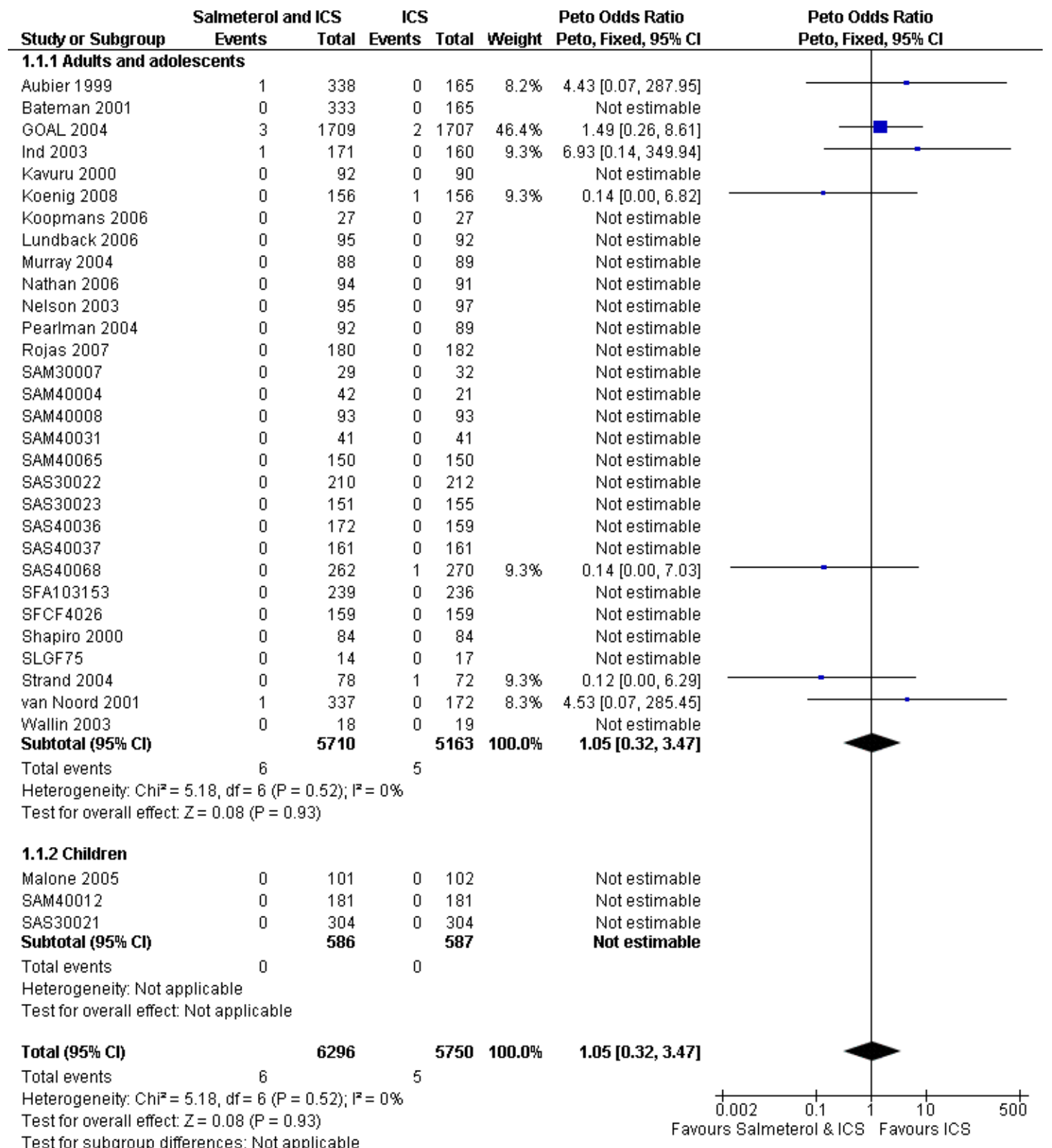


Figure 3. Forest plot of comparison: I Regular Salmeterol in addition to regular inhaled corticosteroids, outcome: I.I All-cause mortality (Risk Difference)

\begin{tabular}{|c|c|c|c|c|c|c|c|}
\hline \multirow{2}{*}{ Study or Subgroup } & \multicolumn{2}{|c|}{ Salmeterol and ICS } & \multicolumn{2}{|c|}{ ICS } & \multirow[b]{2}{*}{ Weight } & \multirow{2}{*}{$\begin{array}{l}\text { Risk Difference } \\
\text { M-H, Fixed, 95\% } \mathrm{Cl}\end{array}$} & \multirow{2}{*}{$\begin{array}{c}\text { Risk Difference } \\
\text { M-H, Fixed, 95\% Cl }\end{array}$} \\
\hline & Events & Total & Events & Total & & & \\
\hline \multicolumn{8}{|c|}{ 1.1.1 Adults and adolescents } \\
\hline Aubier 1999 & 1 & 338 & 0 & 165 & $3.7 \%$ & $0.00[-0.01,0.01]$ & \\
\hline Bateman 2001 & 0 & 333 & 0 & 165 & $3.7 \%$ & $0.00[-0.01,0.01]$ & \\
\hline GOAL 2004 & 3 & 1709 & 2 & 1707 & $28.8 \%$ & $0.00[-0.00,0.00]$ & \\
\hline Ind 2003 & 1 & 171 & 0 & 160 & $2.8 \%$ & $0.01[-0.01,0.02]$ & \\
\hline Kavuru 2000 & 0 & 92 & 0 & 90 & $1.5 \%$ & $0.00[-0.02,0.02]$ & \\
\hline Koenig 2008 & 0 & 156 & 1 & 156 & $2.6 \%$ & $-0.01[-0.02,0.01]$ & \\
\hline Koopmans 2006 & 0 & 27 & 0 & 27 & $0.5 \%$ & $0.00[-0.07,0.07]$ & \\
\hline Lundback 2006 & 0 & 95 & 0 & 92 & $1.6 \%$ & $0.00[-0.02,0.02]$ & \\
\hline Murray 2004 & 0 & 88 & 0 & 89 & $1.5 \%$ & $0.00[-0.02,0.02]$ & \\
\hline Nathan 2006 & 0 & 94 & 0 & 91 & $1.6 \%$ & $0.00[-0.02,0.02]$ & \\
\hline Nelson 2003 & 0 & 95 & 0 & 97 & $1.6 \%$ & $0.00[-0.02,0.02]$ & \\
\hline Pearlman 2004 & 0 & 92 & 0 & 89 & $1.5 \%$ & $0.00[-0.02,0.02]$ & \\
\hline Rojas 2007 & 0 & 180 & 0 & 182 & $3.1 \%$ & $0.00[-0.01,0.01]$ & \\
\hline SAM 30007 & 0 & 29 & 0 & 32 & $0.5 \%$ & $0.00[-0.06,0.06]$ & \\
\hline SAM40004 & 0 & 42 & 0 & 21 & $0.5 \%$ & $0.00[-0.07,0.07]$ & \\
\hline SAM 40008 & 0 & 93 & 0 & 93 & $1.6 \%$ & $0.00[-0.02,0.02]$ & \\
\hline SAM 40031 & 0 & 41 & 0 & 41 & $0.7 \%$ & $0.00[-0.05,0.05]$ & \\
\hline SAM40065 & 0 & 150 & 0 & 150 & $2.5 \%$ & $0.00[-0.01,0.01]$ & \\
\hline SAS30022 & 0 & 210 & 0 & 212 & $3.6 \%$ & $0.00[-0.01,0.01]$ & \\
\hline SAS30023 & 0 & 151 & 0 & 155 & $2.6 \%$ & $0.00[-0.01,0.01]$ & \\
\hline SAS40036 & 0 & 172 & 0 & 159 & $2.8 \%$ & $0.00[-0.01,0.01]$ & \\
\hline SAS40037 & 0 & 161 & 0 & 161 & $2.7 \%$ & $0.00[-0.01,0.01]$ & \\
\hline SAS40068 & 0 & 262 & 1 & 270 & $4.5 \%$ & $-0.00[-0.01,0.01]$ & \\
\hline SFA103153 & 0 & 239 & 0 & 236 & $4.0 \%$ & $0.00[-0.01,0.01]$ & \\
\hline SFCF 4026 & 0 & 159 & 0 & 159 & $2.7 \%$ & $0.00[-0.01,0.01]$ & \\
\hline Shapiro 2000 & 0 & 84 & 0 & 84 & $1.4 \%$ & $0.00[-0.02,0.02]$ & \\
\hline SLGF75 & 0 & 14 & 0 & 17 & $0.3 \%$ & $0.00[-0.12,0.12]$ & \\
\hline Strand 2004 & 0 & 78 & 1 & 72 & $1.3 \%$ & $-0.01[-0.05,0.02]$ & \\
\hline van Noord 2001 & 1 & 337 & 0 & 172 & $3.8 \%$ & $0.00[-0.01,0.01]$ & \\
\hline Wallin 2003 & 0 & 18 & 0 & 19 & $0.3 \%$ & $0.00[-0.10,0.10]$ & $\longleftarrow$ \\
\hline Subtotal $(95 \% \mathrm{Cl})$ & & 5710 & & 5163 & $90.1 \%$ & $0.00[-0.00,0.00]$ & \\
\hline Total events & 6 & & 5 & & & & \\
\hline \multicolumn{8}{|c|}{ Heterogeneity: $\mathrm{Ch}^{2}=2.79, \mathrm{df}=29(\mathrm{P}=1.00) ; \mathrm{I}^{2}=0 \%$} \\
\hline \multicolumn{8}{|c|}{ Test for overall effect: $Z=0.04(P=0.97)$} \\
\hline \multicolumn{8}{|l|}{ 1.1.2 Children } \\
\hline Malone 2005 & 0 & 101 & 0 & 102 & $1.7 \%$ & $0.00[-0.02,0.02]$ & \\
\hline SAM40012 & 0 & 181 & 0 & 181 & $3.1 \%$ & $0.00[-0.01,0.01]$ & \\
\hline SAS30021 & 0 & 304 & 0 & 304 & $5.1 \%$ & $0.00[-0.01,0.01]$ & \\
\hline Subtotal (95\% Cl) & & 586 & & 587 & $9.9 \%$ & $0.00[-0.01,0.01]$ & \\
\hline Total events & 0 & & 0 & & & & \\
\hline \multicolumn{8}{|c|}{ Heterogeneity: $\mathrm{Chi}^{2}=0.00, \mathrm{df}=2(\mathrm{P}=1.00) ;\left.\right|^{2}=0 \%$} \\
\hline \multicolumn{8}{|c|}{ Test for overall effect: $Z=0.00(P=1.00)$} \\
\hline Total $(95 \% \mathrm{Cl})$ & & 6296 & & 5750 & $100.0 \%$ & $0.00[-0.00,0.00]$ & \\
\hline Total events & 6 & & 5 & & & & \\
\hline \multicolumn{7}{|c|}{ Heterogeneity: $\mathrm{Chi}^{2}=2.79, \mathrm{df}=32(\mathrm{P}=1.00) ; \mathrm{I}^{2}=0 \%$} & 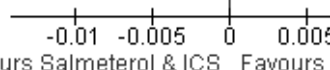 \\
\hline
\end{tabular}


None of the deaths were reported as being related to asthma. There was one death from bronchial carcinoma in Aubier 1999 in a patient on separate salmeterol and fluticasone inhalers, two deaths from myocardial infarction in each arm of GOAL 2004 and one additional death from pneumonia on salmeterol/fluticasone, one death from pneumothorax in Ind 2003 on separate salmeterol and fluticasone, one death from cardiac arrest and deep vein thrombosis in Koenig 2008 on fluticasone, one death in SAS40068 from ventricular hypertrophy and aortic hypoplasia on fluticasone, one death of unknown cause in Strand 2004 on fluticasone, and one death in van Noord 2001 from leukaemia on combination salmeterol/fluticasone pMDI.

\section{Children}

No deaths were reported in the three studies on children $(1,173$ participants). It is not possible to calculate any Odds Ratios from this data, but the pooled Risk Difference can be assessed with a confidence interval, (RD 0.00 ; $95 \%$ CI -0.006 to 0.006 ). In other words, for every 1000 patients treated with salmeterol and inhaled corticosteroids for 16 weeks, the $95 \%$ confidence interval is compatible with either an increase or decrease of up to a maximum of six deaths.

\section{Serious Adverse Events (non-fatal all cause)}

A serious adverse event is defined as an event that falls in any of the following categories:

- Results in death,

- Is life-threatening,

- Requires inpatient hospitalization or prolongation of existing hospitalization,

- Results in persistent or significant disability/incapacity, or

- Is a congenital anomaly/birth defect.

This is the definition from the International Conference on Harmonisation (ICH), and we have assumed that this definition was used in the trials (even though this was often not explicitly reported in the papers, it is the standard definition for regulatory trials ICHE2a 1995).

\section{Adults and Adolescents}

The number of patients experiencing one or more non-fatal serious adverse events was similar when salmeterol was given with inhaled corticosteroids in comparison to inhaled corticosteroids alone. There were 134 out of 5710 (2.3\%) participants on regular salmeterol with ICS and 103 out of $5163(2.0 \%)$ on ICS alone. The Peto Odds Ratio was 1.17 (95\% CI 0.90 to 1.52$)$ and $\mathrm{I}^{2}$ was zero (Figure 4). The pooled RD was 0.003 (95\% CI -0.002 to 0.009 ). For every 1,000 patients treated with salmeterol and inhaled corticosteroids for 31 weeks, the results are compatible with both a possible decrease of up to two patients or an increase of up to nine patients with a serious adverse event. 
Figure 4. Forest plot of comparison: I Regular Salmeterol in addition to regular inhaled corticosteroids, outcome: I.2 All-cause non-fatal SAE.

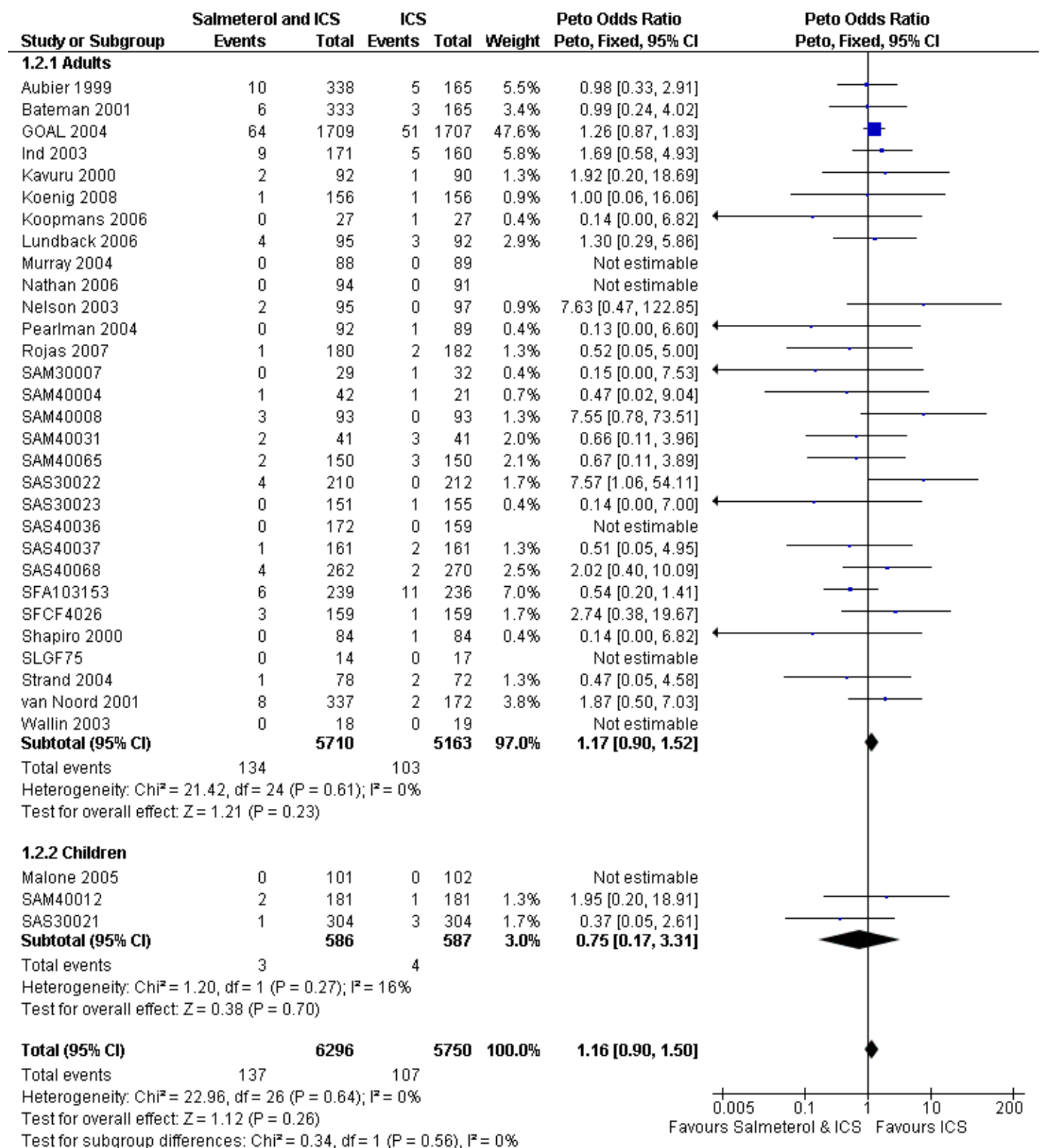




\section{Children}

In the trials in children there were three out of $586(0.5 \%)$ participants with serious adverse events on regular salmeterol with ICS and four out of $587(0.7 \%)$ on ICS alone. The Peto Odds Ratio was 0.75 (95\% CI 0.17 to 3.31 ) and $\mathrm{I}^{2}$ was $16 \%$, and the pooled RD for children was -0.002 ( $95 \%$ CI -0.01 to 0.008 ). For every 1,000 children treated with salmeterol and inhaled corticosteroids for 16 weeks, the results are compatible with both a possible decrease of up to ten children or an increase of up to eight children with a serious adverse event.

The test for interaction between adults and children did not find a significant impact of age on the treatment effect.

\section{Secondary Outcomes}

\section{Mortality by cause of death}

None of the deaths were reported to be due to asthma.

\section{Serious Adverse Events related to Asthma}

\section{Adults and Adolescents}

The number of patients experiencing one or more asthma related non-fatal serious adverse events was similar when salmeterol was given with inhaled corticosteroids in comparison to inhaled corticosteroids alone. There were 23 out of $5710(0.4 \%)$ participants on regular salmeterol with ICS and 21 out of $5163(0.4 \%)$ on ICS alone. The Peto Odds Ratio was 0.95 (95\% CI 0.52 to 1.73 ) and I 2 was zero (Figure 5). The pooled RD was -0.002 (95\% CI -0.003 to 0.003$)$. 
Figure 5. Forest plot of comparison: I Regular Salmeterol in addition to regular inhaled corticosteroids, outcome: I.3 Asthma-related SAE.

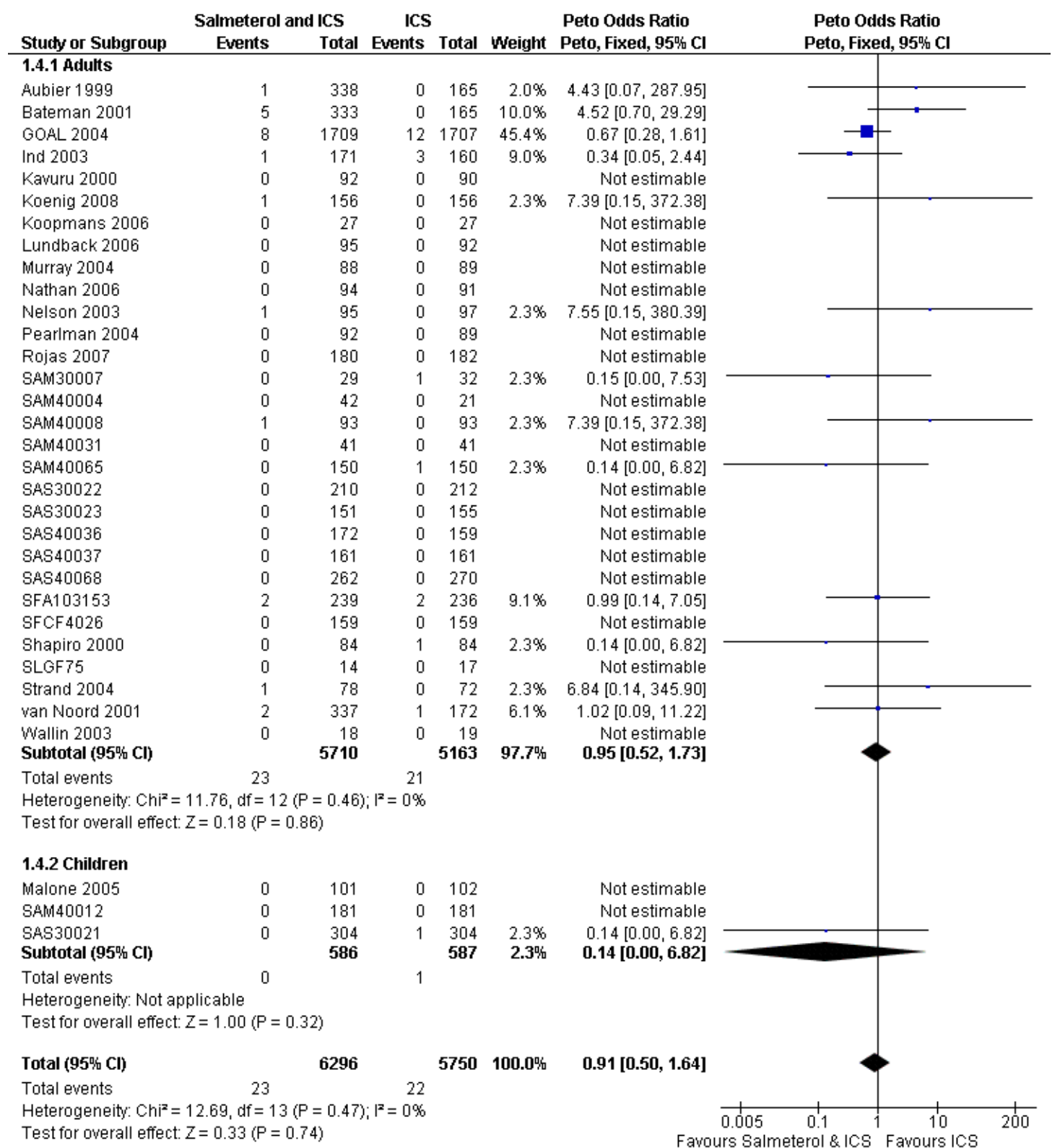




\section{Children}

In the trials in patients who were less than 12 years of age none of the children (out of 586) had an asthma-related serious adverse event on regular salmeterol with ICS and one out of $587(0.2 \%)$ on ICS alone. The Peto Odds Ratio showed no significant difference with wide confidence intervals (Peto OR 0.14; $95 \%$ CI 0.00 to 6.82). The pooled RD was -0.002 ( $95 \%$ CI -0.008 to 0.005 ).

The difference between children and adults was again not statistically significant. We did not find data to assess the other proposed secondary outcomes (such as ITU admission and intubation).

\section{Sensitivity Analyses}

\section{Risk of bias}

No unblinded studies were identified. A funnel plot of non-fatal serious adverse events did not suggest obvious publication bias Figure 6.

Figure 6. Funnel plot of comparison: I Regular Salmeterol in addition to regular inhaled corticosteroids, outcome: I.2 All-cause non-fatal SAE.

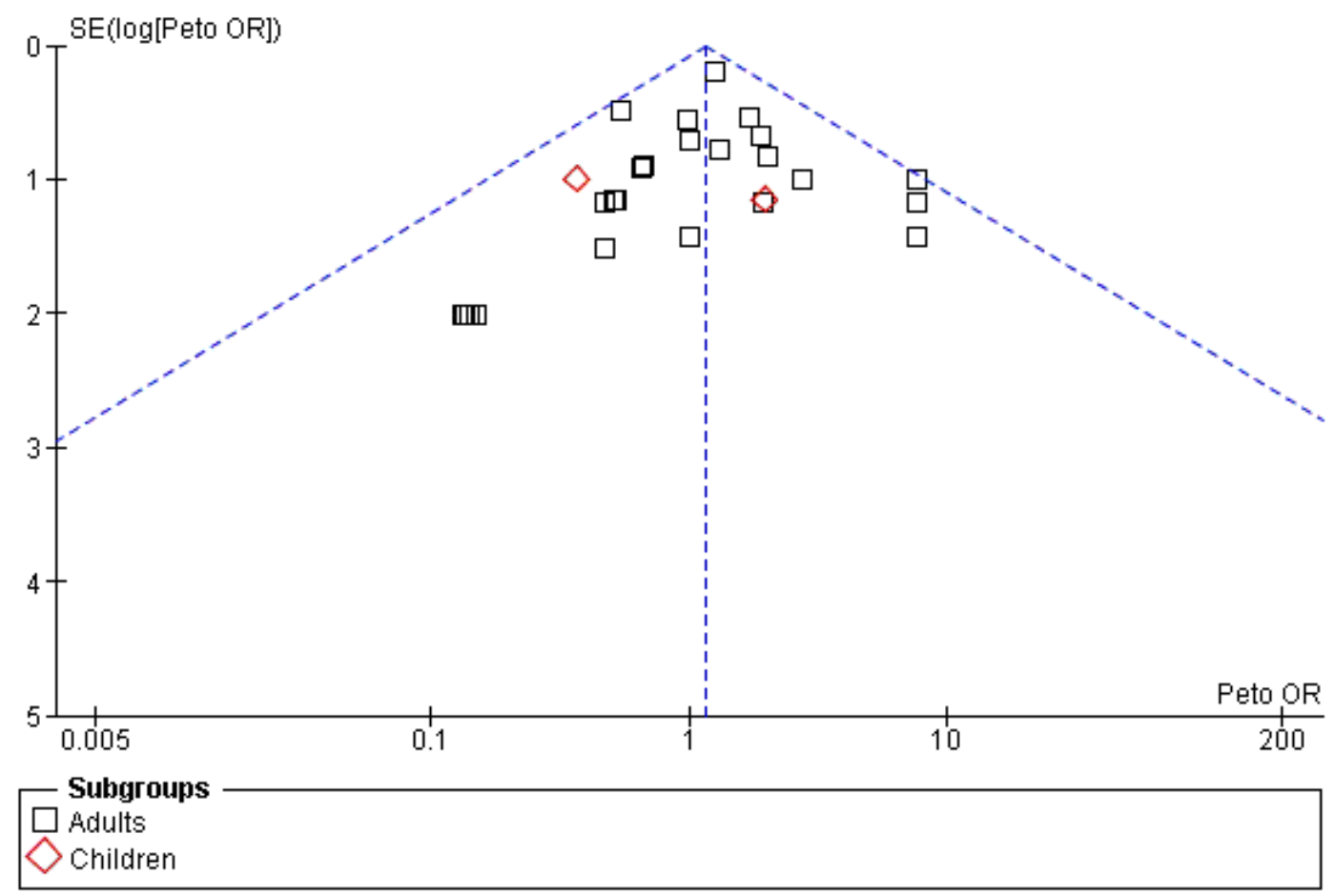

\section{Methods of analysis}

The primary outcomes were also analysed using Mantel-Haenszel fixed and random effects models. The results of the fixed effects model for mortality are shown in Figure 7. This method uses a correction for zero cells which is not required for the Peto OR. With this method the addition of 0.5 to all cells when the arms have similar numbers randomised will generate an OR of 3 when there is only one event in the treatment group and none in the control group. When there are very sparse outcomes (such as for mortality), the calculated OR is entirely dependent on the size of the zero cell adjustment, and whether the treatment arms are balanced. Although the direction of effect changes using the MantelHaenszel model (OR 0.95; 95\% CI 0.36 to 2.50 ), the confidence 
interval is very similar and the results clearly remain non-signifi-

cant.

Figure 7. Forest plot of comparison: I Regular Salmeterol in addition to regular inhaled corticosteroids, outcome: I.I All-cause mortality (Mantel-Haenzel Fixed effects)

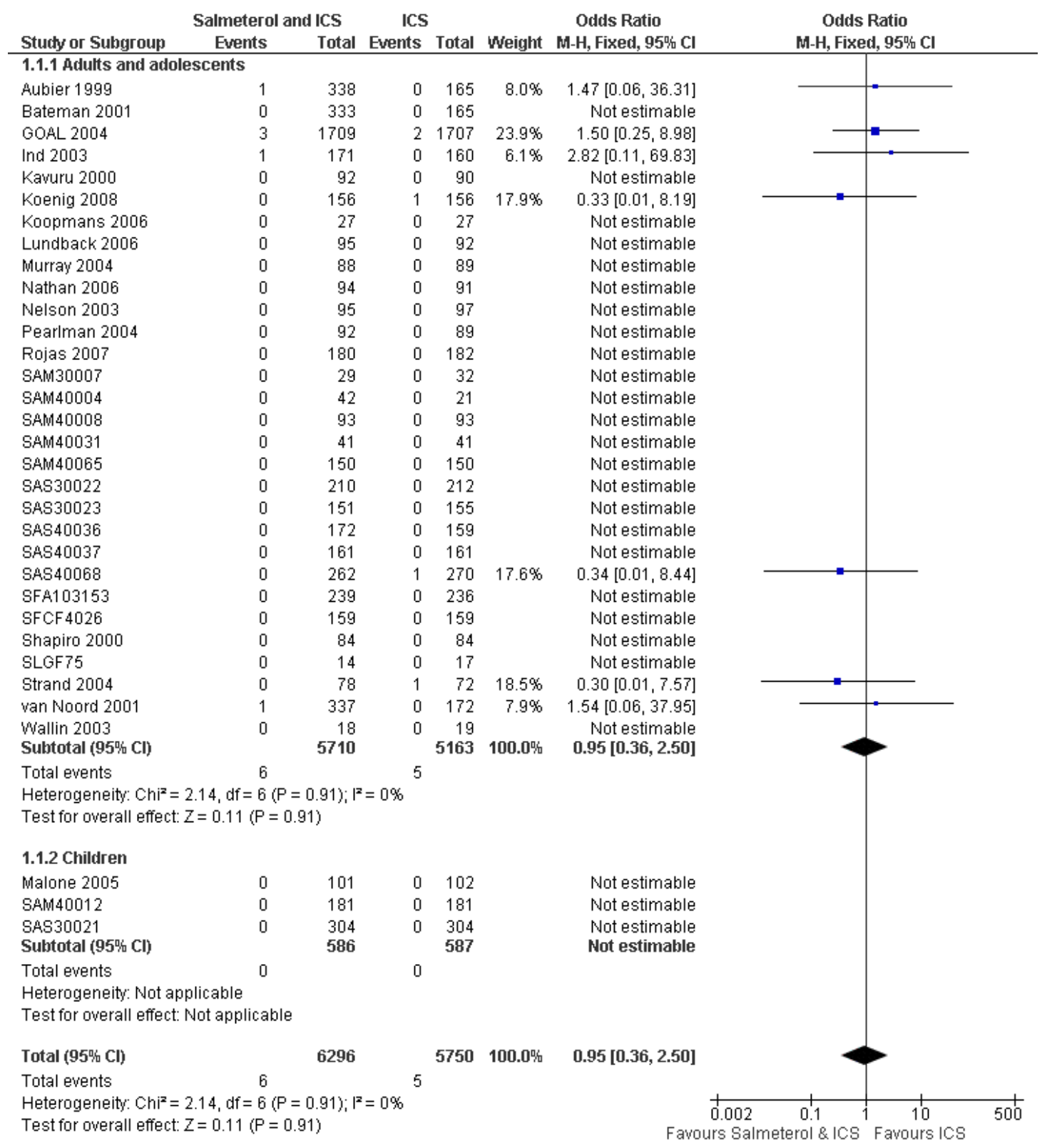


For non-fatal serious adverse events in adults the Peto method (Peto OR 1.17; 95\% CI 0.90 to 1.52 ) gave almost identical results to Mantel-Haenszel fixed effects model (OR 1.17; 95\% CI 0.90 to 1.51) Figure 8 or Mantel-Haenszel random effects (OR 1.14; 95\% CI 0.87 to 1.49$)$ Figure 9.

Figure 8. Forest plot of comparison: I Regular Salmeterol in addition to regular inhaled corticosteroids, outcome: I.2 All-cause non-fatal SAE (Mantel-Haenszel fixed effects)

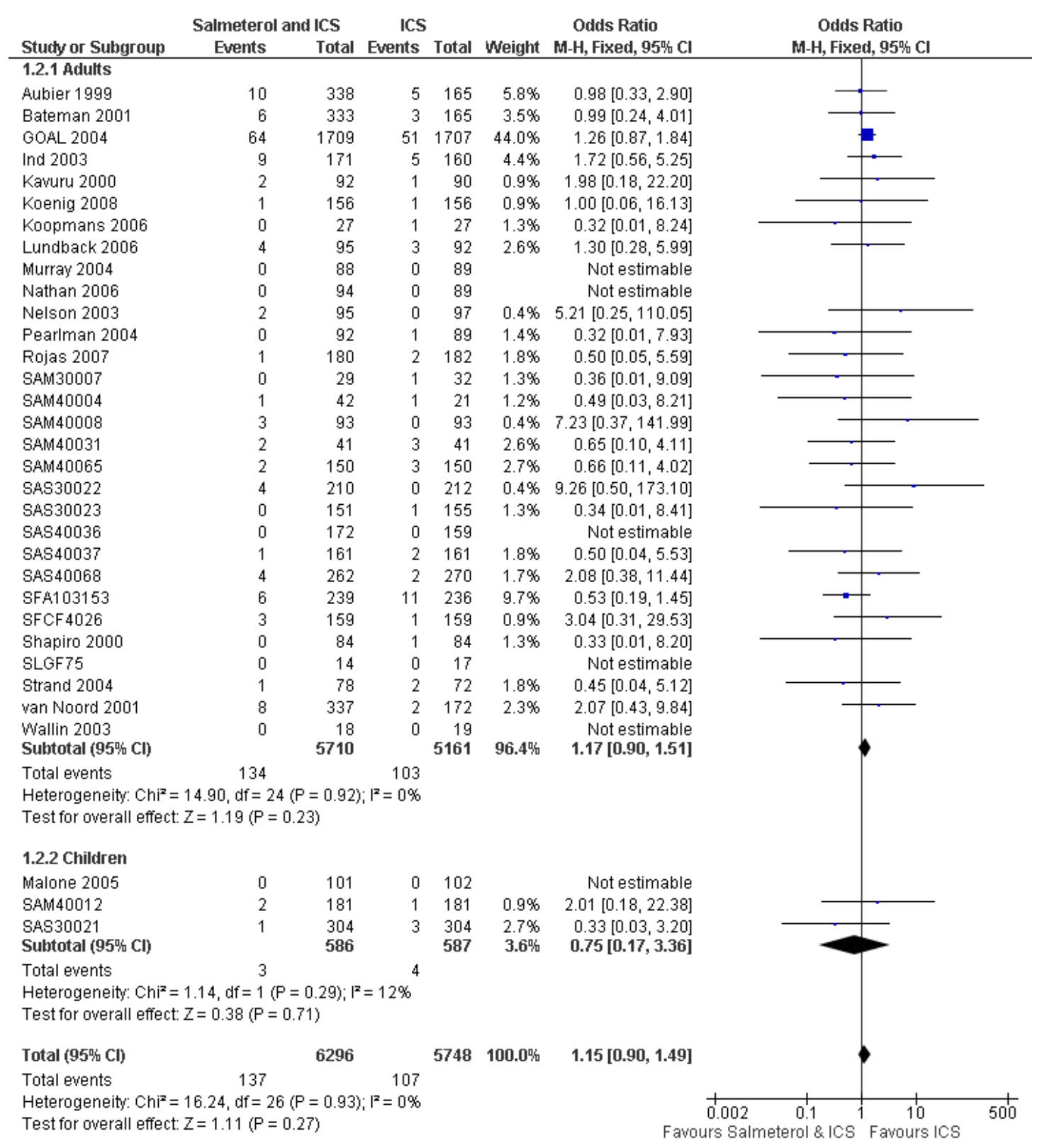


Figure 9. Forest plot of comparison: I Regular Salmeterol in addition to regular inhaled corticosteroids, outcome: I.2 All-cause non-fatal SAE (Mantel-Haenszel random effects)

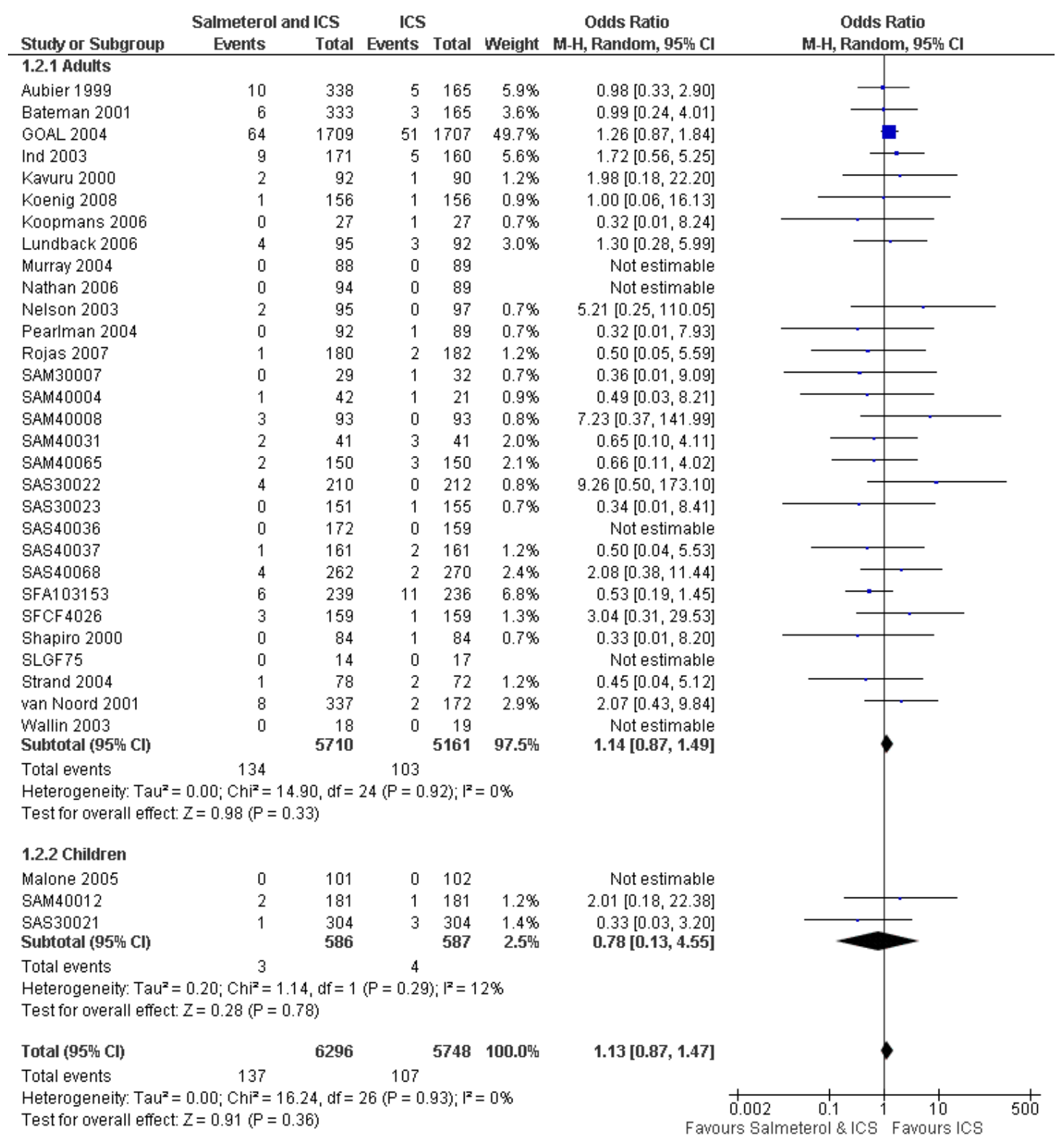


When fatal and non-fatal serious adverse events were combined the results for adults were almost identical to the pooled result for the non-fatal events in adults (Peto OR 1.17; 95\% CI 0.91 to 1.51), and were unchanged in children as there were no deaths in children Figure 10.

Figure 10. Forest plot of comparison: I Regular Salmeterol in addition to regular inhaled corticosteroids, outcome: I.3 All-cause SAE (fatal and non-fatal)

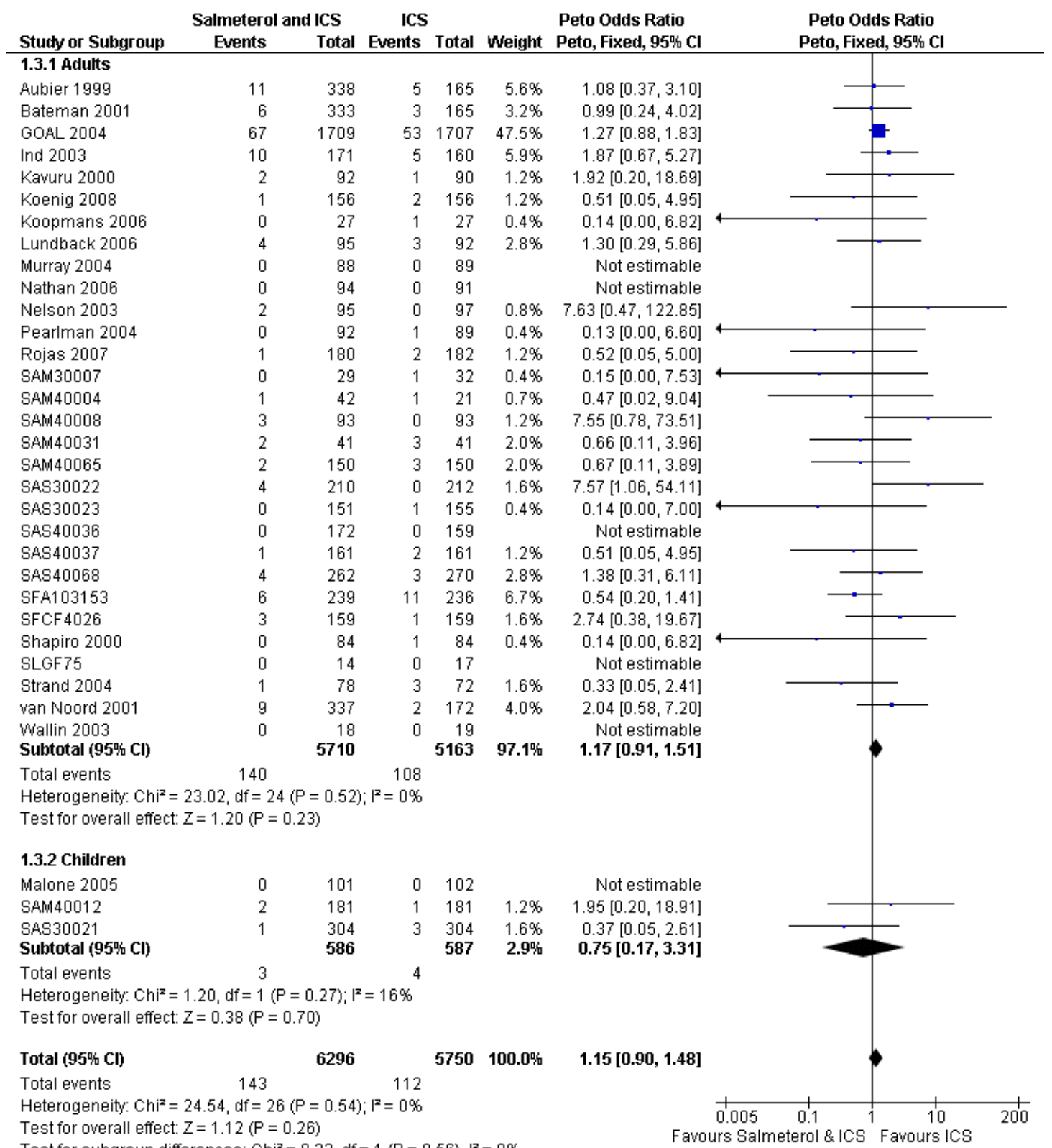




\section{Dose of salmeterol}

The dose of salmeterol used in three studies was less than the usual daily dose of $50 \mathrm{mcg}$ twice daily, so sensitivity analysis was carried out on the primary outcomes excluding these studies (SAS30021; SAS30022; SAS30023). There were no deaths in these studies so mortality results were unaffected. The non-fatal SAE results are shown in Figure 11. The results in adults without these studies in adults (Peto OR 1.15; 95\% CI 0.88 to 1.49 ) are very similar to the full data set, but in children (Peto OR 1.95; 95\% CI 0.20 to 18.91) the confidence interval widens when these studies are excluded. 
Figure I I. Forest plot of comparison: I Regular Salmeterol in addition to regular inhaled corticosteroids, outcome: I.2 All-cause non-fatal SAE (without the lower dose studies)

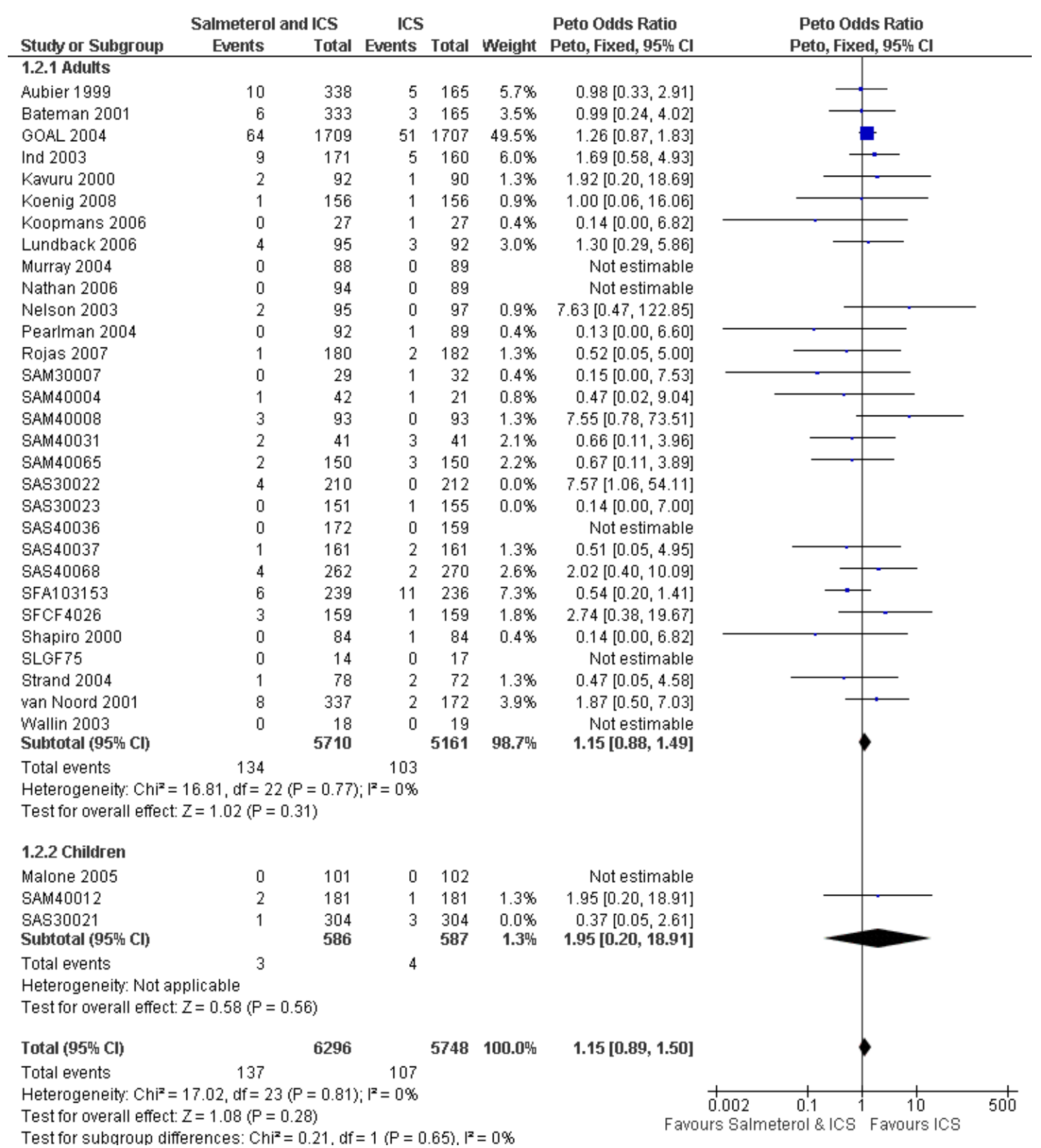




\section{Subgroup Analyses}

Mortality data was too sparse to carry out any sub-group analysis. For non-fatal serious adverse events, tests for interaction between adults and children were all negative, but very few children have been studied, so this result should not be interpreted as excluding important possible differences between adults and children. As only four studies included patients on separate salmeterol and fluticasone inhalers (Aubier 1999 [one of the three study arms]; Ind 2003; SLGF75; Wallin 2003 see Table 1), we did not attempt to make a subgroup comparison between separate and combined inhalers.

\section{DISCUSSION}

\section{Summary of main results}

\section{All cause mortality}

The confidence intervals for all cause mortality in adults and adolescents indicate that for every thousand patients treated with regular salmeterol and inhaled corticosteroids in comparison to the same dose of inhaled corticosteroids are compatible with up to two additional deaths or two less deaths in adults over 31 weeks of treatment, and at most six additional deaths to six less deaths in children over 16 weeks of treatment (the average duration of treatment in the respective trials). The pooled Peto Odds Ratio for adults and adolescents was 1.05 (95\% CI 0.32 to 3.47), and could not be calculated for children as there were no deaths in children.

\section{All cause non fatal serious adverse events}

For non-fatal serious adverse events the limits of the pooled confidence interval are nine more to two fewer adults and adolescents and eight more to ten fewer children for every thousand treated over the period of time represented in the trials. The Peto Odds Ratio was 1.17 (95\% CI 0.90 to 1.52) for adults, and 0.75 (95\% CI 0.17 to 3.31 ) for children.

\section{Overall completeness and applicability of evidence}

Two large surveillance studies have been carried out on the use of regular salmeterol (SMART 2006, SNS 1993) without randomised inhaled corticosteroids. No similar size study has been performed to assess the safety of regular salmeterol randomised with inhaled corticosteroids. The results of this review are therefore less precise than those of the previous review on the safety of regular salmeterol randomised without inhaled corticosteroids (Cates 2008a), and very little data are available from studies on children.

\section{Quality of the evidence}

Risk of bias was assessed as low in the included studies, as the procedures for randomisation and blinding were appropriate having been designed for regulatory purposes (thereby ensuring common definitions of serious adverse events and minimising the likelihood of selection bias, even though this was not well reported in published papers or trial registers).

\section{Potential biases in the review process}

The selection of the best method to combine studies with rare events is contentious when event rates are low, not least because of the corrections required to calculate Odds Ratios with zero events (Sweeting 2004). Since it became apparent in the course of carrying out our reviews that the pooled Odds Ratios were heavily dependent on the zero adjustment used in the MantelHaenszel and Inverse Variance methods, we used the Peto Odds Ratio and Risk Differences to report results of this review. The likely bias in using the Peto Odds Ratio is small as only three trials (Aubier 1999; Bateman 2001; van Noord 2001) had any imbalance in the number of patients in each arm (Sweeting 2004). In these studies twice the number patients were randomised to regular salmeterol with inhaled corticosteroids in comparison to inhaled corticosteroids alone.

Similarly the included studies were influenced by the decision to restrict the review to trials that randomised participants to salmeterol and inhaled corticosteroids, but this decision reduces the risk of bias arising from patients discontinuing their usual inhaled steroid medication if they feel better on the randomised treatment. This presupposes a similar risk of SAEs when salmeterol and fluticasone are delivered via one inhaler, and when salmeterol is added to ICS therapy via a separate inhaler, when both are randomised treatments in a controlled trial.

\section{Agreements and disagreements with other studies or reviews}

Two existing reviews of the use of salmeterol with inhaled corticosteroids have shown similar results to the findings of this reviews. Bateman 2008 concentrated on asthma-related outcomes, 
whilst Jaeschke 2008a considered both salmeterol and formoterol in adults in comparison to the inhaled corticosteroids at the same dose and higher doses. Neither of these reviews showed a significant increase in the risk of serious adverse events, but the results were not precise enough to rule out a clinically important increase or decrease in serious adverse events with regular salmeterol.

It became apparent during the course of preparing this review that there are minor discrepancies between the results recorded in the serious adverse event reports on the GlaxoSmithKline web site and the data used in Bateman 2008 and Jaeschke 2008a. An example of this relates to the death in Aubier 1999, and is related to the question of whether the adverse event was classified as being "on-treatment" (see Aubier Notes in Characteristics of included studies ). Overall the magnitude of these differences is small, and mostly relates to an external review of company data and inclusion of reviewed data in some of the analyses; this has not altered the conclusions of the review.

\section{Administration of inhaled corticosteroids}

There is no clear difference seen between the point estimate and confidence interval of the Odds Ratio for non-fatal serious adverse events found in this review (Peto OR 1.16; 95\% CI 0.90 to 1.50), and those seen in the previous review comparing salmeterol to placebo (Odds Ratio 1.14; 95\% CI 1.01 to 1.28) Cates 2008a. However the average non-fatal serious adverse event rate in the control arms of the trials in this review that included randomised inhaled corticosteroids was $2.0 \%$ over 31 weeks, in comparison to $3.6 \%$ over 28 weeks in SMART 2006 (which accounted for the majority of patients in Cates 2008a).

Combined data from the GSK submission to the FDA (FDA 2008) shows separate outcome data for GSK trials that used inhaled corticosteroids as background treatment, those which randomised patients to inhaled corticosteroids in a separate inhaler and those which randomised patients to a combined salmeterol/ fluticasone inhaler. These results are not directly comparable to those included in this review (as higher doses of inhaled corticosteroids may have been used in the control arms), but the breakdown by inhaled corticosteroid use is shown in Figure 12 and Figure 13. These results demonstrate that there was a significantly higher risk of asthma-related hospitalisation in trials where background inhaled corticosteroids were used, but there was no significant difference in trials which randomised patients to inhaled corticosteroids. However smaller numbers of events in the latter groups resulted in wide confidence intervals, so that an increase in adverse events could not be ruled out in trials that randomised patients to regular inhaled corticosteroids with regular salmeterol.

Figure 12. Risk difference (per 10,000 patients) of asthma-related death by use of Inhaled corticosteroids in GSK meta-analysis of trials of regular salmeterol (from FDA submission 2008)

\section{Meta-Analysis: Risk Difference for Asthma-Related Death (0.5 Continuity Correction)}

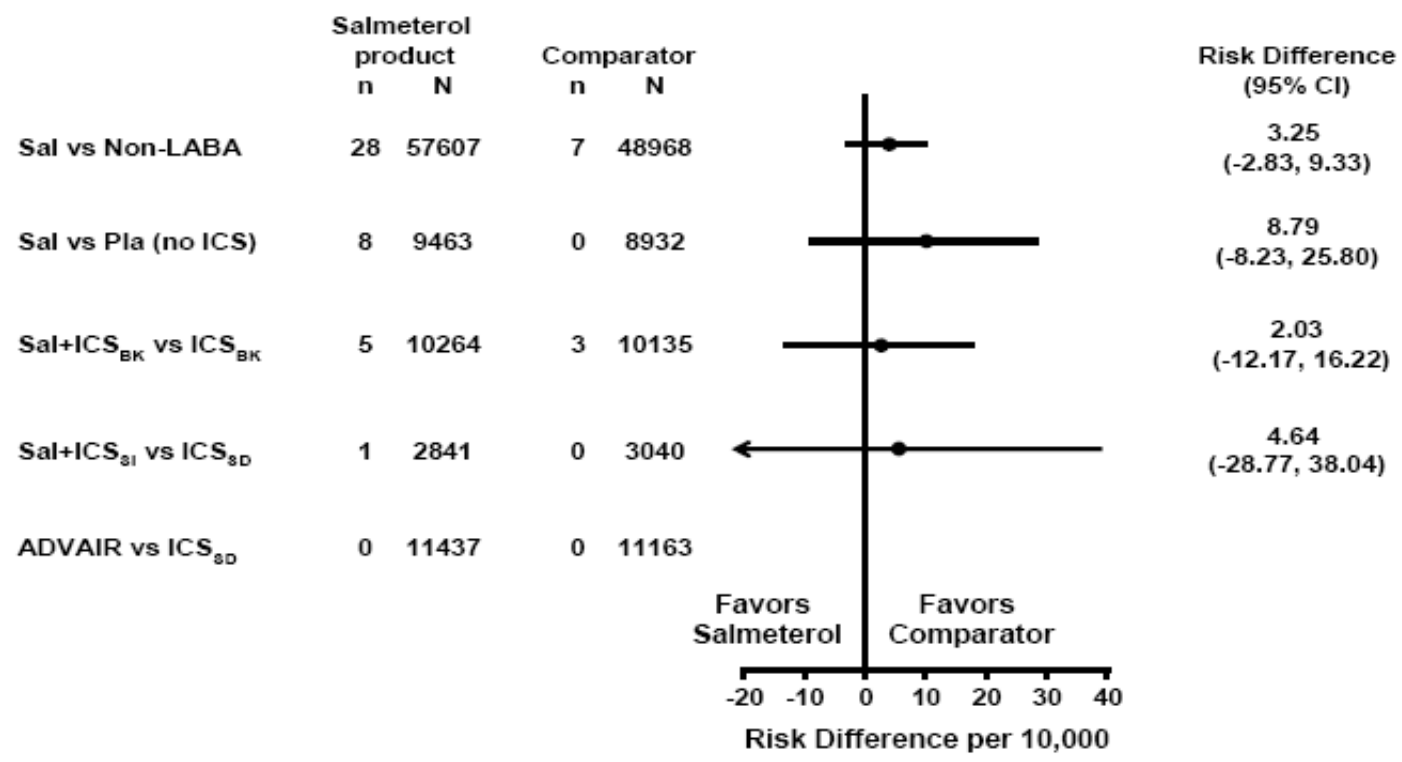

Regular treatment with salmeterol and inhaled steroids for chronic asthma: serious adverse events (Review) 
Figure 13. Risk difference (per 10,000 patients) of asthma-related hospitalisation by use of Inhaled corticosteroids in GSK meta-analysis of trials of regular salmeterol (from FDA submission 2008)

Meta-Analysis: Risk Difference for Asthma-Related Hospitalization (0.5 Continuity Correction)

\begin{tabular}{|c|c|c|c|c|c|c|}
\hline & $\begin{array}{c}\text { Salm } \\
\text { pro } \\
\text { n }\end{array}$ & $\begin{array}{l}\text { eterol } \\
\text { duct } \\
\text { N }\end{array}$ & $\underset{n}{\text { Comp }}$ & $\begin{array}{c}\text { parator } \\
\mathrm{N}\end{array}$ & & $\begin{array}{l}\text { Risk Difference } \\
(95 \% \mathrm{Cl})\end{array}$ \\
\hline Sal vs Non-LABA & 655 & 57607 & 448 & 48968 & & $\begin{array}{c}17.88 \\
(4.50,31.26)\end{array}$ \\
\hline Sal vs Pla (no ICS) & 87 & 9463 & 59 & 8932 & & $\begin{array}{c}26.99 \\
(-2.43,56.40)\end{array}$ \\
\hline Sal+ $+\mathrm{ICS}_{\mathrm{BK}}$ vs ICS $\mathrm{ICK}_{\mathrm{BK}}$ & 198 & 10264 & 151 & 10135 & & $\begin{array}{c}46.02 \\
(8.10,83.93)\end{array}$ \\
\hline Sal+ICS $S_{\mathrm{SI}}$ vs ICS & 16 & 2841 & 14 & 3040 & & $\begin{array}{c}14.48 \\
(-30.83,59.79)\end{array}$ \\
\hline \multirow[t]{2}{*}{ ADVAIR vs ICS $S_{S D}$} & 31 & 11437 & 29 & 11163 & & $\begin{array}{c}0.28 \\
(-18.51,19.06)\end{array}$ \\
\hline & & & & $\begin{array}{c}\text { Favors } \\
\text { Salmeterol }\end{array}$ & $\begin{array}{c}\text { Favors } \\
\text { Comparator }\end{array}$ & \\
\hline
\end{tabular}

It is of interest that the serious adverse event rates in the control arms of these studies are also consistently higher in trials using background inhaled corticosteroids in comparison to those that randomised patients to inhaled corticosteroids. This may reflect a greater asthma severity in those patients who had been started by their own physician on background inhaled corticosteroids (as shown by Sears 2008 in the RELIEF study), but could also be compounded by the known poor adherence to treatment with inhaled corticosteroids in routine practice. This raises uncertainty about the application of the results of patients in clinical trials, which usually include much more intensive monitoring of adherence to therapy. Since we cannot assume that adherence to treatment in trials will be matched in routine practice, care needs to be exercised in both the interpretation and application of the trial results (Weiss 2008).

We were not able to investigate possible difference in trial findings with combined and separate inhalers due to the paucity of patients

on separate inhalers included in the trials in this review (less than 300 patients were randomised to separate fluticasone and salmeterol inhalers, see Table 1).

\section{A U T HOR S' CONCLUSIONS Implications for practice}

No significant differences have been found in fatal or non-fatal serious adverse events in trials in which regular salmeterol has been randomly allocated with inhaled corticosteroids, in comparison to inhaled corticosteroids at the same dose. Although 10,873 adults and 1,173 children have been included in trials, the number of patients suffering adverse events is too small, and the results are too imprecise to confidently rule out a relative increase in all-cause

Regular treatment with salmeterol and inhaled steroids for chronic asthma: serious adverse events (Review) 
mortality or non-fatal adverse events. It is therefore not possible to determine whether the increase in all-cause non-fatal serious adverse events reported in the previous meta-analysis on regular salmeterol alone is abolished by the additional use of inhaled corticosteroids. The absolute difference between groups in the risk of serious adverse events was small. There were no asthma-related deaths and few asthma-related serious adverse events. Clinical decisions and information for patients regarding regular use of salmeterol have to take into account the balance between known symptomatic benefits of salmeterol and the degree of uncertainty and concern associated with its potential harmful effects.

\section{Implications for research}

Studies on children are currently lacking in this area. In order to further quantify the risks of regular salmeterol with inhaled cor- ticosteroids a large-scale surveillance study is required. Future research should clearly specify the number of patients with fatal and non-fatal serious adverse events by treatment group and cause, and outcomes should be verified by an independent outcome panel.

\section{ACKNOWLEDGEMENTS}

We thank Susan Hansen of the Cochrane Airways Group for assistance in searching for trials and obtaining the abstracts and full reports, and extraction of data on trial characteristics. We also acknowledge the assistance of Matthew Cates in relation to the physiology of beta-agonist receptors and co-writing of protocol. We thank Steve Yancey for providing information from data on file at GlaxoSmithKline.

\section{REF ERENCES}

\section{References to studies included in this review}

Aubier 1999 \{published data only\}

SFCB3019. http://ctr.gsk.co.uk/Summary/

fluticasone_salmeterol/III_SFCB3019.pdf Accessed July 2008.

Aubier M, Pieters WR, Schlösser NJ, Steinmetz KO. Salmeterol/fluticasone propionate $(50 / 500 \mathrm{microg})$ in combination in a Diskus inhaler (Seretide) is effective and safe in the treatment of steroid-dependent asthma. Respiratory Medicine 1999;93:876-84.

\section{Bateman 2001 \{published data only\}}

SFCB3022 . http://ctr.gsk.co.uk/Summary/ fluticasone_salmeterol/III_SFCB3022.pdf Accessed July 2008.

* Bateman ED, Silins V, Bogolubov M. Clinical equivalence of salmeterol/fluticasone propionate in combination (50/100 micrograms twice daily) when administered via a chlorofluorocarbon-free metered dose inhaler or dry powder inhaler to patients with mild-to-moderate asthma. Respiratory Medicine 2001;95:136-46.

GOAL 2004 \{published and unpublished data\}

Anonymous. GSK asthma trial suggests total control is possible. Pharmaceutical Journal 2004;273(7322):594. Arthurs R. Gaining optimal asthma control. Practice Nurse 2004;Suppl:3-8.

Bateman E, Boushey H, Bousquet J, Busse W, Clark T, Pauwels R, Pedersen S. Achieving and maintaining guideline defined asthma control with salmeterol/fluticasone propionate versus fluticasone propionate alone: the results of the GOAL study. American Journal of Respiratory and Critical Care Medicine 2004;169(7):A87.

Bateman E, Boushey H, Bousquet J, Busse W, Clark T, Pauwels R, Pederson S. Achievement for guideline based asthma control with salmeterol/fluticasone proprioante comapred with fluticasone proprioante alone; Results of Goal study. Triennial World Asthma Meeting, Thailand (16-19 February). 2004.

Bateman E, Pauwels R, Boushey H, Bousquet J, Busse W, Clark T, Pedersen S. Aiming for total control of asthma significantly improves asthma-related quality of life: salmeterol/fluticasone propionate versus fluticasone propionate alone. Amercian Journal of Respiratory and Critical Care Medicine 2004;169(7):A87.

* Bateman ED, Boushey HA, Bousquet J, Busse WW, Clark TJ, Pauwels RA, Pedersen SE, GOAL Investigators Group. Can guideline-defined asthma control be achieved? The Gaining Optimal Asthma ControL study. American Journal of Respiratory \& Critical Care Medicine 2004;170(8): 836-44.

Bateman ED, Boushey HA, Bousquet J, Busse WW, Clark TJ, Pauwels RA, Pedersen SE, GOAL Investigators Group. Can guideline-defined asthma control be achieved? The Gaining Optimal Asthma ControL study. American Respiratory and Criticial Care Medicine. 2004:Online data supplement.

Bateman ED, Bousquet J, Keech ML, Busse WW, Clark TJ, Pedersen SE. The correlation between asthma control and health status: the GOAL study. European Resspiratory Journal 2006:Epub ahead of print.

Bateman ED, Edin HM, Sondhi S, Gul N. Asthmarelated quality of life in the GOAL study: Baseline results. European Respiratory Journal 2002;20(Suppl 38):46s. Bons J, Cordier JF, Godard P, Prud'Homme A, Celli I, Bousquet J. Aiming for total control of asthma: the GOAL study design. Revue Française d'Allergologie et d'Immunologie Clinique 2004;44(367):TT13.

Boushey H, Bateman E, Bousquet J, Busse W, Clark T, Pauwels R, Pedersen S. Improvements in asthma outcomes following 1 year of treatment with salmeterol/ 
fluticasone or fluticasone alone when stepped up to achieve guideline-defined total control. Journal Allergy and Clinical Immunology 2004;113(2 (suppl 1)):114s-5s.

Boushey H, Bateman E, Bousquet J, Busse W, Clark T, Pauwels R, Pederson S. Achieving total control of asthma with salmeterol/fluticasone propionate versus fluticasone propionate alone: Goal study results. Triennial World Asthma Meeting, Thailand (16-19 February). 2004. Boushey HA, Pedersen S, Bateman E, Clark T, Busse W, Bousquet J, Pauwels R. Improved exacerbation rates and asthma control in current and former smokers treated with salmeterol/fluticasone propionate: results of the GOAL study. Journal of Allergy \& Clinical Immunology 2005;115 (Suppl 2):S59.

Bousquet J. Is asthma control achievable?. European Respiratory Review 2004;13(92):102-4.

Bousquet J, Bateman E, Boushey H, Busse W, Clark T, Pauwels R, Pedersen S. The effect of oral corticosteroids and high-dose combination therapy on achieving control of refractory asthma. Journal Allergy and Clinical Immunology 2004;113(2 (suppl 1)):113s.

Bousquet J, Bons J, Godard P, Cordier JF, Desfougeres JL, Prud'Homme A. Aiming for total control of asthma: the GOAL study results. Revue Française d'Allergologie et d'Immunologie Clinique 2004;44(367):TT16.

Briggs AH, Bousquet J, Wallace MV, Busse WW, Clark TJH, Pedersen SE, Bateman ED. Cost-effectiveness of asthma control: An economic appraisal of the GOAL study. Allergy 2006;61(5):531-6.

Busse W, Bateman E, Boushey H, Bousquet J, Clark T, Pauwels R, Pedersen S. Achieving GINA/NIH guidelinebased asthma control with salmeterol/fluticasone compared with fluticasone alone: the results of the GOAL study. Journal of Allergy and Clinical Immunology 2004;113(2 (suppl 1)):114s.

Busse W, Bateman E, Boushey H, Bousquet J, Clark T, Pauwels R, Pederson S. Aiming to achieve total control of asthma with salmeterol/luticaosne proprioante and flutiasone proprioante alone is well tolerated: Goal 1 year safety data. Triennial World Asthma Meeting, Thailand (16-19 February). 2004.

Clark T, Bateman E, Boushey H, Bousquet J, Busse W, Pauwels R, Pedersen S. Salmeterol/fluticasone and fluticasone alone are well tolerated over 1 year of treatment stepped-up to achieve total control: safety results of the GOAL study. Journal Allergy and Clinical Immunology 2004;113(2 (suppl 1)):115s.

Clark T, Bateman E, Boushey H, Bousquet J, Busse W, Pauwels R, Pedersen S. Time course of achievement of individual clinical goals of asthma treatment: the results of the GOAL study. Amercian Journal of Respiratory and Critical Care Medicine 2004;169(7):A318.

Clark TJ, Bousquet J, Bateman ED, James MH. GOAL (gaining optimal asthma control): a study to assess asthma control. European Respiratory Journal 2001;18(Suppl 33): 175-6s.

Clark TJH, Bateman ED, James MH, on behalf of the
GOAL Steering Committee. Assessing asthma control using a composite measure based on GINA/NIH guidelines: an analysis of GOAL baseline data. European Respiratory Journal 2002;20(Suppl 38):47s.

Clark TJH, Bateman ED on behalf of the GOAL Steering Committee. Aiming for Total Control of asthma in ICSfree patients improves traditional outcomes: Results of the Gaining Optimal Asthma controL (GOAL) study [abstract]. 23rd European Academy of Allergology and Clinical Immunology Meeting Abstract Book. June 12-16. Amsterdam, The Netherlands. 2004; Vol. 204:669. Cordier JF, Bousquet J, Boucot I, Prud'Homme A, Godard P. Which dose for achieving total control of asthma? The results of the GOAL study. Revue Française d'Allergologie et d'Immunologie Clinique 2004;44(367):TT14.

Godard P, Prud'Homme A, Cordier JF, Sohier B, Bousquet J. Time course of achievement of asthma control: The results of the GOAL study. Revue Française d'Allergologie et d'Immunologie Clinique 2004;44(367):TT15.

Juniper EF, Bateman ED, Sondhi S, Gul N. Asthma Control Questionnaire (ACQ) differentiates between levels of clinical control in a large scale trial. Amercian Journal of Respiratory and Critical Care Medicine 2003;167(7):A37. Pauwels R, Bateman E, Boushey H, Bousquet J, Busse W, Clark T, Pedersen S. Addition of oral corticosteroids to combination therapy has little impact on achieving total control of asthma.. 4th Triennial World Asthma Meeting Abstract Book, Bangkok, Thailand, February 16-19. 2004: 135 .

Pauwels R, Bateman E, Boushey H, Bousquet J, Busse W, Clark T, Pedersen S. Aiming for total control of asthma reduces the risk of exacerbations: a comparison of salmeterol/fluticasone propionate versus fluticasone propionate alone. American Journal of Respiratory and Critical Care Medicine 2004;169(7):A87.

Pauwels R, Bateman E, Boushey H, Bousquet J, Busse W, Clark T, Pedersen S. Can total control of asthma be achieved?: the results of the GOAL study. Journal of Allergy and Clinical Immunology 2004;113(2 (suppl 1)):114s.

Pedersen SE. Is guideline-defined asthma control achievable? The Gaining Optimal Asthma ControL (GOAL) Study [Er guideline-defineret astmakontrol opnaelig?]. Ugeskrift for Laeger 2005;167(38):3595-7.

Pedersen SE, Bateman ED on behalf of the GOAL Steering Committee. Aiming for Total Control of asthma in patients taking inhaled corticosteroids improves traditional outcomes: Results of the Gaining Optimal Asthma controL (GOAL) study. [abstract]. 3rd European Academy of Allergology and Clinical Immunology Meeting Abstract Book. June 12-16. Amsterdam, The Netherlands. 2004; Vol. 204:670.

Pederson S, Bateman E, Boushey H, Bousquet J, Busse W, Clark T, Pauwels R. Aiming for guideline defined total control of asthma improves one-year asthma outcomes: Results of Goal study. Triennial World Asthma Meeting, Thailand (16-19 February). 2004.

SAM40027. Gaining Optimal Asthma ControL (GOAL): 
A multi-centre, stratified, randomised, double-blind, parallel-group, step-up comparison of the level of asthma control achieved with salmeterol/fluticasone propionate combination DISKUS (ACCUHALER) dry powder inhaler compared with fluticasone propionate DISKUS (ACCUHALER) alone in adults and adolescents. http:// www.ctr.gsk.co.uk 2004.

\section{Ind 2003 \{published data only\}}

SLGQ97 (SLGB4010). http://ctr.gsk.co.uk/Summary/ salmeterol/IV_SLGB4010.pdf Accessed July 2008. Ind PW, Dal Negro R, Colman NC, Fletcher CP, Browning $\mathrm{D}$, James $\mathrm{MH}$. Addition of salmeterol to fluticasone propionate treatment in moderate-to-severe asthma. Respiratory Medicine 2003;97:555-62.

Kavuru 2000 \{published data only\}

SFCA3002. http://ctr.gsk.co.uk/Summary/

fluticasone_salmeterol/III_SFCA3002.pdf Accessed July 2008.

* Kavuru M, Melamed J, Gross G, LaForce C, House K, Prillaman B, et al.Salmeterol and fluticasone propionate combined in a new powder inhalation device for the treatment of asthma: a randomized, double-blind, placebocontrolled trial. J Allergy Clin Immunol 2000;150(6): 1108-16.

Koenig 2008 \{published data only\}

SAM40086. http://ctr.gsk.co.uk/Summary/ fluticasone_salmeterol/IV_SAM40086.pdf Accessed July 31 2008.

Koenig SM, Murray JJ, Wolfe J, Andersen L, Yancey S, Prillaman B, et al.Does measuring BHR add to guideline derived clinical measures in determining treatment for patients with persistent asthma?. Respiratory Medicine 2008; 102: 665-73.

Koopmans 2006 \{published data only\}

SAS30013. http://ctr.gsk.co.uk/Summary/

fluticasone_salmeterol/IV_SAS30013.pdf accessed August 112008

Koopmans JG, Lutter R, Jansen HM, van der Zee JS. Adding salmeterol to an inhaled corticosteroid: long term effects on bronchial inflammation in asthma. Thorax 2006; 61:306-12.

Lundback 2006 \{published data only\}

FAS40008. http://ctr.gsk.co.uk/Summary/

fluticasone_salmeterol/IV_FAS40008_1y.pdf accessed

August 11th 2008.

Lundbäck B, Rönmark E, Lindberg A, Jonsson AC, Larsson LG, Pétavy F, et al.Control of mild to moderate asthma over 1-year with the combination of salmeterol and fluticasone propionate. Respiratory Medicine 2006;100:2-10.

\section{Malone 2005 \{published data only\}}

SAS30031. http://ctr.gsk.co.uk/Summary/ fluticasone_salmeterol/III_SAS30031.pdf Accessed July 2008 .

* Malone R, LaForce C, Nimmagadda S, Schoaf L, House $\mathrm{K}$, Ellsworth A, et al.The safety of twice-daily treatment with fluticasone propionate and salmeterol in pediatric patients with persistent asthma. Ann Allergy Asthma Immunol 2005;96:66-71.

Murray 2004 \{published data only\}

SAS30017. http://ctr.gsk.co.uk/Summary/

fluticasone_salmeterol/III_SAS30017.pdf Accessed July 2008

* Murray J, Rosenthal R, Somerville L, Blake K, House K, Baitinger $\mathrm{L}$, et al.Fluticasone propionate and salmeterol administered via Diskus compared with salmeterol or fluticasone propionate alone in patients suboptimally controlled with short-acting beta2-agonists. Ann Allergy Asthma Immunol. 2004;93:351-9 2004;93:351-9.

Nathan 2006 \{published and unpublished data\} Edin HM, Payne E, Herrle MR, Schoaf L, Mather DB, Scott $\mathrm{CA}$, et al.Salmeterol/fluticasone propionate combination via HFA MDI improves quality of life. Journal of Allergy \& Clinical Immunology 2001;107(2):S246.

Nathan RA, Mitchell D, Condemi J, Heller A, Schoaf L, Herrle M, et al.Cardiovascular and hypothalmic-pituitaryadrenal axis safety of fluticasone propionate/salmeterol HFA MDI in adolescent and adult patients with asthma. American Journal for Respiratory and Critical Care Medicine 2001;163(5):A863.

* Nathan RA, Rooklin A, Schoaf L, Scott C, Ellsworth A, House K, Dorinsky P. Efficacy and tolerability of fluticasone propionate/salmeterol administered twice daily via hydrofluoroalkane 134 a metered-dose inhaler in adolescent and adult patients with persistent asthma: a randomized, double-blind, placebo-controlled, 12-week study. Clinical therapeutics 2006;28(1):73-85.

Pearlman DS, Kent E, Lanz MJ, Peden D, Baitinger L, Herrle M, et al.Fluticasone propionate/salmeterol HFA MDI has a rapid onset of effect in asthmatics treated with short or long-acting beta-agonists (BA) or inhaled corticosteroids (ICS). Amercian Journal of Respiratory and Critical Care Medicine 2001;163(5):A865.

Rooklin A, Elkayam D, Weiler J, Windom H, Schoaf L, Scott C, et al. The fluticasone propionate/salmeterol HFA MDI is significantly more efficacious in treating asthma than placebo HFA MDI, fluticasone propionate CFC MDI or salmeterol CFC MDI. Journal of Allergy and Clinicial Immunology 2001;107(2):100s.

SAS30004. A randomized, double-blind, placebocontrolled, parallel-group 12-week trial evaluating the safety and efficacy of the salmeterol/fluticasone propionate combination in GR106642X MDI, 50/250mcg BID, and salmeterol in propellant $11 / 12 \mathrm{MDI}, 50 \mathrm{mcg}$ BID, fluticasone propionate in propellant $11 / 12 \mathrm{MDI}, 250 \mathrm{mcg}$ BID, and placebo propellant GR106642X MDI in adult and adolescent subjects with asthma. http://ctr.gsk.co.uk 2005.

Nelson 2003 \{published data only\}

SAS30001. http://ctr.gsk.co.uk/Summary/ fluticasone_salmeterol/III_SAS30001.pdf Accessed July 2008.

* Nelson HS, Wolfe JD, Gross G, Greos LS, Baitinger L, Scott C, Dorinsky P. Efficacy and safety of fluticasone 
propionate $44 \mathrm{mcg} / \mathrm{salmeterol} 21 \mathrm{mcg}$ administered in a hydrofluoroalkane (HFA) metered dose inhaler as an initial asthma maintenance treatment. Ann Allergy Asthma Immunol 2003;91:263-9.

\section{Pearlman 2004 \{published and unpublished data\}}

* Pearlman DS, Peden D, Condemi JJ, Weinstein S, White $\mathrm{M}$, Baitinger L, et al.Efficacy and safety of fluticasone propionate/salmeterol HFA 134A MDI in patients with mild-to-moderate persistent asthma. Journal of Asthma 2004;41(8):797-806.

SAS30003. A stratified, randomised, double-blind, placebo-controlled, parallel-group, 12-week trial evaluating the safety and efficacy of the salmeterol/fluticasone propionate combination in HFA $134 \mathrm{a}$ MDI, $42 / 88 \mathrm{mcg}$ $\mathrm{BID}$, and salmeterol in propellant $11 / 12 \mathrm{MDI}, 42 \mathrm{mcg}$ BID, fluticasone propionate in propellant $11 / 12 \mathrm{MDI}, 88 \mathrm{mcg}$ BID, and placebo propellant HFA 134a MDI in adult and adolescent subjects with asthma. http://ctr.gsk.co.uk 2005. Weinstein SF, Pearlman DS, Condemi JJ, Herrle MR, Scott CA, Payne JE, et al.Superior efficacy of the fluticasone propionate/salmeterol $88 / 42 \mathrm{mcg}$ HFA-MDI combination product versus the individual components in asthmatics previously treated with either short- or long-acting beta2agonists or inhaled corticosteroids. Journal of Allergy \& Clinial Immunology 2001;107(2):S102.

\section{Rojas 2007 \{published data only\}}

SAS30039. http://ctr.gsk.co.uk/Summary/ fluticasone_salmeterol/III_SAS30039.pdf Accessed July 2008.

Barnes N, Rojas R, Palga I, Goldfrad C, Duggan M. Efficacy and safety of fluticasone propionate/salmeterol (250/50ug bd) in a single diskus device compared with fluticasone propionate diskus alone (250ug) as initial maintenance therapy in moderate asthma [Abstract]. American Thoracic Society 2005 International Conference; May 20-25; San Diego, California. 2005:[B35] [Poster: G13].

* Rojas RA, Paluga I, Goldfrad CH, Duggan MT, Barnes $\mathrm{N}$. Initiation of maintenance therapy with salmeterol/ fluticasone propionate combination therapy in moderate asthma: a comparison with fluticasone propionate. $J$ Asthma 2007;44:437-41.

SAM30007 \{published data only\} SAM30007. http://ctr.gsk.co.uk/Summary/ fluticasone_salmeterol/IV_SAM30007.pdf.

\section{SAM40004 \{published data only\}}

* SAM40004. http://ctr.gsk.co.uk/Summary/ fluticasone_salmeterol/IV_SAM40004.pdf accessed August 192008 .

SAM40008 \{published data only\} SAM40008. http://ctr.gsk.co.uk/Summary/ fluticasone_salmeterol/IV_SAM40008.pdf.

SAM40012 \{unpublished data only\} SAM40012. http://ctr.gsk.co.uk/Summary/ fluticasone_salmeterol/IV_SAM40012.pdf.
SAM40031 \{published data only\}

SAM40031. http://ctr.gsk.co.uk/Summary/

fluticasone_salmeterol/IV_SAM40031.pdf.

\section{SAM40065 \{published data only\}}

SAM40065. http://ctr.gsk.co.uk/Summary/

fluticasone_salmeterol/IV_SAM40065.pdf accessed august 11 th 2008 .

SAS30021 \{published data only\}

SAS30021. http://ctr.gsk.co.uk/Summary/ fluticasone_salmeterol/III_SAS30021.pdf accessed August 11 th 2008.

SAS30022 \{unpublished data only\}

SAS30022. http://ctr.gsk.co.uk/Summary/

fluticasone_salmeterol/III_SAS30022.pdf Accessed July 2008.

Kerwin EM, Nathan RA, Meltzer EO, Ortega HG, Yancey SW, Schoaf L, et al.Efficacy and safety of fluticasone propionate/salmeterol 250/50 mcg Diskus administered once daily. Respir Med. 2008/01/22 2008; Vol. 102, issue 4:495-504. [0954-6111: (Print)]

\section{SAS30023 \{published data only\}}

SAS30023. http://ctr.gsk.co.uk/Summary/

fluticasone_salmeterol/III_SAS30023.pdf accessed August 112008.

Boonsawat W, Goryachkina L, Millns H, Balsara S. The efficacy and safety of seretide/advair once daily (50/100 $\mathrm{mcg}$ ) compared with fluticasone propionate $(100 \mathrm{mcg})$ once daily and placebo as initial maintainence therapy in mild asthma [Abstract]. American Thoracic Society 100th International Conference, May 21-26, 2004, Orlando 2004:A37 Poster J82.

\section{SAS40036 \{published data only\}}

SAS40036. http://ctr.gsk.co.uk/Summary/

fluticasone_salmeterol/IV_SAS40036.pdf accessed August 11 th 2008.

SAS40037 \{published data only\}

SAS40037. http://ctr.gsk.co.uk/Summary/

fluticasone_salmeterol/IV_SAS40037.pdf accessed August 112008.

SAS40068 \{published data only\}

SAS40068. http://ctr.gsk.co.uk/Summary/

fluticasone_salmeterol/IV_SAS40068.pdf Accessed August 112008.

SFA103153 \{unpublished data only\}

SFA103153. http://ctr.gsk.co.uk/Summary/ fluticasone_salmeterol/IV_SFA103153.pdf Accessed July 2008.

Bailey W, Castro M, Matz J, White M, et al.Asthma exacerbations in African Americans treated for 1 year with combination fluticasone proprionate and salmeterol or fluticasone proprionate alone. Current Medical Research and Opinions 2008;24(6):1669-82.

SFCF4026 \{published data only\}

SFCF4026. http://ctr.gsk.co.uk/Summary/ fluticasone_salmeterol/IV_SFCF4026.pdf Accessed August 112008. 
Shapiro 2000 \{published data only\}

SFCA3003. A Randomized, Double-Blind, Parallel-Group Trial Evaluating Safety and Efficacy of Salmeterol $50 \mathrm{mcg}$ BID and Fluticasone Propionate $250 \mathrm{mcg}$ BID Individually and in Combination and Placebo in Subjects with Asthma. http://ctr.gsk.co.uk/Summary/fluticasone_salmeterol/ III_SFCA3003.pdf 2005.

Shapiro G, Lumry W, Wolfe J, Given J, White M, Woodring A, et al.Combined salmeterol $50 \mathrm{mcg}$ and fluticasone propionate $250 \mathrm{mcg}$ in the diskus device for the treatment of asthma. American Journal of Respiratory and Critical Care Medicine 2000;161:527-34.

\section{SLGF75 \{published data only\}}

SLGF75. http://ctr.gsk.co.uk/Summary/

fluticasone_propionate/IV_SLGF75.pdf Accessed August 11 th 2008.

Strand 2004 \{published data only\}

SAM40049. http://ctr.gsk.co.uk/Summary/

fluticasone_salmeterol/IV_SAM40049.pdf Accessed July 2008.

Strand AM, Luckow A. Initiation of maintenance treatment of persistent asthma: salmeterol/fluticasone propionate combination treatment is more effective than inhaled steroid alone. Respiratory Medicine 2004;98:1008-15.

van Noord 2001 \{published data only\}

SFCB3023. http://ctr.glaxowellcome.co.uk/Summary/ fluticasone_salmeterol/III_SFCB3023.pdf Accessed July 2008.

* van Noord JA, Lill H, Carrillo Diaz C, Greefhorst AP, Davies P. Clinical equivalence of a salmeterol/fluticasone propionate combination product $(50 / 500 \mathrm{mcg})$ delivered via a chlorofluorocarbon-free metered-dose inhaler with the Diskus $^{T M}$ in patients with moderate to severe asthma. Clin Drug Investig 2001;21:243-255. 2001;21:243-55.

Wallin 2003 \{published data only\}

SLGQ98. http://ctr.gsk.co.uk/Summary/salmeterol/ IV_SLGQ98.pdf Accessed July 2008.

Wallin A, Sue-Chu M, Bjermer L, Ward J, Sandström T, Lindberg A, et al.Effect of inhaled fluticasone with and without salmeterol on airway inflammation in asthma. $J$ Allergy Clin Immunol 2003;112:72-8.

\section{References to studies excluded from this review}

\section{Adinoff 1998 \{published data only\}}

Adinoff AD, Schwartz HJ, Rickard KA, Yancey SW, Swearingen BE. Salmeterol compared with current therapies in chronic asthma. [erratum appears in J Fam Pract 1999 Jan;48(1):67]. Journal of Family Practice 1998; Vol. 47, issue 4:278-84.

\section{Adolfsson 2005 \{published data only\}}

Adolfsson LE, Lundgren M, Tilling B, Jern S, Tyren C, Godwood A, et al.Short-term safety and tolerability of double-dose salmeterol/fluticasone propionate in adult asthmatic patients. Clinical Drug Investigation 2005; Vol. 25 , issue 4:231-41.

\section{Bateman 1998 \{published data only\}}

Bateman ED, Britton M, Carrillo J, Almeida J, Wixon C. Salmeterol/fluticasone combination inhaler. A new, effective and well tolerated treatment for asthma. Clinical Drug Investigation 1998; Vol. 16, issue 3:193-201.

\section{Bateman 2006 \{published data only\}}

Bateman ED, Jacques L, Goldfrad C, Atienza T, Mihaescu T, Duggan M. Asthma control can be maintained when fluticasone propionate/salmeterol in a single inhaler is stepped down. Journal of Allergy \& Clinical Immunology 2006; Vol. 117, issue 3:563-70.

\section{Baumgarten 2002 \{published data only\}} Baumgarten C, Geldszus R, Behre U, Peslis N, Trautmann $\mathrm{M}$. Initial treatment of symptomatic mild to moderate bronchial asthma with the salmeterol/fluticasone propionate (50/250 microg) combination product (SAS 40023). Eur J Med Res 2002; Vol. 7, issue 1:1-7.

\section{Bergmann 2004 \{published data only\}}

Bergmann KC, Lindemann L, Braun R, Steinkamp G. Salmeterol/fluticasone propionate (50/250 microg) combination is superior to double dose fluticasone (500 microg) for the treatment of symptomatic moderate asthma. Swiss Medical Weekly 2004; Vol. 134, issue 3-4:50-8.

\section{Bjermer 2000 \{published data only\}}

Bjermer L, Bisgaard H, Bousquet J, Fabbri LM, Greening A, Haahtela T, et al.Montelukast or salmeterol combined with an inhaled steroid in adult asthma: design and rationale of a randomized, double-blind comparative study the IMPACT Investigation of Montelukast as a Partner Agent for Complementary Therapy-trial. Respiratory Medicine 2000; Vol. 94, issue 6:612-21.

Bjermer 2003 \{published data only\} Bjermer L, Bisgaard H, Bousquet J, Fabbri LM, Greening AP, Haahtela T, et al.Montelukast and fluticasone compared with salmeterol and fluticasone in protecting against asthma exacerbation in adults: one year, double blind, randomised, comparative trial. BMJ 2003; Vol. 327, issue 7420:891.

Bleecker 2006 \{published data only\}

Bleecker ER, Yancey SW, Baitinger LA, Edwards LD, Klotsman M, Anderson WH, et al.Salmeterol response is not affected by beta2-adrenergic receptor genotype in subjects with persistent asthma. Journal of Allergy \& Clinical Immunology 2006; Vol. 118, issue 4:809-16.

\section{Bleecker 2007 \{published data only\}} Bleecker E, Yancey S, Ortega H, Anderson W. Arginine 16 genotype does not modulate clinical response to salmeterol in subjects with asthma. Chest 2007; Vol. 132, issue 4:436.

\section{Bleecker 2008 \{published data only\}}

Bleecker ER, Postma DS, Lawrance RM, Meyers DA, Ambrose HJ, Goldman M. Effect of ADRB2 polymorphisms on response to long-acting beta2-agonist therapy: a pharmacogenetic analysis of two randomised studies.[see comment]. [Review] [33 refs] Comment in: Lancet. 2008 Dec 22;370(9605):2075-6; PMID: 18156014. LANCET 2008; Vol. 370, issue 9605:2118-25. 
Bracamonte 2005 \{published data only\}

Bracamonte T, Schauer U, Emeryk A, Godwood A, Balsara S. Efficacy and safety of salmeterol/fluticasone propionate combination delivered by the Diskus or pressurised metered-dose inhaler in children with asthma. Clinical Drug Investigation 2005; Vol. 25, issue 1:1-11.

\section{Busse 2006 \{published data only\}}

Busse W. The effect of salmeterol on eosinophil function. clinicaltrials.gov 2006.

\section{Calhoun 2001 \{published data only\}} Calhoun WJ, Nelson HS, Nathan RA, Pepsin PJ, Kalberg $\mathrm{C}$, Emmett A, et al.Comparison of fluticasone propionatesalmeterol combination therapy and montelukast in patients who are symptomatic on short-acting beta2-agonists alone. American Journal of Respiratory \& Critical Care Medicine 2001; Vol. 164, issue 5:759-63.

\section{Chapman 1999 \{published data only\}} Chapman KR, Ringdal N, Backer V, Palmqvist M, Saarelainen S, Briggs M. Salmeterol and fluticasone propionate 50/250 mug administered via combination Diskus inhaler: As effective as when given via separate Diskus inhalers. Canadian Respiratory Journal 1999; Vol. 6 , issue $1: 45-51$.

Condemi 1999 \{published data only\} Condemi JJ, Goldstein S, Kalberg C, Yancey S, Emmett A, Rickard K. The addition of salmeterol to fluticasone propionate versus increasing the dose of fluticasone propionate in patients with persistent asthma. Salmeterol Study Group. Annals of Allergy, Asthma, \& Immunology 1999; Vol. 82, issue 4:383-9.

\section{Cook 1998 \{published data only\}}

Cook D, Srebro SH, Rogenes PR, Rickard K, Edwards L, Johnson MC. A comparison of the safety and efficacy of fluticasone, triamcinolone, and fluticasone plus salmeterol in patients with mild to moderate asthma [abstract]. American Journal of Respiratory and Critical Care Medicine 1998; Vol. 157, issue 3 Suppl:A416.

\section{D’Urzo 2001 \{published data only\}} D'Urzo AD, Chapman KR, Cartier A, Hargreave FE, Fitzgerald M, Tesarowski D. Effectiveness and safety of salmeterol in non-specialist practice settings. Chest 2001; Vol. 119, issue 3:714-9.

\section{Del 2001 \{published data only\}}

Del Rio-Navarro BE, Sienra-Monge JJL, Alvarez-Amador M, Reyes-Ruiz N, Arevalo-Salas A, Berber A. Serum potassium levels, CPK-MB and ECG in children suffering asthma treated with beclomethasone or beclomethasonesalmeterol. Allergologia et Immunopathologia 2001; Vol. 29, issue 1:16-21.

\section{Deykin 2007 \{published data only\}}

Deykin A, Wechsler ME, Boushey HA, Chinchilli VM, Kunselman SJ, Craig TJ, et al.Combination therapy with a long-acting beta-agonist and a leukotriene antagonist in moderate asthma. American Journal of Respiratory \& Critical Care Medicine 2007; Vol. 175, issue 3:228-34.

\section{Didier 1997 \{published data only\}}

Didier A, Campos OR. A two-month comparison of salmeterol/beclomethasone and slow-release terbutaline/ budesonide in moderate asthma management. Clinical Drug Investigation 1997; Vol. 14, issue 1:1-11.

Dorinsky 2004 \{published data only\} Dorinsky P, Kerwin E, Schoaf L, Ellsworth A, Housse K. Effectiveness and safety of fluticasone propionate / salmeterol $250 / 50 \mathrm{mcg}$ administered once daily to patients with persistent asthma [Abstract]. European Respiratory Journal 2004; Vol. 24, issue Suppl 48:309s.

\section{Faurschou 1994 \{published data only\}} Faurschou P, Engel AM, Haanaes OC. Salmeterol in two different doses in the treatment of nocturnal bronchial asthma poorly controlled by other therapies. Allergy 1994; Vol. 49, issue 10:827-32.

Fish 2001 \{published data only\} Fish JE, Israel E, Murray JJ, Emmett A, Boone R, Yancey SW, et al.Salmeterol Powder Provides Significantly Better Benefit Than Montelukast in Asthmatic Patients Receiving Concomitant Inhaled Corticosteroid Therapy. Chest 2001; Vol. 120, issue 2:423-30.

Fujimoto 2006 \{published data only\} Fujimoto K, Komatsu Y, Yasuo M, Urushihata K, Kubo $\mathrm{K}$. Comparison of the clinical efficacy of salmeterol and sustained-release tulobuterol (patch) on inadequately controlled asthma patients on inhaled corticosteroids. Journal of Asthma. 2006; Vol. 43, issue 7:501-7.

\section{GlaxoSmithKline 2004 \{published data only\}}

GlaxoSmithKline. A 52-week multicentre, randomised, double-blind, double dummy, placebo-controlled parallel group study to compare the efficacy and tolerability of salmeterol/fluticasone propionate combination (SERETIDE/VIANI/ADVAIR) 50/100 mcg once daily in the morning with fluticasone propionate (FLIXOTIDE/ FLOVENT) $100 \mathrm{mcg}$ twice daily and placebo twice daily, all via the DISKUS/ACUHALER as initial maintenance therapy in mild asthmatic subjects. GlaxoSmithKline Clinical Trial Register 2004.

GlaxoSmithKline 2005 \{published data only\} GlaxoSmithKline. A 12 week, randomized, double-blind, parallel group study to compare the efficacy and safety of salmeterol/fluticasone propionate/GR106642X (25/50 $\mu \mathrm{g}$ $\mathrm{x} 2$ inhalations) bid with fluticasone propionate $(125 \mu \mathrm{g} \mathrm{x}$ 2 inhalations) bid in adolescent and adult patients with mild to moderate asthma. GlaxoSmithKline Clinical Trial Register 2005.

\section{GlaxoSmithKline 2005a \{published data only\}}

GlaxoSmithKline. Comparison of the efficacy and safety of Seretide and beclomethasone dipropionate plus montelukast in asthma. GlaxoSmithKline Clinical Trial Register 2005.

\section{GlaxoSmithKline 2005c \{published data only\}} GlaxoSmithKline. A multi-centre, randomised, open-label, parallel group clinical trial to assess the efficacy and safety of salmeterol/fluticasone propionate combination product 
( 2 x 25/125 $\mu$ g/actuation, bd) via a hydrofluoroalkane metered-dose inhaler compared with salmeterol/fluticasone propionate accuhaler $(50 / 250 \mu \mathrm{g}$ bd) in adult Chinese patients with mild to moderate asthma. GlaxoSmithKline Clinical Trial Register 2005.

\section{GlaxoSmithKline 2005d \{published data only\}}

GlaxoSmithKline. A randomized, double-blind clinical tria comparing the efficacy and safety of salmeterol xinafoate $42 \mathrm{mcg}$ bid plus fluticasone propionate $88 \mathrm{mcg}$ bid versus fluticasone propionate $220 \mathrm{mcg}$ bid alone in subjects with asthma not well controlled on fluticasone propionate $88 \mathrm{mcg}$ bid. GlaxoSmithKline Clinical Trial Register 2005.

\section{GlaxoSmithKline 2005e \{published data only\}}

GlaxoSmithKline. A repeat dose, randomised, double blind, two-way crossover study to assess the safety and systemic exposure of an investigational formulation compared to concurrent administration of individual fluticasone propionate 50 and salmeterol 50 DISKUS inhalers in subjects aged 18-55 years with mild asthma. GlaxoSmithKline Clinical Trial Register 2005.

\section{Greening 1994 \{published data only\}}

Greening AP, Ind PW, Northfield M, Shaw G. Added salmeterol versus higher-dose corticosteroid in asthma patients with symptoms on existing inhaled corticosteroid. Allen \& Hanburys Limited UK Study Group. Lancet 1994; Vol. 344, issue 8917:219-24.

\section{Grutters 1999 \{published data only\}}

Grutters JC, Brinkman L, Aslander MM, van den Bosch JM, Koenderman L, Lammers JW. Asthma therapy modulates priming-associated blood eosinophil responsiveness in allergic asthmatics. European Respiratory Journal 1999; Vol. 14, issue 4:915-22.

\section{House 2004 \{published data only\}}

House K, Dorinsky PM, Stauffer J, Schoaf L, Ellsworth A. The Safety of Fluticasone propionate/Salmeterol Diskus(R) in Pediatric Patients Ages 4 -11 with Asthma [Abstract]. Chest 2004; Vol. 126, issue 4 Suppl:911S-a.

Ilowite 2004 \{published data only\}

Ilowite J, Webb R, Friedman B, Kerwin E, Bird SR, Hustad CM, et al.Addition of montelukast or salmeterol to fluticasone for protection against asthma attacks: a randomized, double-blind, multicenter study. Annals of Allergy, Asthma, \& Immunology 2004; Vol. 92, issue 6: 641-8

\section{Isabelle 2001 \{published data only\}}

Isabelle P, Bjamer D, Neuparth N, Desfougeres JL. Efficacy and safety of salmeterol/fluticasone combination 50/ 100 mug bd via two different powder devices in children. Annual Thoracic Society 97th International Conference; San Francisco CA ,May 18-23 2001.

Jarjour 2006 \{published data only\}

SAS40026. http://ctr.gsk.co.uk/Summary/ fluticasone_salmeterol/IV_SAS40026.pdf Acessed July 2008 .

* Jarjour NN, Wilson SJ, Koenig SM, Laviolette M, Moore WC, Davis WB, et al.Control of airway inflammation maintained at a lower steroid dose with 100/50 microg of fluticasone propionate/salmeterol. J Allergy Clin Immunol 2006;118:44-52.

\section{Johansson 2001 \{published data only\}}

Johansson G, McIvor RA, D’Ambrosio FP, Gratziou $\mathrm{C}$, James $\mathrm{MH}$. Comparison of salmeterol/fluticasone propionate combination with budesonide in patients with mild-to-moderate asthma. Clinical Drug Investigation 2001; Vol. 21, issue 9:633-42.

\section{Juniper 2002 \{published data only\}}

Juniper EF, Jenkins C, Price MJ, James MH. Impact of inhaled salmeterol/fluticasone propionate combination product versus budesonide on the health-related quality of life of patients with asthma. American Journal of Respiratory Medicine 2002; Vol. 1, issue 6:435-40.

Kelsen 1999 \{published data only\}

Kelsen SG, Church NL, Gillman SA, Lanier BQ, Emmett $\mathrm{AH}$, Rickard KA, et al.Salmeterol added to inhaled corticosteroid therapy is superior to doubling the dose of inhaled corticosteroids: A randomized clinical trial. Journal of Asthma 1999; Vol. 36, issue 8:703-15.

Koopmans 2005 \{published data only\}

Koopmans JG, Lutter R, Jansen HM, van der Zee JS. Adding salmeterol to an inhaled corticosteroid reduces allergen-induced serum IL-5 and peripheral blood eosinophils. Journal of Allergy \& Clinical Immunology 2005; Vol. 116, issue 5:1007-13.

\section{Lazarus 2001 \{published data only\}}

Lazarus SC, Boushey HA, Fahy JV, Chinchilli VM, Lemanske RF, Jr, et al.Long-Acting \{beta\}2-Agonist Monotherapy vs Continued Therapy With Inhaled Corticosteroids in Patients With Persistent Asthma: A Randomized Controlled Trial. JAMA 2001; Vol. 285, issue 20:2583-93.

\section{Lemanske 2001 \{published data only\}}

Lemanske RF, Jr, Sorkness CA, Mauger EA, Lazarus SC, Boushey HA, et al.Inhaled Corticosteroid Reduction and Elimination in Patients With Persistent Asthma Receiving Salmeterol: A Randomized Controlled Trial. JAMA 2001; Vol. 285, issue 20:2594-603.

Lotvall \{published data only\}

Lotvall J, Langley S, Woodcock A. Inhaled steroid/longacting beta 2 agonist combination products provide 24 hours improvement in lung function in adult asthmatic patients. Respiratory Research. Vol. 7, 2006. Article Number: 110. Date of Publication: 18 AUG 2006..

\section{Lundback 2000 \{published data only\}} Lundback B, Jenkins C, Price MJ, Thwaites RM. Cost-effectiveness of salmeterol/fluticasone propionate combination product 50/250 microg twice daily and budesonide 800 microg twice daily in the treatment of adults and adolescents with asthma. International Study Group. Respiratory Medicine 2000; Vol. 94, issue 7: 724-32. 
Martinat 2003 \{published data only\}

Martinat Y, Desfougeres JL. Fixed-dose fluticasonesalmeterol combination: At least effective and better tolerated than open-dose combinations. [French]. Revue de Pneumologie Clinique 2003; Vol. 59, issue 3:139-48.

Morice 2006 \{published data only\}

Morice A. An open labelled study to compare the systemic side effects of high dose fluticasone/salmeterol with that of high dose ciclesonide/salmeterol in symptomatic asthmatic patients. The North and South Bank Research and Development Consortium 2006; Vol. 1/7/2007:Ongoing.

\section{Murray 1999 \{published data only\}}

Murray JJ, Church NL, Anderson WH, Bernstein DI, Wenzel SE, Emmett A, et al.Concurrent use of salmeterol with inhaled corticosteroids is more effective than inhaled corticosteroid dose increases. Allergy \& Asthma Proceedings 1999; Vol. 20, issue 3:173-80.

Nan 2004 \{published data only\}

Nan SZ, Zheng JP, Humphries MJ, Xin D. Salmeterol/ fluticasone propionate in a single inhaler is superior to budesonide alone in control of Chinese asthmatic adults: An open-label, randomised, 6-week study. Clinical Drug Investigation 2004; Vol. 24, issue 10:583-92.

Nathan 2001 \{published data only\}

Nathan RA, Mitchell D, Condemi J, Heller A, Schoaf L, Herrle $\mathrm{M}$, et al.Cardiovascular and hypthalamic-pituitaryadrenal axis safety of fluticasone propionate/salmeterol hfa mdi in adolescent and adult patients with asthma. Annual Thoracic Society 97th International Conference; San Francisco CA ,May 18-23 2001

Nelson 2000 \{published data only\}

Nelson HS, Busse WW, Kerwin E, Church N, Emmett A, Rickard K, et al.Fluticasone propionate/salmeterol combination provides more effective asthma control than low-dose inhaled corticosteroid plus montelukast. Journal of Allergy \& Clinical Immunology 2000; Vol. 106, issue 6: 1088-95.

Nelson 2001 \{published data only\}

Nelson HS, Nathan RA, Kalberg C, Yancey SW, Rickard KA. Comparison of inhaled salmeterol and oral zafirlukast in asthmatic patients using concomitant inhaled corticosteroids. Medgenmed Computer File: Medscape General Medicine 2001; Vol. 3, issue 4:3.

O'Byrne 2005 \{published data only\}

O'Byrne P. Efficacy of ciclesonide vs fixed combination of fluticasone propionate/salmeterol vs placebo in patients with mild persistent asthma (12 to $75 \mathrm{y}$ ). clinicaltrials.gov 2005.

O'Connor 2004 \{published data only\}

O'Connor RD, Nelson H, Borker R, Emmett A, Jhingran P, Rickard K, et al.Cost effectiveness of fluticasone propionate plus salmeterol versus fluticasone propionate plus montelukast in the treatment of persistent asthma. Pharmacoeconomics 2004; Vol. 22, issue 12:815-25.
Pauwels 1998 \{published data only\}

Pauwels RA, Yernault JC, Demedt MG, Geusens P. Safety and efficacy of fluticasone and beclomethasone in moderate to severe asthma. Belgian Multicenter Study Group. American Journal of Respiratory \& Critical Care Medicine 1998; Vol. 157, issue 3 Pt 1:827-32.

\section{Pearlman 1999 \{published data only\}}

Pearlman DS, Stricker W, Weinstein S, Gross G, Chervinsky P, Woodring A, et al.Inhaled salmeterol and fluticasone: a study comparing monotherapy and combination therapy in asthma. Annals of Allergy, Asthma, \& Immunology 1999; Vol. 82, issue 3:257-65.

\section{Peters 2007 \{published data only\}}

Peters SP, Anthonisen N, Castro M, Holbrook JT, Irvin CG, Smith LJ, et al.Randomized comparison of strategies for reducing treatment in mild persistent asthma. New England Journal of Medicine 2007; Vol. 356, issue 20:2027-39.

Ringdal 2003 \{published data only\} Ringdal N, Eliraz A, Pruzinec R, Weber HH, Mulder PG, Akveld $\mathrm{M}$, et al.The salmeterol/fluticasone combination is more effective than fluticasone plus oral montelukast in asthma. Respiratory Medicine 2003; Vol. 97, issue 3: 234-41.

Rosenthal 1999 \{published data only\}

Rosenthal RR, Busse WW, Kemp JP, Baker JW, Kalberg C, Emmett A, et al.Effect of long-term salmeterol therapy compared with as-needed albuterol use on airway hyperresponsiveness. Chest 1999; Vol. 116, issue 3: 595-602.

Russell 1995 \{published data only\}

Russell G, Williams DA, Weller P, Price JF. Salmeterol xinafoate in children on high dose inhaled steroids. Annals of Allergy, Asthma, \& Immunology 1995; Vol. 75, issue 5: 423-8.

SAM30002 \{unpublished data only\}

SAM30002. http://ctr.gsk.co.uk/Summary/ fluticasone_salmeterol/III_SAM30002.pdf Accessed July 2008.

SAM30013 \{unpublished data only\}

SAM30013. http://ctr.glaxowellcome.co.uk/Summary/ fluticasone_salmeterol/III_SAM30013.pdf Accessed July 2008.

SAM40116 \{unpublished data only\}

SAM40116. http://ctr.glaxowellcome.co.uk/Summary/ fluticasone_salmeterol/III_SAM40116.pdf Accessed July 2008.

SAS30015 \{unpublished data only\} SAS30015. http://ctr.gsk.co.uk/Summary/ fluticasone_salmeterol/III_SAS30015.pdf Accessed July 2008.

Schermer 2007 \{published data only\}

Schermer TR, Albers JM, Verblackt HW, Costongs RJ, Westers P. Lower inhaled steroid requirement with a fluticasone/salmeterol combination in family practice patients with asthma or COPD. Family Practice 2007; Vol. 24 , issue $2: 181-8$. 
Schlosser 1998 \{published data only\}

Schlosser NJJ, Steinmetz KO, Aubier M, Gomez E, Wixon C. Evaluation of long term safety of salmeterol/fluticasone propionate $(50 / 500 \mu \mathrm{g})$ combination inhaler in patients with reversible airways obstruction. European Respiratory Journal. Supplement. 1998; Vol. 12 Suppl 28:35S.

Scott 2005 \{published data only\}

Scott C, Wu W, Ellsworth A, Crim C. Efficacy and safety of fluticasone propionate/salmeterol DISKUS and fluticasone propionate DISKUS and HFA in children [Abstract]. European Respiratory Journal 2005; Vol. 26, issue Suppl 49:Abstract No. 1057.

SLGA5021 \{published data only\}

SLGA5021. http://ctr.gsk.co.uk/Summary/

fluticasone_salmeterol/IV_SLGA5021.pdf Accessed August 11 th 2008

Tonnel 2004 \{published data only\}

Tonnel AB, Desfougeres JL. Efficacy and acceptability of the fixed fluticasone + salmeterol combination in the treatment of acute asthma attacks. Results of a one-year comparative study. [French]. Revue de Pneumologie Clinique 2004; Vol. 60, issue 4:209-16.

\section{Van den 2000 \{published data only\}}

Van den Berg NJ, Ossip MS, Hederos CA, Anttila H, Ribeiro BL, Davies PI. Salmeterol/fluticasone propionate $50 / 100$ microg in combination in a Diskus inhaler Seretide is effective and safe in children with asthma. Pediatric Pulmonology 2000; Vol. 30, issue 2:97-105.

\section{Van Noord 1999 \{published data only\}}

Van Noord JA, Schreurs AJM, Mol SJM, Mulder PGH. Addition of salmeterol versus doubling the dose of fluticasone propionate in patients with mild to moderate asthma. Thorax 1999; Vol. 54, issue 3:207-12.

\section{Vermetten 1999 \{published data only\}} Vermetten FA, Boermans AJM, Luiten WD, Mulder PGH, Vermue NA. Comparison of salmeterol with beclomethasone in adult patients with mild persistent asthma who are already on low-dose inhaled steroids. Journal of Asthma 1999; Vol. 36, issue 1:97-106.

\section{Woolcock 1996 \{published data only\}}

Woolcock A, Lundback B, Ringdal N, Jacques LA. Comparison of addition of salmeterol to inhaled steroids with doubling of the dose of inhaled steroids. American Journal of Respiratory \& Critical Care Medicine 1996; Vol. 153 , issue 5:1481-8.

You-Ning 2005 \{published data only\}

You-Ning L, Humphries M, Du X, Wang L, Jiang J. Efficacy and safety of salmeterol/fluticasone propionate delivered via a hydrofluoroalkane metered dose inhaler in Chinese patients with moderate asthma poorly controlled with inhaled corticosteroids. International Journal of Clinical Practice 2005; Vol. 59, issue 7:754-9.

Zhong 2002 \{published data only\}

Zhong N. Comparison of the effectiveness and safety in use of salmeterol/fluticasone delivered together in a Seretide Acuhaler or salmeterol and fluticasone delivered separately for patients with moderate or severe asthma. Chinese Journal of Tuberculosis and Respiratory Disease 2002; Vol. 25 , issue 6:371.

Zhong 2005 \{published data only\} Zhong NS, Zheng JP, Cai BQ, Xie CM, Sun TY, Wang $\mathrm{DQ}$, et al.[Evaluation of the clinical efficacy and the safety of salmeterol/fluticasone propionate accuhalar compared to budesonide turbuhalar in the control of adult asthma.]. Zhonghua Jie He He Hu Xi Za Zhi 2005; Vol. 28, issue 4: 233-7.

\section{Additional references}

\section{Altman 2003}

Altman DG, Bland JM. Statistics Notes: Interaction revisited: the difference between two estimates. BMJ 2003; 326(7382):219.

\section{Anderson 2006}

Anderson GP. Current issues with beta(2)-adrenoceptor agonists - Pharmacology and molecular and cellular mechanisms. Clinical Reviews in Allergy \& Immunology 2006; Vol. 31, issue 2-3:119-30.

\section{Arnold 1985}

Arnold JMO, Oconnor PC, Riddell JG, Harron DWG, Shanks RG, McDevitt DG. Effects of the beta-2adrenoceptor antagonist ici-118,551 on exercise tachycardia and isoprenaline-induced beta-adrenoceptor responses in man. British Journal of Clinical Pharmacology 1985; Vol. 19 , issue 5:619-30.

\section{Barnes 1993}

Barnes PJ. Beta-adrenoceptors on smooth-muscle, nerves and inflammatory cells. Life Sciences 1993; Vol. 52, issue 26:2101-9.

\section{Barnes 1995}

Barnes PJ. Beta-adrenergic receptors and their regulation. American Journal of Respiratory and Critical Care Medicine 1995; Vol. 152, issue 3:838-60.

\section{Bateman 2008}

Bateman E, Nelson H, Bousquet J, Kral K, Sutton L, Ortega $\mathrm{H}$, et al.Meta-analysis: Effects of Adding Salmeterol to Inhaled Corticosteroids on Serious Asthma-Related Events. Ann Intern Med 2008; Vol. 149, issue 1:33-42.

\section{Beach 1992}

Beach JR, Young CL, Stenton SC, Avery AJ, Walters EH, Hendrick DJ. A comparison of the speeds of action of salmeterol and salbutamol in reversing methacholineinduced bronchoconstriction. Pulm-Pharmacol 1992;5(2): $133-5$.

Bennett 1994

Bennett JA, Smyth ET, Pavord ID, Wilding PJ, Tattersfield AE. Systemic effects of salbutamol and salmeterol in patients with asthma. Thorax 1994; Vol. 49, issue 8:771-4.

\section{Brown 1983}

Brown MJ, Brown DC, Murphy MB. Hypokalemia from beta-2-receptor stimulation by circulating epinephrine. New England Journal of Medicine 1983; Vol. 309, issue 23:1414-9. 
Burgess 1991

Burgess CD, Windom HH, Pearce N, Marshall S, Beasley R, Siebers RWL, et al.Lack of evidence for beta-2 receptor selectivity - a study of metaproterenol, fenoterol, isoproterenol, and epinephrine in patients with asthma. American Review of Respiratory Disease 1991; Vol. 143, issue 2:444-6.

Burggraaf 2001

Burggraaf J, Westendorp RGJ, in't Veen J, Schoemaker RC Sterk PJ, Cohen AF, et al.Cardiovascular side effects of inhaled salbutamol in hypoxic asthmatic patients. Thorax 2001; Vol. 56, issue 7:567-9.

\section{Cates 2008}

Cates Christopher J, Cates Matthew J, Lasserson Toby J. Regular treatment with formoterol for chronic asthma: serious adverse events. Cochrane Database of Systematic Reviews 2008, Issue 4. [DOI: 10.1002/ 14651858.CD006923.pub2; : CD006923]

\section{Cates 2008a}

Cates CJ, Cates MJ. Regular treatment with salmeterol for chronic asthma: serious adverse events. Cochrane Database of Systematic Reviews 2008, Issue 3. [DOI: 10.1002/ 14651858.CD006363.pub2; : CD006363]

\section{Cates 2009}

Cates CJ, Lasserson TJ, Jaeschke R. Regular treatment with formoterol and inhaled steroids for chronic asthma: serious adverse events. Cochrane Database of Systematic Reviews 2009, Issue 2. [DOI: 10.1002/14651858. CD006924.pub2; : CD006924]

\section{Cockcroft 1993}

Cockcroft DW, McParland CP, Britto SA, Swystun VA, Rutherford BC. Regular inhaled salbutamol and airway responsiveness to allergen. Lancet 1993; Vol. 342, issue 8875:833-7.

\section{Collins 1969}

Collins JM, McDevitt DG, Shanks RG, Swanton JG. Cardio-toxicity of isoprenaline during hypoxia. British Journal of Pharmacology 1969; Vol. 36, issue 1:35-\&.

\section{Crane 1989}

Crane J, Pearce N, Flatt A, Burgess C, Jackson R, Kwong $\mathrm{T}$, et al.Prescribed fenoterol and death from asthma in New Zealand, 1981-83 - case-control study. Lancet 1989; Vol. 1 , issue 8644:917-22.

\section{Ducharme 2006}

Ducharme FM, Lasserson TJ, Cates CJ. Long-acting beta2 agonists versus anti-leukotrienes as add-on therapy to inhaled corticosteroids for chronic asthma (Cochrane Review). Cochrane Database of Systematic Reviews 2006, Issue 4. [DOI: 10.1002/14651858.CD003137.pub3; : CD003137]

\section{FDA 2008}

GlaxoSmithKline. Benefit Risk Assessment of Salmeterol for the Treatment of Asthma in Adults and Children. www.fda.gov/ohrms/dockets/ac/08/briefing/2008-4398b104-GSK.pdf Accessed February 24th 2009.

\section{Giembycz 2006}

Giembycz MA, Newton R. Beyond the dogma: novel B2adrenoceptor signalling in the airways. European Respiratory Journal 2006;27(6):1286-1306.

\section{Grainger 1991}

Grainger J, Woodman K, Pearce N, Crane J, Burgess C, Keane A, et al.Prescribed fenoterol and death from asthma in New Zealand, 1981-7 - a further case-control study. Thorax 1991; Vol. 46, issue 2:105-11.

\section{Greenstone 2005}

Greenstone IR, Ni Chroinin M, Masse V, Danish A, Magdalinos H, Zhang X, et al.Combination of inhaled long-acting beta2-agonists and inhaled steroids versus higher dose of inhaled steroids in children and adults with persistent asthma (Cochrane Review). Cochrane Database of Systematic Reviews 2005, Issue 4. [DOI: 10.1002/ 14651858.CD005533; : CD005533]

\section{Guhan 2000}

Guhan AR, Cooper S, Oborne J, Lewis S, Bennett J, Tattersfield AE. Systemic effects of formoterol and salmeterol: a dose-response comparison in healthy subjects. Thorax 2000; Vol. 55, issue 8:650-6.

\section{Hall 1989}

Hall JA, Petch MC, Brown MJ. Intracoronary injections of salbutamol demonstrate the presence of functional beta-2adrenoceptors in the human-heart. Circulation Research 1989; Vol. 65, issue 3:546-53.

\section{Hanania 2002}

Hanania NA, Sharfkhaneh A, Barber R, Dickey BF. betaagonist intrinsic efficacy - Measurement and clinical significance. American Journal of Respiratory and Critical Care Medicine 2002; Vol. 165, issue 10:1353-8.

\section{Hanania 2007}

Hanania NA, Moore RH, Zimmerman JL, Miller CT, Bag $\mathrm{R}$, Sharafkhaneh A, et al.The role of intrinsic efficacy in determining response to beta(2)-agonist in acute severe asthma. Respiratory Medicine 2007; Vol. 101, issue 5: 1007-14.

\section{Hancox 1999}

Hancox RJ, Aldridge RE, Cowan JO, Flannery EM, Herbison GP, McLachlan CR, et al.Tolerance to betaagonists during acute bronchoconstriction. European Respiratory Journal 1999; Vol. 14, issue 2:283-7.

\section{Hancox 2006}

Hancox RJ. Interactions between corticosteroids and beta2agonists. Clinical Reviews in Allergy \& Immunology 2006; Vol. 31, issue 2-3:231-46. [: (Print)]

\section{Haney 2006}

Haney S, Hancox RJ. Recovery from bronchoconstriction and bronchodilator tolerance. Clinical Reviews in Allergy \& Immunology 2006; Vol. 31, issue 2-3:181-96.

\section{Harvey 1982}

Harvey JE, Tattersfield AE. Airway response to salbutamol effect of regular salbutamol inhalations in normal, atopic, and asthmatic subjects. Thorax 1982; Vol. 37, issue 4: 280-7. 


\section{ICHE2a 1995}

Expert Working Group (Efficacy) of theInternational Conference on Harmonisation of Technical Requirements for Registrationof Pharmaceuticals for Human Use (ICH). Clinical safety data management: Definitions and standards for expedited reporting. http://www.fda.gov/cder/guidance/ iche2a.pdf 1995.

\section{Jaeschke 2008}

Jaeschke R, O'Byrne PM, Parameswaran N, et al.The safety of formoterol among patients with asthma using inhaled corticosteroids. Systematic review and meta-analysis.. Pol Arch Med Wewn 2008; Vol. 118, issue 11:627-635.

\section{Jaeschke 2008a}

Jaeschke R, O'Byrne PM, Mejza F, Nair P, Lesniak W, Brozek J, et al.The Safety of Long-Acting Beta-Agonists among Patients with Asthma Using Inhaled Corticosteroids: Systematic Review and Meta-analysis. Am. J. Respir. Crit. Care Med. 2008; Vol. 178, issue 10:1009-16.

\section{Jones 2001}

Jones SL, Cowan JO, Flannery EM, Hancox RJ, Herbison GP, Taylor DR. Reversing acute bronchoconstriction in asthma: the effect of bronchodilator tolerance after treatment with formoterol. European Respiratory Journal 2001; Vol. 17, issue 3:368-73.

\section{Lee 2003}

Lee DKC, Jackson CM, Currie GP, Cockburn WJ, Lipworth BJ. Comparison of combination inhalers vs inhaled corticosteroids alone in moderate persistent asthma. British Journal of Clinical Pharmacology 2003; Vol. 56, issue 5:494-500.

\section{Lipworth 1989}

Lipworth BJ, Struthers AD, McDevitt DG. Tachyphylaxis to systemic but not to airway responses during prolonged therapy with high-dose inhaled salbutamol in asthmatics. American Review of Respiratory Disease 1989; Vol. 140, issue 3:586-92.

\section{Lipworth 1992}

Lipworth BJ, McDevitt DG. Inhaled beta-2-adrenoceptor agonists in asthma - help or hindrance. British Journal of Clinical Pharmacology 1992; Vol. 33, issue 2:129-38.

\section{Lipworth 1997}

Lipworth BJ. Airway subsensitivity with long-acting beta 2 agonists: Is there cause for concern?. Drug Safety 1997;16 (5):295-308.

\section{Lipworth 2000}

Lipworth BJ, Aziz I. Bronchodilator response to albuterol after regular formoterol and effects of acute corticosteroid administration. Chest 2000; Vol. 117, issue 1:156-62.

\section{McDevitt 1974}

McDevitt DG, Shanks RG, Swanton JG. Further observations on cardiotoxicity of isoprenaline during hypoxia. British Journal of Pharmacology 1974; Vol. 50, issue 3:335-44.

\section{Morrison 1993}

Morrison KJ, Gao Y, Vanhoutte PM. Beta-adrenoceptors and the epithelial layer in airways. Life Sciences 1993; Vol. 52, issue 26:2123-30.

\section{Nelson 1977}

Nelson HS, Raine D, Doner HC, Posey WC. Subsensitivity to bronchodilator action of albuterol produced by chronic administration. American Review of Respiratory Disease 1977; Vol. 116, issue 5:871-8.

\section{Ni Chroinin 2004}

Ni Chroinin M, Greenstone IR, Ducharme FM. Addition of inhaled long-acting beta2-agonists to inhaled steroids as first line therapy for persistent asthma in steroid-naive adults (Cochrane Review). Cochrane Database of Systematic Reviews 2004, Issue 4. [DOI: 10.1002/14651858.CD005307; : CD005307]

\section{Ni Chroinin 2005}

Ni Chroinin M, Greenstone IR, Danish A, Magdolinos H, Masse V, Zhang X, et al.Long-acting beta2-agonists versus placebo in addition to inhaled corticosteroids in children and adults with chronic asthma (Cochrane Review). Cochrane Database of Systematic Reviews 2005, Issue 4. [DOI: 10.1002/14651858.CD005535; : CD005535]

\section{Palmqvist 1999}

Palmqvist M, Ibsen T, Mellen A, Lotvall J. Comparison of the relative efficacy of formoterol and salmeterol in asthmatic patients. American Journal of Respiratory and Critical Care Medicine 1999; Vol. 160, issue 1:244-9.

\section{Pearce 1990}

Pearce N, Grainger J, Atkinson M, Crane J, Burgess C, Culling C, et al.Case-control study of prescribed fenoterol and death from asthma in new-zealand, 1977-81. Thorax 1990; Vol. 45, issue 3:170-5.

\section{Pearce 2007}

Pearce N. Adverse reactions: the Fenoterol story. 1. Auckland: Auckland University Press, 2007:215. [: 9781869403744]

\section{Salpeter 2006}

Salpeter SR, Buckley NS, Ormiston T M, Salpeter EE. Meta-analysis: effect of long-acting beta-agonists on severe asthma exacerbations and asthma-related deaths. Annals of Internal Medicine 2006;144(12):904-12.

\section{Sears 1986}

Sears M, Rea H, Rothwell R, O’Donnell T, Holst P, Gillies A, et al.Asthma mortality: comparison between New Zealand and England. British Medical Journal 1986;293 (6558):1342-5.

\section{Sears 1990}

Sears MR, Taylor DR, Print CG, Lake DC, Li QQ, Flannery EM, et al.Regular inhaled beta-agonist treatment in bronchial-asthma. Lancet 1990; Vol. 336, issue 8728: 1391-6.

\section{Sears 2008}

Sears MR, Ottosson A, Radner F, Suissa S. Long-acting $\{$ beta\}-agonists: A review of formoterol safety data from 
asthma clinical trials. European Respiratory Journal 2008: 09031936.00145006 .

\section{SMART 2006}

Nelson HS, Weiss ST, Bleecker ER, Yancey SW, Dorinsky PM, the SMART Study Group. The Salmeterol Multicenter Asthma Research Trial: A Comparison of Usual Pharmacotherapy for Asthma or Usual Pharmacotherapy Plus Salmeterol. Chest 2006;129:15-26.

\section{SNS 1993}

Castle W, Fuller R, Hall J. Serevent nationwide surveillance study:Comparison of salmeterol with salbutamol in asthmatic patients who require regular bronchodilator treatment. British Medical Journal 1993;306:1034-7.

\section{Speizer 1968}

Speizer FE, Doll R, Heaf P. Observations on recent increase in mortality from asthma. British Medical Journal 1968; Vol. 1, issue 5588:335-\&.

\section{Sweeting 2004}

Sweeting MJ, Sutton AJ, Lambert PC. What to add to nothing? Use and avoidance of continuity corrections in meta-analysis of sparse data. Stat Med. 2004/04/30 2004; Vol. 23, issue 9:1351-75. [0277-6715: (Print)]

\section{van der Woude 2001}

van der Woude HJ, Winter TH, Aalbers R.

Decreased bronchodilating effect of salbutamol in relieving methacholine induced moderate to severe bronchoconstriction during high dose treatment with long acting beta(2) agonists. Thorax 2001; Vol. 56, issue 7: $529-35$.

\section{vanNoord 1996}

vanNoord JA, Smeets JJ, Raaijmakers JAM, Bommer AM, Maesen FPV. Salmeterol versus formoterol in patients with moderately severe asthma: Onset and duration of action. European Respiratory Journal 1996; Vol. 9, issue 8:1684-8.

\section{Walters 2002}

Walters EH, Walters JAE, Gibson PW. Regular treatment with long acting beta agonists versus daily regular treatment with short acting beta agonists in adults and children with stable asthma (Cochrane Review). Cochrane Database of Systematic Reviews 2002, Issue 3. [DOI: 10.1002/ 14651858.CD003901]

\section{Walters 2007}

Walters EH, Gibson PG, Lasserson TJ, Walters JAE. Longacting beta2-agonists for stable chronic asthma (Cochrane Review). Cochrane Database of Systematic Reviews 2007, Issue 1. [DOI: DOI: 10.1002/14651858.CD001385.pub2]

\section{Weber 1982}

Weber RW, Smith JA, Nelson HS. Aerosolized terbutaline in asthmatics - development of subsensitivity with longterm administration. Journal of Allergy and Clinical Immunology 1982; Vol. 70, issue 6:417-22.

\section{Weiss 2008}

Weiss KB. Drug safety and salmeterol: the controversy continues. Ann Intern Med. 2008/06/05 2008; Vol. 149, issue 1:56-7. [1539-3704: (Electronic)]

\section{Wilson 1981}

Wilson JD, Sutherland DC, Thomas AC. Has the change to beta-agonists combined with oral theophylline increased cases of fatal asthma. Lancet 1981; Vol. 1, issue 8232: $1235-7$.

\section{Wong 1990}

Wong CS, Pavord ID, Williams J, Britton JR, Tattersfield AE. Bronchodilator, cardiovascular, and hypokalaemic effects of fenoterol, salbutamol, and terbutaline in asthma. Lancet 1990; Vol. 336, issue 8728:1396-9.

\section{Yates 1996}

Yates DH, Kharitonov SA, Barnes PJ. An inhaled glucocorticoid does not prevent tolerance to the bronchoprotective effect of a long-acting inhaled beta(2)agonist. American Journal of Respiratory and Critical Care Medicine 1996; Vol. 154, issue 6:1603-7.

* Indicates the major publication for the study 


\section{CHARACTERISTICS OF STUDIES}

\section{Characteristics of included studies [ordered by study ID]}

\section{Aubier 1999}

Methods

A randomized, double-blind, double-dummy, multi centre, parallel-group study over 28 weeks from May 1996 to November 1997 at 55 centres in 3 countries. (Germany, Franceand the Netherlands) Run-in 2 weeks and follow-up 2 weeks

Population: 503 adolescents and adults $(12-79)$ years with asthma.
Baseline Characteristics: Mean age 48 years. FEV $73 \%$ predicted.
Concomitant inhaled corticosteroids used by $100 \%$ of participants
Inclusion Criteria:At least 12 years old with a documented clinical history of reversible
airways disease, and received treatment with any inhaled corticosteroid continuously for
12 weeks prior to run-in. FEV $\%$ predicted between $50 \%$ to $100 \%$, At the end of the 2 -
week run-in period were symptomatic (symptom score 2 or more on at least four of the
last seven consecutive days), had a mean morning peak expiratory flow rate (PEFR) that
was $>50 \%$ and $<85 \%$ of the maximum PEFR 15 min after administration of inhaled
salbutamol 400 ug
Exclusion Criteria: taking long-acting beta2-agonists

\begin{tabular}{l|l}
\hline Interventions & 1. FSC $500 / 50 \mu \mathrm{g} \mathrm{BD}$ \\
2. FP $500 \mu \mathrm{g}+\mathrm{SAL} 50 \mu \mathrm{g} \mathrm{BD}$ \\
3. FP $500 \mu \mathrm{g}$ BD \\
Delivery was Diskus device
\end{tabular}

Outcomes

Primary outcome: Mean morning peak expiratory flow rate (PEFR) during Weeks 1-12 The paper reports "The incidence of drug-related adverse events was similar for the three treatments"

Full SAE data from web report. One death from bronchial carcinoma on salmeterol and fluticasone (separate inhalers). This death was not included in Jaeschke 2008 as the patient stopped taking study medication to allow for elective surgery and died of surgical complications, but was still in the trial and had intended to restart treatment post-operatively

Notes

Risk of bias

\begin{tabular}{lll}
\hline Item & Authors' judgement & Description \\
\hline Adequate sequence generation? & Unclear & Not reported \\
\hline Allocation concealment? & Unclear & Not reported \\
\hline $\begin{array}{l}\text { Blinding? } \\
\text { All outcomes }\end{array}$ & Yes & Double blind double dummy \\
\hline $\begin{array}{l}\text { Incomplete outcome data addressed? } \\
\text { All outcomes }\end{array}$ & Yes & $403 / 503(80 \%)$ completed the study \\
\hline
\end{tabular}


Aubier 1999 (Continued)

\begin{tabular}{|c|c|c|}
\hline Free of selective reporting? & Yes & Full data on GSK website \\
\hline
\end{tabular}

\section{Bateman 2001}

Methods

A randomized, double-blind, double-dummy, multicenter, parallel-group study over 12 weeks from March 1998 to June 1999 at 69 centers in 10 countries. Run in 2 weeks and 2 weeks follow-up

Participants

Population: 497 adolescents and adults (12-79) years with documented clinical history of reversible airways obstruction

Baseline Characteristics: Mean age 40 years. FEV $_{1} 76 \%$ predicted. Concomitant inhaled corticosteroids used by $100 \%$ of participants

Inclusion Criteria: 12 years or older with a documented clinical history of reversible airway obstruction, a smoking history of less than 10 pack-years and been using ICS (beclomethasone dipropionate, budesonide or flunisolide $400-500 \mu \mathrm{g}$ day or FP 200$250 \mu \mathrm{g}$ day) for at least 4 weeks before entering the run-in period. $\mathrm{FEV}_{1} \%$ predicted at least $50 \%$.

Mean PEF over the last 7 days of the run-in period of between $50 \%$ and $85 \%$ measured after inhalation of salbutamol $(400 \mathrm{mg})$. Had to be symptomatic, i.e. have a cumulative total symptom score (daytime plus night-time) greater than 8 for the last 7 days of the run-in period, and be taking salbutamol up to $800 \mu \mathrm{g}$ day.

Exclusion Criteria: Received a long-acting $\mathrm{B}_{2}$-agonist or oral $\mathrm{B}_{2}$-agonist within 2 weeks of the run-in period, changed asthma medication, had a lower respiratory tract infection within 4 weeks of the run-in period or had an acute asthma exacerbation requiring hospitalization within 12 weeks of study entry. Other exclusion criteria included prior treatment with oral, depot or parenteral corticosteroids or combination therapy (containing a $\mathrm{B}_{2}$-agonist and/or ICS).

Interventions

1. SALM/FP 50/100 $\mu \mathrm{g}$ HFA MDI

2. SALM/FP $50 / 100 \mu \mathrm{g}$ Diskus

3. FP $100 \mu \mathrm{g}$ CFC MDI

Outcomes

Primary efficacy variable was the mean morning PEFR over the 12-week treatment period A serious adverse event was described as any event which was fatal, life-threatening, disabling or incapacitating, or which required or prolonged hospitalisation

Paper reports: "During treatment, serious adverse events were reported by three patients $(2 \%)$ in each group. These included asthma exacerbations (n.5), breast neoplasia (n.1) and events associated with the gastrointestinal system (n.2) and ear, nose and throat (n. 1). The only serious adverse events considered by the investigator to be drug-related were asthma exacerbations in two patients (one each in the SALM/FP MDI and DiskusTM groups).”

SFCB3022 reports 5 patients with asthma SAE in SALM/FP groups (333 pts) and none on FP alone (165 pts)

Risk of bias 
Bateman 2001 (Continued)

\begin{tabular}{lll}
\hline Item & Authors' judgement & Description \\
\hline Adequate sequence generation? & Unclear & Not reported \\
\hline $\begin{array}{l}\text { Allocation concealment? } \\
\text { Blinding? }\end{array}$ & Unclear & Not reported \\
\hline $\begin{array}{l}\text { All outcomes } \\
\text { Ancomplete outcome data addressed? }\end{array}$ & Yes & Double blind, double dummy \\
\hline Free of selective reporting? & Yes & $430 / 497$ (87\%) completed the study \\
\hline
\end{tabular}

GOAL 2004

Methods

(at)

A randomized, double-blind, multicentre, stratified, parallel-group study over 12 months from December 2000 to December 2002 in 326 centres in Europe, North America, Latin America and Asia Pacific. Run-in 4 weeks

\begin{tabular}{|c|c|}
\hline Participants & $\begin{array}{l}\text { Population: } 3416 \text { adolescents and adults }(9-83) \text { with ur } \\
\text { Baseline Characteristics: Mean age } 40 \text { years. } \mathrm{FEV}_{1} 77 \\
\text { haled corticosteroids not previously used in stratum } 1 \text {, lov } \\
\text { to high dose in stratum } 3 \text { at baseline. } \\
\text { Inclusion Criteria: } 12 \text { years old or more and less than } \\
\text { month history of asthma, bronchodilator reversibility by } \\
\mathrm{FEV}_{1} \text { over baseline (and } 200 \mathrm{~mL} \text { ) based on } \mathrm{FEV}_{1} \text { measu } \\
\text { any short-acting beta2-agonist within the last six month } \\
\text { at Visit } 1 \text {, Visit } 2 \text {, or between Visit } 1 \text { and Visit } 2 \text { usir } \\
\text { albuterol. } \\
\text { Eligible for Stratum } 1 \text { of the study if had not received ir } \\
\text { at least } 6 \text { months prior to Visit } 1 \text {. For Stratum } 2 \text {, if rec } \\
\text { equivalent daily, Stratum } 3 \text {, receiving }>500 \text { and }<0 \text { r } \\
\text { daily } \\
\text { During two or more of the } 4 \text { weeks prior to Visit } 2 \text {, subje } \\
\text { the criteria for 'Well-Controlled' asthma. } \\
\text { Exclusion Criteria: assessed as having Well-Controllec } \\
4 \text { weeks during run-in, change in regular asthma medi } \\
\text { asthma; treatment with systemic corticosteroids; respira } \\
3 \text { days of morning PEF less than } 50 \% \text { predicted; non-cc } \\
\text { card }\end{array}$ \\
\hline Interventions & $\begin{array}{l}\text { 1. FSC } 100 / 50,250 / 50 \text { or } 500 / 50 \mu \mathrm{g} \text { BD (by strata) } \\
\text { 2. FP } 100,250 \text { or } 500 \mu \mathrm{g} \text { BD (by strata) } \\
\text { Delivery was Diskus device }\end{array}$ \\
\hline
\end{tabular}




\begin{tabular}{|c|c|c|}
\hline Outcomes & \multicolumn{2}{|c|}{$\begin{array}{l}\text { The primary efficacy variable was the proportion of subjects who achieved 'Well-Con- } \\
\text { trolled' asthma with the salmeterol/FP combination compared with FP alone during } \\
\text { Phase I of the study } \\
\text { Paper states that "Serious adverse events were observed during the double-blind period in } \\
4 \% \text { and } 3 \% \text { of patients in the salmeterol/fluticasone and fluticasone arms, respectively" } \\
\text { Web report gives the number of patients ( } 67 \text { and } 53 \text { respectively) } \\
\text { Website reports two deaths on FP (both Myocardial Infarction) and three deaths on FPS } \\
\text { (two Myocardial infarction and one pneumonia). No asthma-related deaths are reported }\end{array}$} \\
\hline \multicolumn{3}{|l|}{ Notes } \\
\hline \multicolumn{3}{|l|}{ Risk of bias } \\
\hline Item & Authors' judgement & Description \\
\hline Adequate sequence generation? & Yes & $\begin{array}{l}\text { Randomization was done telephonically } \\
\text { from a computer-generated allocation } \\
\text { schedule balanced per stratum and per } \\
\text { country }\end{array}$ \\
\hline Allocation concealment? & Unclear & Not reported \\
\hline $\begin{array}{l}\text { Blinding? } \\
\text { All outcomes }\end{array}$ & Yes & Double-blind \\
\hline $\begin{array}{l}\text { Incomplete outcome data addressed? } \\
\text { All outcomes }\end{array}$ & Yes & $2890 / 3416(85 \%)$ completed the study \\
\hline Free of selective reporting? & Yes & Full data on GSK website \\
\hline
\end{tabular}

Ind 2003

Methods

A randomized, double-blind, double-dummy, multicenter, parallel-group study over 28 weeks from January 1995 to December 1996 at 99 centers in Canada, Denmark, Iceland, Ireland, Italy and the United Kingdom. Run- in 4 weeks

Participants

Population: 502 adolescents and adults (16-75) years with asthma poorly controlled on current inhaled corticosteroids.

Baseline Characteristics: Mean age 45 years. $\mathrm{FEV}_{1}$ 2.3L. Concomitant inhaled corticosteroids used by $100 \%$ of participants.

Inclusion Criteria: Currently receiving inhaled corticosteroids at a dose of 1000 to 1600 mcg daily of inhaled beclomethasone dipropionate (BDP) or equivalent. Asthma poorly controlled (demonstrated by a PEFR of $? 85 \%$ of maximal achievable PEFR after inhaling $400 \mathrm{mcg}$ salbutamol) and had experienced at least 2 exacerbations of asthma in the last year that required a change in asthma therapy. Therefore, over the last 10 days of the baseline period had to demonstrate an average morning PEFR which was $<90 \%$ of their maximal achievable PEFR measured at screening and a diurnal variation in PEFR of at least $15 \%$. They also had to have asthma symptoms on at least 4 of the last 7 days or 
nights of the baseline period

Exclusion Criteria: receiving continuous oral corticosteroids, any serious uncontrolled systemic disease or participation was deemed unsuitable

by the physician, had to demonstrate a period variation in PEF of at least $15 \%$ (highest evening value-lowest morning value as a percentage of highest

PEF) over the last 10 days and/or nights of the run-in period and to have sub-optimal PEF, with average PEF over the last 10 days of the run-in not exceeding $90 \%$ of postbronchodilator PEF (measured at visit 1)

\begin{tabular}{l|l}
\hline Interventions & 1. FP $250 \mu \mathrm{g}+\mathrm{SAL} 50 \mu \mathrm{g} \mathrm{BD}$ \\
2. FP $250 \mu \mathrm{g}$ BD \\
3. FP $500 \mu \mathrm{g}$ BD \\
Delivery was MDI (FP 500 arm not used in this review)
\end{tabular}

Outcomes

The primary efficacy variables were: mean morning peak expiratory flow rate (PEFR); incidence and severity of asthma exacerbations

No SAE information found in paper publication. Full SAE data on web report. One fatal pneumothorax on Salmeterol and Fluticasone (separate inhalers)

Notes

Risk of bias

\begin{tabular}{lll}
\hline Item & Authors judgement & Description \\
\hline Adequate sequence generation? & Unclear & Not reported \\
\hline $\begin{array}{l}\text { Allocation concealment? } \\
\text { Blinding? }\end{array}$ & Unclear & Not reported \\
\hline $\begin{array}{l}\text { All outcomes } \\
\text { All outcomes }\end{array}$ & Yes & Double blind, double dummy \\
\hline \begin{tabular}{l} 
Free of selective reporting? \\
\hline
\end{tabular} & Yes & $432 / 502$ (86\% completed study) \\
\hline
\end{tabular}

\section{Kavuru 2000}

Methods

Participants
Randomized, double-blind, double-dummy, parallel-group placebo-controlled study over 12 weeks at 42 centers in the U.S. Run in 2 weeks single blind placebo

Population: 356adolescents and adults (12-70) years with asthma.

Baseline Characteristics: Mean age 37 years. $\mathrm{FEV}_{1} 64 \%$ predicted.

Concomitant inhaled corticosteroids used by $100 \%$ of participants in group 1 and $0 \%$ of participants in group 2.

Inclusion Criteria: At least 12 years old and a medical history of asthma, (as defined by the American Thoracic Society) of at least 6 months duration. FEV $1 \%$ predicted 
Kavuru 2000 (Continued)

between $40 \%$ to $85 \%$, bronchodilator reversibility by an increase of at least $15 \%$ in FEV
over baseline 30 minutes after two puffs $(180 \mu$ g) of inhaled albuterol
Stratified into 2 groups according to type of asthma therapy used at enrollment.
Exclusion Criteria: History of life-threatening asthma; hypersensitivity reaction to sym-
pathomimetic drugs or corticosteroids; smoking within the previous year or a history
of $>10$ pack-years; use of oral, inhaled or injectable corticosteroid therapy within the
previous month; use of intranal corticosteroid therapy except for Flonase (GlaxoW-
ellcome Inc.); use of daily oral corticosteroid treatment within the previous 6 months;
use of any other prescription or over-the-counter medication that could have affected
the course of asthma or interacted with sympathomimetic amines; abnormal chest x-ray
films; clinically significant abnormal 12-lead electrocardiograms (ECGs); or a history of
significant concurrent disease (e.g., glaucoma, diabetes, hypertension)

\begin{tabular}{l|l}
\hline Interventions & 1. FSC $100 / 50 \mu \mathrm{g}$ BD \\
2. Fluticasone $100 \mu \mathrm{g} \mathrm{BD}$ \\
Delivery was Diskus inhaler
\end{tabular}

Outcomes

Mean morning pre-dose Forced Expiratory Volume in 1 second $\left(\mathrm{FEV}_{1}\right)$ at endpoint; area under the 12-hour serial $\mathrm{FEV}_{1}$ curve relative to baseline [AUC(bl)] after I week of treatment (mean $\mathrm{FEV}_{1}$ AUC); and probability of remaining in the study over time without withdrawal due to lack of efficacy

Paper reports no serious drug-related adverse events, and reports two serious adverse events that led to withdrawal. Website records 2 events on FSC and 1 event on FP. (Unclear whether the 2 FSC events were in separate patients, so treated as one patient until further clarification)

Notes

Risk of bias

\begin{tabular}{lll}
\hline Item & Authors' judgement & Description \\
\hline Adequate sequence generation? & Unclear & Not reported \\
\hline $\begin{array}{l}\text { Allocation concealment? } \\
\text { Blinding? } \\
\text { All outcomes }\end{array}$ & Unclear & Not reported \\
\hline $\begin{array}{l}\text { Incomplete outcome data addressed? } \\
\text { All outcomes }\end{array}$ & Yes & Double blind, double dummy \\
\hline \begin{tabular}{l} 
Free of selective reporting? \\
\hline
\end{tabular} & Yes & $142 / 182(78 \%)$ completed the study \\
\hline
\end{tabular}




\begin{tabular}{|c|c|}
\hline Methods & $\begin{array}{l}\text { A randomized, double-blind, multicenter, parallel-group study over } 40 \text { weeks from } \\
\text { February } 2003 \text { to October } 2004 \text { at } 55 \text { sites. ( } 50 \text { in the US, } 3 \text { in Latin America, } 2 \text { in } \\
\text { Latvia). Run-in } 2 \text { weeks }\end{array}$ \\
\hline Participants & $\begin{array}{l}\text { Population: } 466 \text { adolescents and adults }(12-81) \text { with asthma. } \\
\text { Baseline Characteristics: Mean age } 34 \text { years. } \mathrm{FEV}_{1} 78 \% \text { predicted. Concomitant in- } \\
\text { haled corticosteroids used by } 100 \% \text { of participants. } \\
\text { Inclusion Criteria: } 12 \text { years of age or older, with a diagnosis of asthma, as defined by } \\
\text { the American Thoracic Society (ATS), for at least three months prior to visit } 1 \text {, must } \\
\text { have been treated with a short-acting beta2-agonist, an anticholinergic, or an allowed } \\
\text { ICS at a fixed dosing regimen (within an allowed total daily dose) for at least four weeks } \\
\text { prior to the screening visit. FEV } 1 \% \text { predicted between } 60 \% \text { to } 95 \% \text {, bronchodilator } \\
\text { reversibility by an increase of at least } 12 \% \text { in FEV } \mathrm{F}_{1} \text { over baseline within } 30 \text { minutes of } \\
\text { inhalation } 2 \text { puffs of inhaled albuterol.( } 180 \mu \mathrm{\mu g} \text { ) } \\
\text { Exclusion Criteria: pregnancy, life-threatening asthma, hospitalization attributable to } \\
\text { asthma within the last } 6 \text { months, current smoker or a more than } 10 \text { pack-year history of } \\
\text { smoking, a recent (within } 2 \text { weeks) upper or lower respiratory tract infection, or signif- } \\
\text { cant concurrent diseases. Medications that could confound the evaluation of the study } \\
\text { treatments or treatment strategies were prohibited before and throughout the study, in- } \\
\text { cluding inhaled (up to } 250 \text { mcg FP allowed prior to randomization), oral, or parenteral } \\
\text { corticosteroids (with the exception of protocol defined use of oral corticosteroids fol- } \\
\text { lowing second consecutive assignment to the highest dose of FP), theophylline or other } \\
\text { bronchodilators, leukotriene modifiers, anticholinergics, cromolyn, and nedocromil }\end{array}$ \\
\hline
\end{tabular}

Interventions
$\begin{aligned} & \text { 1. FSC } 100 / 50,250 / 50 \text { or } 500 / 50 \mu \mathrm{g} \text { BD (BHR strategy) } \\ & \text { 2. FP } 100,250 \text { or } 500 \mu \mathrm{g} \text { (BHR strategy) } \\ & \text { 3. FP } 100,250 \text { or } 500 \mu \mathrm{g} \text { (Reference strategy) - data was not used from this arm } \\ & \text { Delivery was Diskus device }\end{aligned}$

Putcomes
trimary efficacy variable was the average inhaled corticosteroid treatment dose over the
Paper reports "There were no non-fatal serious adverse events in any treatment group
that were considered to be drug related. One patient in the $\mathrm{FP}_{B H R}$ treatment group died
due to convulsions and cardiac arrest following deep vein thrombosis."
Web report indicates one patient with SAE related to asthma on FSC $\mathrm{C}_{B H R}$ and one patient
with ear infection and sinusitis on $\mathrm{FP}_{B H R}$.

Notes

\section{Risk of bias}

\begin{tabular}{lll}
\hline Item & Authors' judgement & Description \\
\hline Adequate sequence generation? & Unclear & Not reported \\
\hline Allocation concealment? & Unclear & Not reported \\
\hline $\begin{array}{l}\text { Blinding? } \\
\text { All outcomes }\end{array}$ & Yes & Double blind \\
\hline
\end{tabular}


Koenig 2008 (Continued)

\begin{tabular}{l|l|l}
\hline $\begin{array}{l}\text { Incomplete outcome data addressed? } \\
\text { All outcomes }\end{array}$ & Yes & $321 / 466(69 \%)$ completed the study \\
\hline Free of selective reporting? & Yes & Full data on GSK web site \\
\hline
\end{tabular}

\section{Koopmans 2006}

\begin{tabular}{|c|c|c|}
\hline Methods & \multicolumn{2}{|c|}{$\begin{array}{l}\text { A randomized, double-blind, single-centre, parallel-group study over } 12 \text { months from } \\
\text { September } 2000 \text { to December } 2003 \text { in the Netherlands. Run-in } 4 \text { weeks } \\
\text { A study to compare the long term effects on airway inflammation of Seretide versus } \\
\text { Flixotide in adult subjects with asthma }\end{array}$} \\
\hline Participants & \multicolumn{2}{|c|}{$\begin{array}{l}\text { Population: } 54 \text { adults (19-59) with mild to moderate persistent allergic asthma. } \\
\text { Baseline Characteristics: Mean age } 32 \text { years. } \mathrm{FEV}_{1} 89 \% \text { predicted. Concomitant in- } \\
\text { haled corticosteroids used by } 100 \% \text { of participants (Median dose } 600 \mathrm{mcg} / \text { day). } \\
\text { Inclusion Criteria:aged between } 18 \text { and } 50 \text { years with reversible airways obstruction, } \\
\text { informed consent, allergic to house dust mite, } \mathrm{PC}_{20} \text { histamine }<8 \mathrm{mg} / \mathrm{ml}, \mathrm{FEV}_{1} \text { greater } \\
\text { than } 70 \% \text { predicted. } \\
\text { Exclusion Criteria: serious concurrent disease likely to interfere with the study, lower } \\
\text { respiratory tract infection, or use of antibiotics in the previous } 4 \text { weeks }\end{array}$} \\
\hline Interventions & \multicolumn{2}{|c|}{$\begin{array}{l}\text { 1. FSC } 250 / 50 \mu \mathrm{gBD} \\
\text { 2. FP } 250 \mu \mathrm{gD} \\
\text { Delivery was Diskus device }\end{array}$} \\
\hline Outcomes & \multicolumn{2}{|c|}{$\begin{array}{l}\text { The primary efficacy variables were the percentage of eosinophils and eosinophil cationic } \\
\text { protein (ECP) in induced sputum (baseline and after allergen challenge) at randomisation } \\
\text { and } 1,36,9 \text { and } 11 \text { months later }\end{array}$} \\
\hline \multicolumn{3}{|l|}{ Notes } \\
\hline \multicolumn{3}{|l|}{ Risk of bias } \\
\hline Item & Authors' judgement & Description \\
\hline Adequate sequence generation? & Unclear & Not reported \\
\hline Allocation concealment? & Unclear & Not reported \\
\hline $\begin{array}{l}\text { Blinding? } \\
\text { All outcomes }\end{array}$ & Yes & Double blind \\
\hline $\begin{array}{l}\text { Incomplete outcome data addressed? } \\
\text { All outcomes }\end{array}$ & Yes & $50 / 54(93 \%)$ completed the study \\
\hline Free of selective reporting? & Yes & Data on GSK website \\
\hline
\end{tabular}




\begin{tabular}{|c|c|c|}
\hline Methods & \multicolumn{2}{|c|}{$\begin{array}{l}\text { A randomized, double-blind, parallel-group study over } 12 \text { months from August } 1997 \text { to } \\
\text { December } 2002 \text { in Sweden. Run-in } 2 \text { months } \\
\text { An interventional three year study for asthma control - In what way and in what kind of } \\
\text { population is it possible to get asthmatic patients free from symptoms, keep the patients } \\
\text { in work, restore a normal lung function, diminish hyperreactivity and normalise quality } \\
\text { of life? }\end{array}$} \\
\hline Participants & \multicolumn{2}{|c|}{$\begin{array}{l}\text { Population: } 282 \text { adults (18-70) with mild to moderate persistent asthma. } \\
\text { Baseline Characteristics: Mean age } 40 \text { years. } \mathrm{FEV}_{1} 93 \% \text { predicted. Concomitant in } \\
\text { haled corticosteroids used by } 68 \% \text { of participants. } \\
\text { Inclusion Criteria:clinically representative mild to moderate asthma, symptoms, or use } \\
\text { of rescue medication at least twice a week, required to have airway hyperreactivity (AHR) } \\
\text { demonstrated by methacholine challenge with a PC } 20 \text { (the concentration required to } \\
\text { provoke a } 20 \% \text { reduction in FEV } 1 \text { ) }<8 \mathrm{mg} / \mathrm{ml} \text {. If AHR was not demonstrated via metha- } \\
\text { choline challenge then one of the following: diurnal variability in peak expiratory flow } \\
\text { (PEF) of at least } 20 \% \text { on }>3 \text { days during the last } 14 \text { days of the run-in; at least } 30 \% \\
\text { difference between the highest and lowest PEF reading during any } 7 \text { days in the run-in } \\
\text { period; or an increase of at least } 15 \% \text { in FEV1 or PEF after salbutamol inhalation }(0.8 \\
\text { mg). } \\
\text { Exclusion Criteria: taking daily doses of ICS greater than } 1200 \mu \text { g, had experienced } \\
\text { one or more life-threatening exacerbation requiring hospitalisation during the previous } \\
12 \text { months, were hypersensitive to beta-agonists or ICS, were pregnant or lactating or } \\
\text { had a respiratory tract infection during the } 4 \text { weeks prior to run-in }\end{array}$} \\
\hline Interventions & \multicolumn{2}{|c|}{$\begin{array}{l}\text { 1. FSC } 250 / 50 \mu \mathrm{g} \text { BD } \\
\text { 2. FP } 250 \mu \mathrm{gBD} \\
\text { 3. Sal } 50 \mu \mathrm{g} \text { BD } \\
\text { Delivery was Diskus device (arm three was not used in this review) }\end{array}$} \\
\hline Outcomes & \multicolumn{2}{|c|}{$\begin{array}{l}\text { The primary efficacy variable was the requirement for an increased dose of study medi- } \\
\text { cation }\end{array}$} \\
\hline \multicolumn{3}{|l|}{ Notes } \\
\hline \multicolumn{3}{|l|}{ Risk of bias } \\
\hline Item & Authors' judgement & Description \\
\hline Adequate sequence generation? & Unclear & Not reported \\
\hline Allocation concealment? & Unclear & Not reported \\
\hline $\begin{array}{l}\text { Blinding? } \\
\text { All outcomes }\end{array}$ & Yes & Double blind \\
\hline $\begin{array}{l}\text { Incomplete outcome data addressed? } \\
\text { All outcomes }\end{array}$ & Yes & $263 / 282(93 \%)$ completed the study \\
\hline Free of selective reporting? & Yes & Data on GSK web site \\
\hline
\end{tabular}




\begin{tabular}{|c|c|c|}
\hline Methods & \multicolumn{2}{|c|}{$\begin{array}{l}\text { A randomized, double-blind, active-controlled, multicenter, parallel-group study over } 12 \\
\text { weeks from April } 2002 \text { to January } 2003 \text { at } 79 \text { centres. ( } 66 \text { in the US and } 13 \text { in Canada) } \\
\text {. Run-in } 2 \text { weeks. }\end{array}$} \\
\hline Participants & \multicolumn{2}{|c|}{$\begin{array}{l}\text { Population: } 203 \text { children(4-11) years with persistent asthma. } \\
\text { Baseline Characteristics: Mean age } 8 \text { years. } \mathrm{FEV}_{1} \text { mean } 80 \% \text { predicted. (6-11 y) PEFR } \\
\text { mean } 87 \% \text { predicted. ( } 4-5 \mathrm{y} \text { ) } \\
\text { Concomitant inhaled corticosteroids used by } 100 \% \text { of participants. } \\
\text { Inclusion Criteria: } 4-11 \text { years of age diagnosed with asthma (ATS definition), who } \\
\text { required physician-prescribed treatment for at least } 2 \text { months and taking an inhaled } \\
\text { corticosteroid for asthma for at least one month prior to visit } 1 \\
\mathrm{FEV}_{1} \% \text { predicted between } 50 \% \text { to } 95 \% \text { ( } 6-11 \mathrm{y} \text { ), am PEFR } \% \text { predicted between } 50 \% \\
\text { to } 95 \% \text { ( } 4-5 \mathrm{y} \text { ). Bronchodilator reversibility by an increase of at least } 12 \% \text { in } \mathrm{FEV}_{1}(6-11 \\
\text { yr) or am PEFR ( } 4-5 \text { yr) over baseline within } 30 \text { minutes of } 2-4 \text { actuations of albutero } \\
(180-360 \mu \mathrm{g} \text { ) or to have historical documentation of } 12 \% \text { or greater reversibility within } \\
\text { the previous year. } \\
\text { Exclusion Criteria: history of life-threatening asthma, hospitalization due to asthma } \\
\text { twice or more in the previous year, significant concurrent disease (e.g. cystic fibrosis, ma- } \\
\text { lignancy or immunologic compromise), recent upper or lower respiratory tract infection, } \\
\text { current chickenpox or recent exposure to chickenpox in a nonimmune patient, severe } \\
\text { milk protein allergy, hypersensitivity to } \mathrm{B}_{2} \text {-agonist, sympathomimetic or corticosteroid } \\
\text { therapy, clinically significant abnormal laboratory test results }\end{array}$} \\
\hline Interventions & \multicolumn{2}{|c|}{$\begin{array}{l}\text { 1. FSC } 100 / 50 \mu \mathrm{gBD} \\
\text { 2. FP } 100 \mu \mathrm{g} \text { BD } \\
\text { Delivery was Diskus device }\end{array}$} \\
\hline Outcomes & \multicolumn{2}{|c|}{$\begin{array}{l}\text { This was a safety study and no primary efficacy endpoint was identified } \\
\text { No SAE occurred in this study. }\end{array}$} \\
\hline \multicolumn{3}{|l|}{ Notes } \\
\hline \multicolumn{3}{|l|}{ Risk of bias } \\
\hline Item & Authors' judgement & Description \\
\hline Adequate sequence generation? & Unclear & Not reported \\
\hline Allocation concealment? & Unclear & Not reported \\
\hline $\begin{array}{l}\text { Blinding? } \\
\text { All outcomes }\end{array}$ & Yes & Double blind \\
\hline $\begin{array}{l}\text { Incomplete outcome data addressed? } \\
\text { All outcomes }\end{array}$ & Yes & $168 / 203(83 \%)$ completed the study \\
\hline Free of selective reporting? & Yes & Full data on GSK web site \\
\hline
\end{tabular}


Murray 2004

Methods

Participants

A randomized, double-blind, active-controlled, multicenter, parallel-group study over 12 weeks from November 1999 to September 2000 at 33 centres in the US. Run in 2 weeks single blind placebo

Baseline Characteristics: Mean age 34 years. $\mathrm{FEV}_{1} 66 \%$ predicted. Concomitant in-
haled corticosteroids used by $0 \%$ of participants.
Inclusion Criteria: 12 years or older with a 6 months history of asthma and must have
been treated with as-needed, short-acting, inhaled beta2-agonists alone during the pre-
vious month with no oral or inhaled corticosteroid use within one month or long-acting
beta-agonist within 72 hours of study entry
$\begin{aligned} & \mathrm{FEV}, \% \text { predicted between } 40 \% \text { to } 85 \% \text {, bronchodilator reversibility by an increase of } \\ & \text { at least } 15 \% \text { in } \mathrm{FEV}_{1} \text { over baseline within } 30 \text { minutes of inhalation of } 2 \text { puffs }(180 \mu \mathrm{g}) \\ & \text { of albuterol. } \\ & \text { Exclusion Criteria: Pregnancy and/or lactation,life-threatening asthma, hospitalization } \\ & \text { attributable to asthma twice or more in the last year, current smoker or a more than } 10 \\ & \text { pack-year history of smoking, significant concurrent diseases including a recent upper } \\ & \text { or lower respiratory tract infection. Medications prohibited before and throughout the } \\ & \text { study included inhaled, oral or parenteral corticosteroids, theophylline or other bron- } \\ & \text { chodilators, anticholinergics, leukotriene modifiers, cromolyn and nedocromil }\end{aligned}$

\begin{tabular}{l|l}
\hline Interventions & 1. FSC $100 / 50 \mu \mathrm{g} \mathrm{BD}$ \\
2. FP $100 \mu \mathrm{g} \mathrm{BD}$ \\
Delivery Diskus
\end{tabular}

Outcomes

Two primary efficacy variables were defined: (1) mean change from baseline in AM predose $\mathrm{FEV}_{1}$ at endpoint for FSC 100/50 compared to SALM 50, (2) area under the serial $\mathrm{FEV}_{1}$ curve at treatment week 12 relative to treatment day 1 baseline for FSC 100/ 50 compared to FP 100

Notes

Risk of bias

\begin{tabular}{lll}
\hline Item & Authors' judgement & Description \\
\hline Adequate sequence generation? & Yes & $\begin{array}{l}\text { Treatment assignments were generated in } \\
\text { blocks of } 6 \text { by a computer-based random } \\
\text { codes system }\end{array}$ \\
\hline Allocation concealment? & Unclear & Not stated \\
\hline $\begin{array}{l}\text { Blinding? } \\
\text { All outcomes }\end{array}$ & Yes & Double blind \\
\hline $\begin{array}{l}\text { Incomplete outcome data addressed? } \\
\text { All outcomes }\end{array}$ & Yes & 228/267 (85\%) completed the study \\
\hline Free of selective reporting? & Yes & Full data on GSK web site \\
\hline
\end{tabular}


Nathan 2006

\begin{tabular}{|c|c|c|}
\hline Methods & \multicolumn{2}{|c|}{ Parallel group Multicentre study over 12 weeks., } \\
\hline Participants & \multicolumn{2}{|c|}{$\begin{array}{l}365 \text { adults and adolescents randomised. Age range: } 12-82 \text { years, mean FEV1 } 68 \% \text { pre- } \\
\text { dicted. Inclusion criteria: FP } 440-660 \mathrm{mcg} / \mathrm{d} \text { for at least } 3 \text { months prior to study entry; } \\
\text { FEV1 } 40-85 \% \text {; reversibility > }=15 \%\end{array}$} \\
\hline Interventions & \multicolumn{2}{|c|}{$\begin{array}{l}\text { Combination HFA FP/SAL } 110 / 42 \text { BID (220/84) versus CFC SAL } 42 \text { BID (84) versus } \\
\text { CFC FP } 110 \text { BID (220) versus HFA PLA. Inhaler devices: MDI. Run-in: } 2 \text { weeks } \\
\text { This review only includes data from the salmeterol and placebo arms. } \\
\text { Co-interventions: ICS at usual dose was an inclusion criterion, but appears to have been } \\
\text { withdrawn in the Salmeterol and Placebo arms of the study }\end{array}$} \\
\hline Outcomes & \multicolumn{2}{|c|}{$\begin{array}{l}\text { The paper publication mentions one drug-related SAE (an upper GI bleed from the } \\
\text { placebo group). } \\
\text { Website: SAS30004. No fatal SAE. No SAE on FSC or FP }\end{array}$} \\
\hline \multicolumn{3}{|l|}{ Notes } \\
\hline \multicolumn{3}{|l|}{ Risk of bias } \\
\hline Item & Authors' judgement & Description \\
\hline Adequate sequence generation? & Unclear & Not stated \\
\hline Allocation concealment? & Unclear & Not stated \\
\hline $\begin{array}{l}\text { Blinding? } \\
\text { All outcomes }\end{array}$ & Yes & Double blind \\
\hline $\begin{array}{l}\text { Incomplete outcome data addressed? } \\
\text { All outcomes }\end{array}$ & Yes & $\begin{array}{l}243 / 365(67 \%) \text { completed the study, no } \\
\text { SAE events occurred }\end{array}$ \\
\hline Free of selective reporting? & Yes & Full data on GSK web site \\
\hline
\end{tabular}

Nelson 2003

Methods

Participants
Randomized, double-blind, active-controlled, parallel-group study over 12 weeks at 33 centres in the U.S. Run in 2 weeks single blind placebo

Population: 283 adolescents and adults (12-77) years with asthma.

Baseline Characteristics: Mean age 32 years. FEV $_{1} 66 \%$ predicted.

Concomitant inhaled corticosteroids used by zero percentage of participants.

Inclusion Criteria: At least 12 years old and a medical history of asthma, (as defined by the American Thoracic Society) requiring asthma pharmacotherapy for at least 6 months, $\mathrm{FEV}_{1} \%$ predicted between $40 \%$ to $85 \%$, bronchodilator reversibility by an increase of at least $15 \%$ in $\mathrm{FEV}_{1}$ over baseline within 30 minutes after two inhalations of inhaled albuterol. $(180 \mu \mathrm{g})$

Exclusion Criteria: History of life-threatening asthma; hypersensitivity reaction to sympathomimetic drugs or corticosteroids; smoking within the previous year or a history 
Nelson 2003 (Continued)

\begin{tabular}{|c|c|c|}
\hline & \multicolumn{2}{|c|}{$\begin{array}{l}\text { of }>10 \text { pack-years; use of oral, inhaled or injectable corticosteroid therapy within the } \\
\text { previous month; use of intranasal corticosteroid therapy except for Flonase (GlaxoW- } \\
\text { ellcome Inc.); use of daily oral corticosteroid treatment within the previous } 6 \text { months; } \\
\text { use of any other prescription or over-the-counter medication that could have affected } \\
\text { the course of asthma or interacted with sympathomimetic amines; abnormal chest x-ray } \\
\text { films; clinically significant abnormal 12-lead electrocardiograms (ECGs); or a history of } \\
\text { significant concurrent disease (e.g., glaucoma, diabetes, hypertension) }\end{array}$} \\
\hline Interventions & \multicolumn{2}{|c|}{$\begin{array}{l}\text { 1. FSC } 88 / 44 \mu \mathrm{g} \text { HFA BD } \\
\text { 2. FP } 88 \mu \mathrm{g} \text { CFC BD } \\
\text { 3. Salmeterol } 42 \mu \mathrm{g} \text { CFC BD (not considered in this review) } \\
\text { Delivery was MDI }\end{array}$} \\
\hline Outcomes & \multicolumn{2}{|c|}{$\begin{array}{l}\text { Primary efficacy measures were area under the serial Forced Expiratory Flow } \mathrm{FEV}_{1} \text { curve } \\
\text { for } 12 \text { hours following administration of study medication and change from baseline at } \\
\text { endpoint in morning pre-dose } \mathrm{FEV}_{1} \\
\text { The paper reports "no serious drug related adverse events". }\end{array}$} \\
\hline \multicolumn{3}{|l|}{ Notes } \\
\hline \multicolumn{3}{|l|}{ Risk of bias } \\
\hline Item & Authors' judgement & Description \\
\hline Adequate sequence generation? & Unclear & Not reported \\
\hline Allocation concealment? & Unclear & Not reported \\
\hline $\begin{array}{l}\text { Blinding? } \\
\text { All outcomes }\end{array}$ & Yes & Double blind \\
\hline $\begin{array}{l}\text { Incomplete outcome data addressed? } \\
\text { All outcomes }\end{array}$ & Yes & $257 / 283(91 \%)$ completed the study \\
\hline Free of selective reporting? & Yes & Full data on GSK web site \\
\hline
\end{tabular}

Pearlman 2004

Methods

Setting: Multicentre study, USA

Length of intervention period: 12 weeks

Randomisation: yes (method not reported)

Allocation concealment: not stated

Design: parallel group

Masking: double blind

Excluded: not stated

Withdrawals: not stated (ITT) 


\begin{tabular}{|c|c|c|}
\hline Participants & \multicolumn{2}{|c|}{$\begin{array}{l}\mathrm{N}=360 \text {. FPS arm N }=92, \mathrm{FP} \text { arm } \mathrm{N}=89 \text {. } \\
\text { Study Population: Males and females } 12 \text { years of age or older, with a diagnosis of asthma } \\
\text { using the American Thoracic Society definition were screened. All subjects were required } \\
\text { to have a FEV1 of } 40 \% \text { to } 85 \% \text { predicted normal and }>15 \% \text { reversibility following } \\
2 \text { puffs of VENTOLIN at Screening. The study population was stratified according } \\
\text { to whether or not subjects were treated with inhaled corticosteroids or inhaled beta2- } \\
\text { agoinsts at Screening (salmeterol or short-acting beta2-agonists only). Subjects treated } \\
\text { with inhaled corticosteroids must have been treated for at least } 3 \text { months prior to Visit } 1 \\
\text { and receiving a daily dose of: } 252-336 \text { mcg beclomethasone dipropionate, } 600-800 \mathrm{mcg} \\
\text { triamcinolone acetonide, } 1000 \text { mcg flunisolide, } 400-600 \text { mcg budesonide, } 176 \mathrm{mcg} \text { fluti- } \\
\text { casone propionate inhalation aerosol or } 200 \mathrm{mcg} \text { FP inhalation powder for at least one } \\
\text { month prior to Visit } 1 \text { with no change in regimen. Eligible subjects using only, as-needed, } \\
\text { short-acting beta-agonist therapy were required to have received treatment for at least } \\
\text { one week prior to Visit } 1 \text { and have a } 7 \text { day total symptom score }>7 \text { for the } 7 \text { days prior } \\
\text { to Visit } 2 \text {. Eligible subjects using salmeterol at baseline were required to have received } \\
\text { salmeterol and as-needed, short-acting beta2-agonists only for at least one week prior to } \\
\text { Visit } 1 \\
\text { No details on distribution between the groups provided. Participants described as symp- } \\
\text { tomatic. Baseline medication: prn SABA alone: } 142 \text {; SAL: } 84 \text {; ICS: } 134 \text { (37\%) }\end{array}$} \\
\hline Interventions & \multicolumn{2}{|c|}{$\begin{array}{l}\text { 1. FSC } 88 / 42 \text { bd } \\
\text { 2. Fluticasone } 88 \text { bd } \\
\text { The other arms were not used for this review. }\end{array}$} \\
\hline Outcomes & \multicolumn{2}{|c|}{$\begin{array}{l}\text { Paper reports no serious drug-related adverse events. } \\
\text { Website:SAS3003. No fatal SAE in the FPS or FP group. One Tachyarrythmia on FP }\end{array}$} \\
\hline \multicolumn{3}{|l|}{ Notes } \\
\hline \multicolumn{3}{|l|}{ Risk of bias } \\
\hline Item & Authors' judgement & Description \\
\hline Adequate sequence generation? & Unclear & Not stated \\
\hline Allocation concealment? & Unclear & Not stated \\
\hline $\begin{array}{l}\text { Blinding? } \\
\text { All outcomes }\end{array}$ & Yes & Double blind \\
\hline $\begin{array}{l}\text { Incomplete outcome data addressed? } \\
\text { All outcomes }\end{array}$ & Unclear & $279 / 360(77 \%)$ completed study \\
\hline Free of selective reporting? & Yes & Data on GSK web site \\
\hline
\end{tabular}




$\begin{array}{ll}\text { Methods } & \text { A randomized, double-blind, multicenter, parallel-group study over } 12 \text { weeks from } \\ \text { February } 2003 \text { to September } 2003 \text { at } 48 \text { centres worldwide. ( Argentina } \\ \text { (4), Czech Republic (8), France(9), Israel (4), Italy (9), Poland(4), Slovakia (6), Turkey } \\ \text { (4) Run in } 2 \text { weeks }\end{array}$

Participants

Population: 362 adolescents and adults $(12$ - 78) years with moderate persistent asthma Baseline Characteristics: Mean age 41 years. $\mathrm{FEV}_{1} 72 \%$ predicted.Concomitant inhaled corticosteroids used by $0 \%$ of participants.

Inclusion Criteria: 12 to 80 years with a documented clinical history of persistent asthma for at least 6 months and currently receiving inhaled short-acting â2-agonists alone. $\mathrm{FEV}_{1} \%$ predicted between $60 \%$ and $80 \%$,bronchodilator reversibility by an increase of at least $15 \%$ in $\mathrm{FEV}_{1}$ over baseline after $400 \mu \mathrm{g}$ salbutamol, or a mean morning PEF during the last 7 days of the run-in of less than $85 \%$ of the post-bronchodilator value, and a daytime symptom score of at least 2 on at least 4 of the last 7 days of the run-in

Exclusion Criteria: Taken corticosteroids within 12 weeks, leukotriene receptor antagonists within 4 weeks or long acting inhaled or oral â2-agonists, sodium cromoglycate, nedocromil sodium, ketotifen, methylxanthines, or

inhaled anticholinergics within 2 weeks of entering the study, or had an acute asthma exacerbation requiring hospital treatment within 6 weeks, or had a respiratory tract infection within 4 weeks of entering the study, or a smoking history of more than 10 pack years

\begin{tabular}{l|l}
\hline Interventions & 1. FSC $250 / 50 \mu \mathrm{g}$ BD \\
2. FP $250 \mu \mathrm{g}$ BD \\
Delivery was Diskus inhaler
\end{tabular}

Outcomes

Primary efficacy variable was mean morning PEF.

Paper reports: "Only three serious adverse events occurred and none were considered related to study treatment."

Notes

Risk of bias

\begin{tabular}{|c|c|c|}
\hline Item & Authors' judgement & Description \\
\hline Adequate sequence generation? & Unclear & Not reported \\
\hline Allocation concealment? & Unclear & Not reported \\
\hline $\begin{array}{l}\text { Blinding? } \\
\text { All outcomes }\end{array}$ & Yes & Double blind \\
\hline $\begin{array}{l}\text { Incomplete outcome data addressed? } \\
\text { All outcomes }\end{array}$ & Yes & $350 / 362(97 \%)$ completed the study \\
\hline Free of selective reporting? & Yes & Full data on GSK web site \\
\hline
\end{tabular}




\begin{tabular}{|c|c|c|}
\hline Methods & \multicolumn{2}{|c|}{$\begin{array}{l}\text { A randomized, double-blind, multi centre, parallel-group study over } 30 \text { weeks from } \\
\text { September } 2000 \text { to May } 2002 \text { at } 5 \text { centres in Denmark. Run-in } 2 \text { weeks } \\
\text { A multi centre, randomised, double-blind, controlled, parallel-group, comparative in- } \\
\text { vestigation of the corticosteroid-saving potential of the combination therapy fluticasone } \\
\text { propionate and salmeterol (SERETIDE) compared with fluticasone propionate alone, } \\
\text { given to adult asthmatic subjects, when reducing the inhaled corticosteroid dose from } \\
\text { an initially high level of } 500 \mu \mathrm{g} \text { bd }\end{array}$} \\
\hline Participants & \multicolumn{2}{|c|}{$\begin{array}{l}\text { Population: } 61 \text { adults }(18+) \text { with stable asthma. } \\
\text { Baseline Characteristics: Mean age } 37 \text { years. } \mathrm{FEV}_{1} \text { not reported \% predicted. Con- } \\
\text { comitant inhaled corticosteroids used by } 100 \% \text { of participants. } \\
\text { Inclusion Criteria: At least } 18 \text { years old with a clinical diagnosis of stable asthma, treated } \\
\text { with } 1500-2000 \mu \text { g of budesonide, beclomethasone dipropionate or flunisolide, or } 750 \\
1000 \mu \text { g of FP for at least } 10 \text { weeks prior to the study. } \mathrm{FEV}_{1} \% \text { predicted at least } 60 \% \text {, } \\
\text { need to be able to use the data capture method (electronic diary, AM-2) correctly. } \\
\text { Exclusion Criteria: not reported }\end{array}$} \\
\hline Interventions & \multicolumn{2}{|c|}{$\begin{array}{l}\text { 1. FSC } 500 / 50,250 / 50 \text { or } 100 / 50 \mu \mathrm{g} \mathrm{BD} \\
\text { 2. FP } 500,250 \text { or } 100 \mu \mathrm{g} \mathrm{BD}\end{array}$} \\
\hline Outcomes & \multicolumn{2}{|c|}{$\begin{array}{l}\text { The primary efficacy endpoint was the minimum dose at which the subject's asthma } \\
\text { remained controlled ? the minimum acceptable dose (MAD) }\end{array}$} \\
\hline \multicolumn{3}{|l|}{ Notes } \\
\hline \multicolumn{3}{|l|}{ Risk of bias } \\
\hline Item & Authors' judgement & Description \\
\hline Adequate sequence generation? & Unclear & Not reported \\
\hline Allocation concealment? & Unclear & Not reported \\
\hline $\begin{array}{l}\text { Blinding? } \\
\text { All outcomes }\end{array}$ & Yes & Double blind \\
\hline $\begin{array}{l}\text { Incomplete outcome data addressed? } \\
\text { All outcomes }\end{array}$ & Yes & $55 / 61(90 \%)$ completed the study \\
\hline Free of selective reporting? & Yes & Data on GSK web site \\
\hline
\end{tabular}




A multi-centre, randomised, double-blind, placebo-controlled parallel group study to
compare the effect on airway inflammation and remodelling of treatment with salme-
terol/fluticasone propionate combination product $(50 / 100 \mathrm{mcg}$ strength) bd via the $A c-$
cuhaler inhaler, or fluticasone propionate $100 \mathrm{mcg}$ bd via the Accuhaler inhaler or placebo
via the Accuhaler inhaler for 16 weeks, followed by double-blind treatment for 52 weeks
with the salmeterol/fluticasone propionate combination product $(50 / 100 \mathrm{mcg}$ strength)
bd via the Accuhaler inhaler or fluticasone propionate $100 \mathrm{mcg}$ bd via the Accuhaler
inhaler, in adults with reversible airways obstruction (SIRIAS - Seretide in Inflammation
and Remodelling In Asthma Study)

\begin{tabular}{|c|c|}
\hline Participants & $\begin{array}{l}\text { Population: } 63 \text { adults }(18 \text { - } 50 \text { ) with mild asthma. } \\
\text { Baseline Characteristics: Mean age } 32 \text { years. } \mathrm{FEV}_{1} \text { unknown } \% \text { predicted. Concomitant } \\
\text { inhaled corticosteroids used by unknown } \% \text { of participants, but all withdrawn during } \\
\text { the run-in period. } \\
\text { Inclusion Criteria: Aged } 18 \text { to } 50 \text { years with a history of reversible airways obstruction, } \\
\text { to have received short-acting beta } 2 \text { - agonist alone or Beclometasone dipropionate or } \\
\text { budesonide at a constant daily dose of up to } 400 \text { mcg per day (excluding any CFC-free } \\
\text { formulation) or FP at a constant daily dose of up to } 200 \mathrm{mcg} \text { per day via any device for } \\
\text { at least four weeks prior to the first visit. In addition subjects were to have had a fall in } \\
\text { FEV } \mathrm{V}_{1} \text { of at least } 20 \% \text { with a histamine challenge test at the first visit and have a post- } \\
\text { bronchodilator FEV } \mathrm{F}_{1} \text { of }>60 \% \text { of predicted normal. To be randomised subjects had to } \\
\text { have a fall in FEV } \mathrm{V}_{1} \text { of at least } 20 \% \text { with a standardised histamine challenge test, AND at } \\
\text { least one of the following criteria: have recorded symptoms on at least } 4 \text { of the last seven } \\
\text { days of the preventer-free run-in period; have recorded using their inhaled short-acting } \\
\text { beta } 2 \text {-agonist on at least } 2 \text { occasions on at least } 4 \text { of the last seven days of the preventer- } \\
\text { free run-in period; have a period variation of at least } 10 \% \text { over the last seven days of the } \\
\text { preventer-free run-in period. } \\
\text { Exclusion Criteria: not reported }\end{array}$ \\
\hline
\end{tabular}

Interventions

1. FSC $100 / 50 \mu \mathrm{g}$ BD throughout

2. Placebo initially and then FSC $100 / 50 \mu \mathrm{g} B D$

3. FP100 $\mu \mathrm{g}$ BD throughout

Delivery as DPI

Outcomes

Outcome: The primary efficacy endpoint was the level of airway hyper-reactivity (as measured by histamine $\mathrm{PC}_{20}$ ) and response of the induced airway spasm to bronchodilator (post-bronchodilator forced expiratory volume in one second $\left(\mathrm{FEV}_{1}\right)$ )

SAE data was used for the 52 week extension period as reported. There were no SAEs reported in the 16 week initial period

Notes

Risk of bias

\begin{tabular}{lll}
\hline Item & Authors' judgement & Description \\
\hline Adequate sequence generation? & Unclear & Not reported \\
\hline Allocation concealment? & Unclear & Not reported
\end{tabular}

Regular treatment with salmeterol and inhaled steroids for chronic asthma: serious adverse events (Review) 
SAM40004 (Continued)

\begin{tabular}{l|l|l}
\hline $\begin{array}{l}\text { Blinding? } \\
\text { All outcomes }\end{array}$ & Yes & Double blind \\
\hline $\begin{array}{l}\text { Incomplete outcome data addressed? } \\
\text { All outcomes }\end{array}$ & No & $37 / 63(59 \%)$ completed the study \\
\hline Free of selective reporting? & Yes & Data on GSK web site \\
\hline
\end{tabular}

\section{SAM40008}

$\begin{array}{ll}\text { Methods } & \begin{array}{l}\text { A Multicentre, Randomised, Double-Blind, Parallel Group Comparison of the Efficacy of } \\ \text { SERETIDE* bd and Fluticasone Propionate bd (Both Via DISKUS*/ACCUHALER*, } \\ \text { Inhaler) when Tapering the Inhaled Corticosteroid Dose in Asthmatic Adults }\end{array} \\ \text { Carried out over } 26 \text { weeks from May } 2000 \text { to July } 2001 \text { at } 34 \text { centres in } 10 \text { countries } \\ \text { (Australia, Estonia, Finland, France, Germany, Israel, Latvia, New Zealand, Spain, the } \\ \text { United Kingdom) }\end{array}$

\begin{tabular}{ll}
\hline Participants & $\begin{array}{l}\text { Population: } 186 \text { adults }(18+) \text { with persistent asthma. } \\
\text { Baseline Characteristics: Mean age } 50 \text { years. FEV } \mathrm{FE}_{1} \text { unknown \% predicted. Concomi- } \\
\text { tant inhaled corticosteroids used by } 100 \% \text { of participants. } \\
\text { Inclusion Criteria: } 18 \text { years or older with documented evidence of asthma within the } \\
\text { previous } 2 \text { years and who were receiving } 1500-2000 \mathrm{mcg} / \text { day of BUD or equivalent ICS, } \\
\text { excluding FP, for at least } 3 \text { months prior to the start of baseline. } \\
\text { Exclusion Criteria: not reported }\end{array}$ \\
\hline
\end{tabular}

\begin{tabular}{l|l} 
Interventions & 1. FSC $500 / 50 \mu \mathrm{g} \mathrm{BD}$ \\
2. FP $500 \mu \mathrm{gDD}$ \\
Delivery as DPI
\end{tabular}

\begin{tabular}{l|l} 
Outcomes & The primary efficacy endpoint was the minimum acceptable daily dose of ICS \\
\hline Notes & High drop-out rate. Only $8 \%$ completed the study \\
\hline
\end{tabular}

\section{Risk of bias}

\begin{tabular}{lll}
\hline Item & Authors' judgement & Description \\
\hline Adequate sequence generation? & Unclear & Not reported \\
\hline Allocation concealment? & Unclear & Not reported \\
\hline $\begin{array}{l}\text { Blinding? } \\
\text { All outcomes }\end{array}$ & Yes & Double blind \\
\hline
\end{tabular}

Incomplete outcome data addressed? No only $14 / 186(8 \%)$ completed the study

All outcomes 
SAM40008 (Continued)

\begin{tabular}{|c|c|c|}
\hline Free of selective reporting? & Yes & Data on GSK web site \\
\hline
\end{tabular}

\section{SAM40012}

$\begin{array}{ll}\text { Methods } & \text { A randomized, double-blind, double-dummy, multi centre, parallel-group study over } \\ 24 \text { weeks from June } 2000 \text { to June } 2001 \text { at } 38 \text { centres in } 7 \text { countries. (Bulgaria, Hungary, } \\ \text { Israel, Poland, Russia, Spain, the United Kingdom) Run-in } 2 \text { weeks } \\ \text { A multi centre, randomised, double-blind, double-dummy, parallel group comparison } \\ \text { of three treatments : 1) salmeterol/fluticasone propionate (SFC) (50/100mcg strength) } \\ \text { bd via DISKUS/ACCUHALER inhaler, 2) fluticasone propionate 200mcg bd via } \\ \text { DISKUS/ACCUHALER inhaler, 3) fluticasone propionate } 100 \mathrm{mcg} \text { bd via DISKUS/ } \\ \text { ACCUHALER inhaler in children aged 4-11 years with asthma }\end{array}$

Participants

Population: 548 children $(4-11)$ with asthma.

Baseline Characteristics: Mean age 8 years. $\mathrm{FEV}_{1}$ not reported \% predicted. Concomitant inhaled corticosteroids used by $100 \%$ of participants.

Inclusion Criteria: Aged 4-11 years, inclusive, with documented evidence of asthma and receiving BDP, BUD or equivalent at a dose of $400-500 \mathrm{mcg} /$ day or fluticasone propionate at a dose of $200-250 \mathrm{mcg} /$ day for at least 4 weeks before Visit 1 . Recorded a symptom score (i.e. total score of daytime and night-time scores) on the electronic daily record card of at least 2 on at least three of the last seven consecutive days of the runin period and had a mean morning PEF (calculated from the last 7 days of the run-in period) of between $50 \%$ and $85 \%$ of the PEF measured 15 minutes after administration of $400 \mathrm{mcg}$ of salbutamol at the randomisation visit. In addition, subjects had to have recorded at least $70 \%$ of data into their electronic daily record cards.

Exclusion Criteria: not reported

\begin{tabular}{|c|c|c|}
\hline Interventions & \multicolumn{2}{|c|}{$\begin{array}{l}\text { 1. FSC } 100 / 50 \mu \mathrm{g} \mathrm{BD} \\
\text { 2. FP } 100 \mu \mathrm{g} \mathrm{BD} \\
\text { 3. FP } 200 \mu \mathrm{g} \mathrm{BD} \\
\text { Delivery was Diskus device (third arm not used in this review) }\end{array}$} \\
\hline Outcomes & \multicolumn{2}{|c|}{$\begin{array}{l}\text { The primary efficacy endpoint was the percentage of combined symptom-free days and } \\
\text { nights during weeks 1-24 }\end{array}$} \\
\hline \multicolumn{3}{|l|}{ Notes } \\
\hline \multicolumn{3}{|l|}{ Risk of bias } \\
\hline Item & Authors' judgement & Description \\
\hline Adequate sequence generation? & Unclear & Not reported \\
\hline Allocation concealment? & Unclear & Not reported \\
\hline $\begin{array}{l}\text { Blinding? } \\
\text { All outcomes }\end{array}$ & Yes & Double blind \\
\hline
\end{tabular}


SAM40012 (Continued)

\begin{tabular}{l|l|l}
\hline $\begin{array}{l}\text { Incomplete outcome data addressed? } \\
\text { All outcomes }\end{array}$ & Yes & $513 / 548(94 \%)$ completed the study \\
\hline Free of selective reporting? & Yes & Data on GSK web site \\
\hline
\end{tabular}

\section{SAM40031}

\begin{tabular}{ll} 
Methods & $\begin{array}{l}\text { A } 13 \text { month, randomised, double-blind, parallel-group comparison of the efficacy of } \\
\text { Seretide (fluticasone propionate/salmeterol combination Accuhaler) and Flixotide(flu- } \\
\text { ticasone propionate Accuhaler) when down-titrating the inhaled corticosteroid dose in } \\
\text { asthmatic adults who have previously received Seretide } 500 / 50 \text { mcg twice daily for at } \\
\text { least } 4 \text { weeks } \\
\text { A randomized, double-blind, parallel-group study over } 52 \text { weeks from March } 2002 \text { to } \\
\text { February } 2006 \text { at } 3 \text { centres in Australia }\end{array}$ \\
\hline Participants & $\begin{array}{l}\text { Population: } 82 \text { adolescents and adults }(18-80) \text { with asthma. } \\
\text { Baseline Characteristics: Mean age } 47 \text { years. FEV } 1 \text { unknown } \% \text { predicted. Concomitant } \\
\text { inhaled corticosteroids used by } 100 \% \text { of participants. } \\
\text { Inclusion Criteria: Aged between } 18 \text { and } 80 \text { years with a clinical diagnosis of asthma } \\
\text { according to American Thoracic Society criteria for at least } 6 \text { months prior to enrolment, } \\
\text { currently receiving FP/SX, either via dry powder inhaler or metered dose inhaler (with } \\
\text { or without spacer) at a dose of } 500 / 50 \text { mcg bd or } 250 / 25 \text { mc } 2 \text { inhalations bd for a } \\
\text { minimum of } 4 \text { weeks prior to enrolment } \\
\text { Exclusion Criteria: not reported }\end{array}$ \\
\hline
\end{tabular}

Interventions

1. FSC $500 / 50,250 / 50$ or $100 / 50 \mu \mathrm{g}$ BD (Reduced incrementally)

2. FP 500, 250 or $100 \mu \mathrm{g}$ BD (Reduced incrementally)

Delivery was DPI

Outcomes

The primary efficacy endpoint was the average daily FP dose (mcg/day) from week 0 to completion/withdrawal, including study medication and exacerbation medication

Notes

Risk of bias

\begin{tabular}{lll}
\hline Item & Authors' judgement & Description \\
\hline Adequate sequence generation? & Unclear & Not reported \\
\hline Allocation concealment? & Unclear & Not reported \\
\hline $\begin{array}{l}\text { Blinding? } \\
\text { All outcomes }\end{array}$ & Yes & Double blind \\
\hline $\begin{array}{l}\text { Incomplete outcome data addressed? } \\
\text { All outcomes }\end{array}$ & Yes & $60 / 82(73 \%)$ completed the study
\end{tabular}


SAM40031 (Continued)

\begin{tabular}{|c|c|c|}
\hline Free of selective reporting? & Yes & Data on GSK web site \\
\hline
\end{tabular}

\section{SAM40065}

$\begin{array}{ll}\text { Methods } & \text { A randomized, double-blind, double-dummy, multi centre, parallel-group study for } 40 \\ \text { weeks from January } 2003 \text { to October } 2004 \text { at } 44 \text { centres (United States (39), Brazil(3) } \\ \text { Bulgaria(2)). Run-in } 2 \text { weeks } \\ \text { A multicenter, randomized, double-blind, parallel group, 40-week comparison of asthma } \\ \text { control using bronchial hyper responsiveness as an additional guide to long-term } \\ \text { treatment in adolescents and adults receiving either fluticasone propionate/salmeterol } \\ \text { DISKUSTM BID or fluticasone propionate DISKUSTM BID (or placebo BID if asymp- } \\ \text { tomatic) }\end{array}$

$\begin{array}{ll}\text { Participants } & \begin{array}{l}\text { Population: } 449 \text { adults }(12+\text { years) with asthma. } \\ \text { Baseline Characteristics: Mean age } 34 \text { years. FEV }\end{array} \text { not reported \% predicted. Con- } \\ \text { comitant inhaled corticosteroids used by } 100 \% \text { of participants. } \\ \text { Inclusion Criteria: } 12 \text { years of age or older, with a diagnosis of asthma, as defined by } \\ \text { the American Thoracic Society (ATS), for at least three months prior to visit } 1 \text { and must } \\ \text { have been treated with a short-acting beta } 2 \text {-agonist, an anticholinergic, or an allowed } \\ \text { ICS at a fixed dosing regimen (within an allowed total daily dose) for at least four weeks } \\ \text { prior to the screening visit. FEV } 1 \% \text { predicted between } 60 \% \text { to } 95 \% \text {, bronchodilator } \\ \text { reversibility by an increase of at least } 12 \% \text { in FEV } \mathrm{F}_{1} \text { over baseline within } 30 \text { minutes } \\ \text { following } 2 \text { puffs of albuterol inhalation aerosol at the screening visit. Documentation } \\ \text { of historical reversibility within } 24 \text { months was allowed. } \\ \text { Exclusion Criteria: history of life-threatening asthma, current unstable asthma, current } \\ \text { respiratory tract infection or clinically significant concurrent disease that would put the } \\ \text { subject at risk during the study if the condition exacerbated }\end{array}$

Interventions
$\begin{aligned} & \text { 1. FSC } 100 / 50,250 / 50 \text { or } 500 / 50 \mu \mathrm{g} \mathrm{BD} \\ & \text { 2. FP } 100,250 \text { or } 500 \mu \mathrm{g} \text { BD (BHR strategy) } \\ & \text { 3. FP } 100,250 \text { or } 500 \mu \mathrm{g} \text { BD (Reference strategy) } \\ & \text { Delivery was Diskus device (third arm not used in this review) }\end{aligned}$

Outcomes

The primary efficacy endpoint was the average inhaled corticosteroid treatment dose over the treatment period

Notes SAE data included run-in

\section{Risk of bias}

\begin{tabular}{lll}
\hline Item & Authors' judgement & Description \\
\hline Adequate sequence generation? & Unclear & Not reported \\
\hline Allocation concealment? & Unclear & Not reported \\
\hline $\begin{array}{l}\text { Blinding? } \\
\text { All outcomes }\end{array}$ & Yes & Double blind \\
\hline
\end{tabular}

Regular treatment with salmeterol and inhaled steroids for chronic asthma: serious adverse events (Review)

Copyright (C) 2009 The Cochrane Collaboration. Published by John Wiley \& Sons, Ltd. 
SAM40065 (Continued)

\begin{tabular}{l|l|l}
\hline $\begin{array}{l}\text { Incomplete outcome data addressed? } \\
\text { All outcomes }\end{array}$ & Yes & $322 / 449(72 \%)$ completed the study \\
\hline Free of selective reporting? & Yes & Data on GSK web site \\
\hline
\end{tabular}

\section{SAS30021}

$\begin{array}{ll}\text { Methods } & \text { A stratified, randomized, double-blind, placebo-controlled, parallel-group study for } 12 \\ \text { weeks from November } 2001 \text { to February } 2004 \text { at } 164 \text { centres (United States (153), Latin } \\ \text { America(11)) } \\ \text { A Stratified, Randomized, Double-Blind, Placebo-Controlled, Parallel-Group, 12-Week } \\ \text { Trial Evaluating the Safety and Efficacy of the Fluticasone Propionate/Salmeterol } \\ \text { DISKUS Combination Product 100/50mcg Once Daily Versus Fluticasone Propionate } \\ \text { DISKUS 100mcg Once Daily and Placebo in Symptomatic Pediatric Subjects (4-11 } \\ \text { Years) With Asthma }\end{array}$

Participants
Baseline Characteristics: Mean age 8 years. $\mathrm{FEV}_{1}$ not reported \% predicted. Concomi-
tant inhaled corticosteroids used by $0 \%$ of participants.
Inclusion Criteria: $4-11 \mathrm{yrs}$ of age with a diagnosis of asthma for at least 6 months and
treated with short-acting beta2-agonists only or non-ICS controller medications for at
least one month prior to Screening. FEV $\%$ predicted between $50 \%$ to $85 \%$, bron-
chodilator reversibility by an increase of at least $15 \%$ in FEV $\mathrm{F}_{1}$ over baseline within 30
minutes following 2 puffs of albuterol at screening. At the Randomisation Visit, subjects
were required to demonstrate AM PEF reproducibility of +15\% of the Screening Visit
pre-albuterol PEF, demonstrate a PM PEF $50-90 \%$ of predicted normal, and have either
an asthma symptom score of at least 2 on 4 or more days in the week prior to randomi-
sation, or have used albuterol on at least 4 days in the week prior to randomisation
Exclusion Criteria: Not reported

\begin{tabular}{l|l}
\hline Interventions & 1. FSC $100 / 50 \mu \mathrm{g}$ QD \\
2. FP $100 \mu \mathrm{g}$ QD \\
Delivery was Diskus device
\end{tabular}

Outcomes

The primary efficacy endpoint was the change from Baseline in \% predicted PM Peak Expiratory Flow (PEF) over Weeks 1-12

\begin{tabular}{lll}
\hline Notes & Once daily dose & \\
\hline Risk of bias & & \\
\hline Item & Authors' judgement & Description \\
\hline Adequate sequence generation? & Unclear & Not reported \\
\hline Allocation concealment? & Unclear & Not reported
\end{tabular}


SAS30021 (Continued)

\begin{tabular}{lll}
\hline $\begin{array}{l}\text { Blinding? } \\
\text { All outcomes }\end{array}$ & Yes & Double blind \\
\hline $\begin{array}{l}\text { Incomplete outcome data addressed? } \\
\text { All outcomes }\end{array}$ & Yes & $715 / 908(79 \%)$ completed the study \\
\hline Free of selective reporting? & Yes & Data on GSK web site \\
\hline
\end{tabular}

SAS30022

$\begin{array}{ll}\text { Methods } & \text { A randomized, double-blind, placebo-controlled, parallel-group study for } 12 \text { weeks from } \\ \text { November } 2001 \text { to June } 2003 \text { at } 121 \text { centres. (US (103), Canada (18)) } \\ \text { A randomized, double-blind, placebo-controlled, parallel-group, 12-week trial evaluat- } \\ \text { ing the efficacy and safety of the fluticasone propionate/salmeterol DISKUS combina- } \\ \text { tion product } 250 / 50 \mathrm{mcg} \text { once daily versus fluticasone propionate/salmeterol DISKUS } \\ \text { combination product } 100 / 50 \mathrm{mcg} \text { twice daily versus fluticasone propionate DISKUS } \\ \text { 250mcg once daily versus placebo in symptomatic adolescent and adult subjects with } \\ \text { asthma that is not controlled on short acting beta2-agonists alone }\end{array}$

Participants

Population: 844 adolescents and adults $(12+$ years $)$ with asthma that was not controlled on short-acting beta2-agonists alone

Baseline Characteristics: Mean age 33 years. $\mathrm{FEV}_{1}$ not reported \% predicted. Concomitant inhaled corticosteroids used by zero $\%$ of participants

Inclusion Criteria: 12 years of age or older with a diagnosis of asthma for at least 3 months and treated with short-acting beta2-agonists only for at least one month prior to screening. $\mathrm{FEV}_{1} \%$ predicted between $50 \%$ to $85 \%$, bronchodilator reversibility by an increase of at least $15 \%$ in $\mathrm{FEV}_{1}$ over baseline within 30 minutes following 2 puffs of albuterol at screening

At the Randomization Visit, subjects were required to demonstrate FEV1 reproducibility of $\pm 15 \%$ of the Screening Visit pre-VENTOLIN FEV1, demonstrate a PM PEF 50$90 \%$ of predicted normal, and have either an asthma symptom score of at least 2 on 4 or more days in the week prior to randomization, or have used VENTOLIN on at least 4 days in the week prior to randomization.

Exclusion Criteria: not reported

\begin{tabular}{l|l}
\hline Interventions & 1. FSC $250 / 50 \mu \mathrm{g}$ QD \\
2. FSC $100 / 50 \mu \mathrm{g}$ BD \\
3. FP $250 \mu \mathrm{g}$ QD \\
(Second arm not used in this review)
\end{tabular}

Outcomes

Primary Outcome/Efficacy Variable was the change from Baseline in \% predicted PM peak expiratory flow (PEF) over Weeks 1-12

Notes

Risk of bias

Item

Authors' judgement

Description

Regular treatment with salmeterol and inhaled steroids for chronic asthma: serious adverse events (Review)

Copyright (C) 2009 The Cochrane Collaboration. Published by John Wiley \& Sons, Ltd. 
SAS30022

(Continued)

\begin{tabular}{l|l|l}
\hline Adequate sequence generation? & Unclear & Not reported \\
\hline Allocation concealment? & Unclear & Not reported \\
\hline $\begin{array}{l}\text { Blinding? } \\
\text { All outcomes }\end{array}$ & Yes & Double blind \\
\hline $\begin{array}{l}\text { Incomplete outcome data addressed? } \\
\text { All outcomes }\end{array}$ & Unclear & $698 / 844(83 \%)$ completed the study \\
\hline \begin{tabular}{l} 
Free of selective reporting? \\
\hline
\end{tabular} & Yes & Data on GSK web site \\
\hline
\end{tabular}

\section{SAS30023}

Methods

A randomized, double-blind, multi centre, placebo-controlled, parallel-group study over 12 weeks from April 2002 to April 2003 at 69 centres in 9 countries (Australia, France, UK, Hungary, Ukraine, Italy, Philippines, Thailand, Russia)

A 12-week multi centre, randomised, double-blind, placebo-controlled parallel group study to compare the efficacy and tolerability of fluticasone propionate/salmeterol combination (SERETIDE/VIANI/ADVAIR) $88 / 42 \mathrm{mcg}$ once daily in the morning with fluticasone propionate $88 \mathrm{mcg}$ once daily in the morning and placebo (short-acting B2agonist as required only) once daily in the morning, all via the HFA MDI as initial maintenance therapy in mild asthmatic subjects

Participants

Population: 464 adolescents and adults $(12-80)$ with mild asthma.

Baseline Characteristics: Mean age 34 years. FEV 1 not reported \% predicted. Concomitant inhaled corticosteroids used by zero $\%$ of participants.

Inclusion Criteria: a documented clinical history of asthma for at least 6 months who were currently receiving short-acting ß2-agonists alone

Exclusion Criteria: Not reported.

\begin{tabular}{l|l}
\hline Interventions & $\begin{array}{l}\text { 1. FSC } 44 / 21 \mu \mathrm{g} \text { two puffs once daily } \\
\text { 2. FP } 44, \mu \mathrm{g} \text { two puffs once daily } \\
\text { Delivery was MDI device with HFA propellant }\end{array}$
\end{tabular}

Outcomes

The primary efficacy endpoint was the morning PEF

Notes

Risk of bias

\begin{tabular}{lll}
\hline Item & Authors' judgement & Description \\
\hline Adequate sequence generation? & Unclear & Not reported \\
\hline Allocation concealment? & Unclear & Not reported
\end{tabular}


SAS30023

\begin{tabular}{l|l|l}
\hline $\begin{array}{l}\text { Blinding? } \\
\text { All outcomes }\end{array}$ & Yes & Double blind \\
\hline $\begin{array}{l}\text { Incomplete outcome data addressed? } \\
\text { All outcomes }\end{array}$ & Yes & $433 / 464$ (93\%) completed the study \\
\hline \begin{tabular}{l} 
Free of selective reporting? \\
\hline
\end{tabular} & Yes & Data on GSK web site \\
\hline
\end{tabular}

\section{SAS40036}

\begin{tabular}{|c|c|c|}
\hline Methods & \multicolumn{2}{|c|}{$\begin{array}{l}\text { A randomized, double-blind, double-dummy, multicenter, parallel-group study for } 10 \\
\text { weeks from October } 2001 \text { to May } 2003 \text { at } 85 \text { centres in the United States. Run-in twc } \\
\text { weeks }\end{array}$} \\
\hline Participants & \multicolumn{2}{|c|}{$\begin{array}{l}\text { Population: } 331 \text { adolescents and adults }(15+\text { years old) with persistent asthma } \\
\text { Baseline Characteristics: Mean age } 41 \text { years. } \mathrm{FEV}_{1} \text { not reported (\% predicted). Con- } \\
\text { comitant inhaled corticosteroids used by } 100 \% \text { of participants. } \\
\text { Inclusion Criteria: } 15 \text { years of age or older, with a diagnosis of asthma, as defined by the } \\
\text { American Thoracic Society (ATS), for at least six months prior to visit } 1 \text { and must have } \\
\text { been treated with an allowed ICS at a fixed dosing regimen (within an allowed total daily } \\
\text { dose) for at least four weeks prior to the screening visit. } \mathrm{FEV}_{1} \% \text { predicted between } 40 \% \\
\text { to } 85 \% \text {, bronchodilator reversibility by an increase of at least } 12 \% \text { in FEV } \mathrm{F}_{1} \text { over baseline } \\
\text { within } 30 \text { minutes following } 2-4 \text { puffs of albuterol inhalation aerosol at the screening } \\
\text { visit. Documentation of historical reversibility within } 24 \text { months was allowed. } \\
\text { Exclusion Criteria: Not reported }\end{array}$} \\
\hline Interventions & \multicolumn{2}{|c|}{$\begin{array}{l}\text { 1. FSC } 100 / 50 \mu \mathrm{g} \text { BD } \\
\text { 2. FP } 100 \mu \mathrm{g} \text { BD } \\
\text { Delivery was Diskus device (other arms of trial not considered for this review) }\end{array}$} \\
\hline Outcomes & \multicolumn{2}{|c|}{$\begin{array}{l}\text { The primary efficacy endpoint was the mean change from baseline at endpoint in morn- } \\
\text { ing peak expiratory flow (PEF) }\end{array}$} \\
\hline Notes & \multicolumn{2}{|c|}{ No SAEs at all reported in double blind phase of the study. } \\
\hline \multicolumn{3}{|l|}{ Risk of bias } \\
\hline Item & Authors' judgement & Description \\
\hline Adequate sequence generation? & Unclear & Not reported \\
\hline Allocation concealment? & Unclear & Not reported \\
\hline $\begin{array}{l}\text { Blinding? } \\
\text { All outcomes }\end{array}$ & Yes & Double blind, double dummy \\
\hline $\begin{array}{l}\text { Incomplete outcome data addressed? } \\
\text { All outcomes }\end{array}$ & Yes & $243 / 331(73 \%)$ completed the study \\
\hline
\end{tabular}


SAS40036 (Continued)

\begin{tabular}{|c|c|c|}
\hline Free of selective reporting? & Yes & Data on GSK web site \\
\hline
\end{tabular}

\section{SAS40037}

\begin{tabular}{ll} 
Methods & $\begin{array}{l}\text { A randomized, double-blind, double-dummy, multicenter, parallel-group study for } 16 \\
\text { weeks from October } 2001 \text { to May } 2003 \text { at } 87 \text { centres in the United States. Run-in two } \\
\text { weeks }\end{array}$ \\
\hline Participants & $\begin{array}{l}\text { Population: } 331 \text { adolescents and adults }(15+\text { years old) with persistent asthma } \\
\text { Baseline Characteristics: Mean age } 41 \text { years. FEV } 1 \text { not reported (\% predicted). Con- } \\
\text { comitant inhaled corticosteroids used by } 100 \% \text { of participants. } \\
\text { Inclusion Criteria: } 15 \text { years of age or older, with a diagnosis of asthma, as defined by the } \\
\text { American Thoracic Society (ATS), for at least six months prior to visit } 1 \text { and must have } \\
\text { been treated with an allowed ICS at a fixed dosing regimen (within an allowed total daily } \\
\text { dose) for at least four weeks prior to the screening visit. FEV } \% \text { predicted between } 40 \% \\
\text { to } 85 \%, \text { bronchodilator reversibility by an increase of at least } 12 \% \text { in FEV } V_{1} \text { over baseline } \\
\text { within } 30 \text { minutes following } 2-4 \text { puffs of albuterol inhalation aerosol at the screening } \\
\text { visit. Documentation of historical reversibility within } 24 \text { months was allowed. } \\
\text { Exclusion Criteria: diagnosed with life-threatening asthma, hospitalised for asthma } \\
\text { within the previous } 6 \text { months, had a concurrent respiratory disease, or had intermittent } \\
\text { or seasonal asthma alone, had a respiratory tract infection or used antibiotics for the } \\
\text { treatment of a suspected or diagnosed respiratory tract infection within } 14 \text { days of Visit } \\
1\end{array}$ \\
\hline
\end{tabular}

\begin{tabular}{|c|c|}
\hline Interventions & $\begin{array}{l}\text { 1. FSC } 100 / 50 \mu \mathrm{g} \mathrm{BD} \\
\text { 2. FP } 100 \mu \mathrm{g} \text { BD } \\
\text { Delivery was Diskus device (other arms of trial not considered for this review) }\end{array}$ \\
\hline
\end{tabular}

Outcomes

The primary efficacy endpoint was the mean change from baseline at endpoint in morning peak expiratory flow (PEF)

Notes

Risk of bias

\begin{tabular}{l|ll}
\hline Item & Authors' judgement & Description \\
\hline Adequate sequence generation? & Unclear & Not reported \\
\hline Allocation concealment? & Unclear & Not reported \\
\hline $\begin{array}{l}\text { Blinding? } \\
\text { All outcomes }\end{array}$ & Yes & double blind, double dummy \\
\hline $\begin{array}{l}\text { Incomplete outcome data addressed? } \\
\text { All outcomes }\end{array}$ & Yes & 230/322 (71\%) completed the study
\end{tabular}


SAS40037 (Continued)

\begin{tabular}{|c|c|c|}
\hline Free of selective reporting? & Yes & Data on GSK web site \\
\hline
\end{tabular}

\section{SAS40068}

\begin{tabular}{|c|c|}
\hline Methods & $\begin{array}{l}\text { A randomized, double-blind, multicenter, parallel-group study for } 24 \text { weeks from Oc- } \\
\text { tober } 2002 \text { to February } 2004 \text { at } 58 \text { centres in Canada } \\
\text { A } 24 \text { week, multi centre, randomized, double-blind, parallel group trial to compare } \\
\text { the efficacy and tolerability of salmeterol/fluticasone propionate (ADVAIR) DISKUS } \\
\text { inhalation device } 50 / 100 \mathrm{mcg} \text { bid with fluticasone propionate DISKUS inhalation device } \\
100 \text { mcg bid as initial maintenance treatment in adult and adolescent subjects with } \\
\text { symptomatic, persistent asthma not controlled on short-acting bronchodilators alone }\end{array}$ \\
\hline
\end{tabular}

Participants

Population: 532 adolescents and adults(12+ years ) with symptomatic, persistent asthma. Baseline Characteristics: Mean age 35 years. $\mathrm{FEV}_{1}$ not reported \% predicted. Concomitant inhaled corticosteroids used by $0 \%$ of participants.

Inclusion Criteria: 12 years of age or older with symptomatic, persistent mild asthma (defined as $\mathrm{FEV}_{1}$ at least $80 \%$ predicted and over the last 7 consecutive days of run-in, had an asthma symptom score of 2 , or more on at least 3 days or disruptions of normal sleep patterns on 2 or more occasions, or had used rescue bronchodilator medication on 4 or more days), and treated with inhaled short-acting bronchodilators alone

Exclusion Criteria: taken any other asthma therapy (e.g. inhaled corticosteroids, leukotriene modifiers, inhaled long-acting beta2-agonists) within 1 month prior to screening, had a smoking history of 10 pack years or more, or had an acute asthma exacerbation requiring emergency room treatment within the last 6 weeks or hospitalization within the last 12 weeks prior to screening

\begin{tabular}{l|l} 
Interventions & 1. FSC $100 / 50 \mu \mathrm{g} \mathrm{BD}$ \\
2. FP $100 \mu \mathrm{g}$ BD \\
Delivery was Diskus device
\end{tabular}

Outcomes

The primary efficacy endpoint was the change from baseline in daily record card (DRC) mean morning peak expiratory flow (PEF) over 24 weeks

One death due to aorta hypoplasia and ventricular hypertrophy on Fluticasone

Notes

Risk of bias

\begin{tabular}{lll}
\hline Item & Authors' judgement & Description \\
\hline Adequate sequence generation? & Unclear & Not reported \\
\hline Allocation concealment? & Unclear & Not reported \\
\hline $\begin{array}{l}\text { Blinding? } \\
\text { All outcomes }\end{array}$ & Yes & Double blind
\end{tabular}




\begin{tabular}{l|l|l}
$\begin{array}{l}\text { Incomplete outcome data addressed? } \\
\text { All outcomes }\end{array}$ & Yes & $433 / 532(81 \%)$ completed the study \\
\hline Free of selective reporting? & Yes & Data in GSK web site \\
\hline
\end{tabular}

\section{SFA103153}

\begin{tabular}{|c|c|c|}
\hline Methods & \multicolumn{2}{|c|}{$\begin{array}{l}\text { A randomized, double-blind,multicenter, parallel-group study for } 52 \text { weeks from } \\
\text { November } 2004 \text { to April } 2007 \text { at } 59 \text { centres in the United States. Run-in } 4 \text { weeks }\end{array}$} \\
\hline Participants & \multicolumn{2}{|c|}{$\begin{array}{l}\text { Population: } 475 \text { adolescents and adults }(12-65) \text { of African descent with persisten } \\
\text { asthma } \\
\text { Baseline Characteristics: Mean age } 32 \text { years. } \mathrm{FEV}_{1} 78 \% \text { predicted. Concomitant in } \\
\text { haled corticosteroids used by } 100 \% \text { of participants. } \\
\text { Inclusion Criteria: Subjects were of African descent, } 12 \text { to } 65 \text { years of age with persisten } \\
\text { asthma, and were symptomatic while taking an ICS } \\
\text { Exclusion Criteria: Not reported }\end{array}$} \\
\hline Interventions & \multicolumn{2}{|c|}{$\begin{array}{l}\text { 1. FSC } 100 / 50 \mu \mathrm{g} \text { BD } \\
\text { 2. FP } 100 \mu \mathrm{g} \text { BD } \\
\text { Delivery was Diskus device }\end{array}$} \\
\hline Outcomes & \multicolumn{2}{|c|}{ The primary efficacy endpoint was asthma exacerbation rate per subject per year } \\
\hline \multicolumn{3}{|l|}{ Notes } \\
\hline \multicolumn{3}{|l|}{ Risk of bias } \\
\hline Item & Authors' judgement & Description \\
\hline Adequate sequence generation? & Unclear & Not reported \\
\hline Allocation concealment? & Unclear & Not reported \\
\hline $\begin{array}{l}\text { Blinding? } \\
\text { All outcomes }\end{array}$ & Yes & Double blind \\
\hline $\begin{array}{l}\text { Incomplete outcome data addressed? } \\
\text { All outcomes }\end{array}$ & Yes & $320 / 475(67 \%)$ completed the study \\
\hline Free of selective reporting? & Yes & Data on GSK web site \\
\hline
\end{tabular}




A randomized, double-blind, multicenter, parallel-group study for 24 weeks from May
2002 to November 2003 at 124 centres in France. Run-in 8 weeks
Maintenance of asthma control in adults: comparison of three therapeutic strategies in
patients whose asthma is controlled by a medium dose of inhaled corticosteroid and a
long-acting inhaled beta2-agonist

Participants
Baseline Characteristics: Mean age 45 years. FEV 1 not reported \% predicted. Con-
comitant inhaled corticosteroids used by $100 \%$ of participants
Inclusion Criteria: 18 years of age or older with a documented history of asthma (for
at least 6 months) and whose asthma was controlled with the current treatment (inhaled
corticosteroid at a dose of $1000 \mathrm{mcg}$ of CFC beclomethasone dipropionate or equivalent
and a long-acting beta2-agonist at recommended dose) at stable dose for at least 4 weeks
prior to the run-in period. Randomized if fulfilled the following criteria: at least 2 of
the following: diurnal symptoms at least 2 days per week, use of rescue short-acting
bronchodilator no more than 2 days per week and no more than 4 occasions per week,
PEF at least $80 \%$ predicted every day. Plus all the following criteria: no night-time
awakenings due to asthma, no exacerbations, no emergency visits, no treatment related
adverse events enforcing a change in asthma therapy.
Exclusion Criteria: for entry in the run in period:smoking history of ten pack-years
or more, respiratory tract infection during the last 4 weeks prior to visit 1 (the last
2 weeks after amendment number 1 ), acute asthma exacerbation requiring emergency
room treatment or hospitalization within 4 weeks prior to visit 1 , use of oral/parenteral
corticosteroids during the last 4 weeks prior to visit 1 or any change in maintenance
treatment, use of depot corticosteroid within 12 weeks of visit 1. For entry into the
treatment period: changes in asthma medication (excluding study rescue medication), use
of oral/parenteral or depot corticosteroids, respiratory tract infection, insufficient asthma
control, according to daily record card, asthma control questionnaire and investigator's
judgement to allow a reduction in maintenance treatment

Notes

Risk of bias

\begin{tabular}{lll}
\hline Item & Authors' judgement & Description \\
\hline Adequate sequence generation? & Unclear & Not reported \\
\hline Allocation concealment? & Unclear & Not reported
\end{tabular}


SFCF4026 (Continued)

\begin{tabular}{l|l|l}
\hline $\begin{array}{l}\text { Blinding? } \\
\text { All outcomes }\end{array}$ & Yes & Double blind \\
\hline $\begin{array}{l}\text { Incomplete outcome data addressed? } \\
\text { All outcomes }\end{array}$ & Yes & $413 / 476(87 \%)$ completed the study \\
\hline Free of selective reporting? & Yes & Data on GSK web site \\
\hline
\end{tabular}

Shapiro 2000

\begin{tabular}{|c|c|c|}
\hline Methods & \multicolumn{2}{|c|}{ Setting: multi centre study, USA } \\
\hline Participants & \multicolumn{2}{|c|}{$\begin{array}{l}349 \text { adults and adolescents randomised (four treatment arm study; FPS: } 84 \text {; FP: } 84 \\
\text { Data from } 13 \text { participants excluded from the analysis due to poor procedure at one site) } \\
\text { Inclusion criteria: }>/=12 \text { years; ATS defined asthma of }>/=6 \text { mo duration requiring } \\
\text { pharmacotherapy for at least } 6 \text { months; FEV1 between } 40 \text { and } 85 \% \text { predicted; }>/=15 \% \\
\text { increase in FEV1 } 30 \text { mins after } 2 \text { puffs of albuterol; use of ICS } 12 \text { weeks prior to the } \\
\text { study } \\
\text { Exclusion criteria: Females with negative pregnancy tests; life-threatening asthma; hyper- } \\
\text { sensitivity to sympathomimetic drugs/steroids; smoking within previous year; smoking } \\
\text { history of }>10 \text { pack years; use of oral/injectable steroid therapy within } 1 \text { month of study } \\
\text { use of daily oral steroids within } 6 \text { months prior to the study; use of any prescription or } \\
\text { over the counter medication that could have affected asthma or course of treatment; ab- } \\
\text { normal CXR; clinically significant abnormal } 12 \text {-lead ECGs history of concurrent disease }\end{array}$} \\
\hline Interventions & \multicolumn{2}{|c|}{$\begin{array}{l}\text { 1. FSC } 250 / 50 \text { bd } \\
\text { 2. Fluticasone } 250 \text { bd } \\
\text { Third arm not used in this review }\end{array}$} \\
\hline Outcomes & \multicolumn{2}{|c|}{$\begin{array}{l}83 \% \text { completed study in FPS arm and } 73 \% \text { in FP arm. } \\
\text { Paper reports "no serious drug-related adverse events. Two patients treated with salme- } \\
\text { terol withdrew from the study because of adverse events; however, these adverse events } \\
\text { were considered by the investigator to be unrelated to study drug (bilateral subcapsular } \\
\text { cataracts and postsurgical infection)." } \\
\text { Website SFCA3003: no fatal adverse events. No serious adverse events in FPS arm; one } \\
\text { in FP arm (Asthma exacerbation) }\end{array}$} \\
\hline \multicolumn{3}{|l|}{ Notes } \\
\hline \multicolumn{3}{|l|}{ Risk of bias } \\
\hline Item & Authors' judgement & Description \\
\hline Adequate sequence generation? & Unclear & Not stated \\
\hline Allocation concealment? & Unclear & Not stated \\
\hline
\end{tabular}




\begin{tabular}{l|ll}
\hline $\begin{array}{l}\text { Blinding? } \\
\text { All outcomes }\end{array}$ & Yes & Double blind \\
\hline $\begin{array}{l}\text { Incomplete outcome data addressed? } \\
\text { All outcomes }\end{array}$ & Yes & $131 / 168(78 \%)$ completed the study \\
\hline Free of selective reporting? & Yes & Full data on GSK web site \\
\hline
\end{tabular}

SLGF75

$\begin{array}{ll}\text { Methods } & \text { A randomized, double-blind, multicenter, parallel-group study for } 12 \text { weeks from January } \\ 1998 \text { to December } 1998 \text { at } 7 \text { centres in Italy. Run-in } 4 \text { weeks, follow-up } 2 \text { weeks } \\ \text { Salmeterol plus low-dose fluticasone propionate (FP) versus high-dose fluticasone pro- } \\ \text { pionate (FP) in naive patients with mild to moderate asthma: effects on pulmonary } \\ \text { function, and inflammatory markers of induced sputum }\end{array}$

\begin{tabular}{|c|c|}
\hline Participants & $\begin{array}{l}\text { Population: } 46 \text { adolescents and adults }(16-65) \text { with mild to moderate asthma } \\
\text { Baseline Characteristics: Mean age } 39 \text { years. } \mathrm{FEV}_{1} \text { unreported } \% \text { predicted. Concomi- } \\
\text { tant inhaled corticosteroids used by } 0 \% \text { of participants. } \\
\text { Inclusion Criteria: performed on three study visits. } \\
\text { Pre-study visit: all subjects with asthma disease for at least } 6 \text { months, } \\
\text { Visit 2: } 16-65 \text { years old with asthma at moderate level (score of severity at least } 6 \text { ), did } \\
\text { not use anti-inflammatory drugs for last month before visit } 1, \mathrm{FEV}_{1} \% \text { predicted at least } \\
60 \% \text {, eosinophils at least } 5 \% \text { in induced sputum. } \\
\text { Visit } 4 \text { : bronchial asthma assessed up to } 6 \text { (severity classes value) and with persistence of } \\
\text { eosinophils at least } 5 \% \text { (or at least } 3 \% \text { in sites where an amendment was applicable) in } \\
\text { induced sputum } \\
\text { Exclusion Criteria: inhaled steroids or cromones in last } 3 \text { months, more than one short } \\
\text { course of oral steroids in last } 3 \text { months or one short course of oral steroids in last month } \\
\text { before pre-study visit; respiratory tract infection in the last } 1 \text { month pre-study visit, with } \\
\text { lung or other important disease, or on Beta-blocker therapy; hypersensitivity to Beta 2- } \\
\text { agonist and suspected to abuse drug or alcohol }\end{array}$ \\
\hline
\end{tabular}

\begin{tabular}{l|l}
\hline Interventions & 1. FP $100+\mathrm{SAL} 50 \mu \mathrm{g}$ BD \\
2. FP $100 \mu \mathrm{g} \mathrm{BD}$ \\
3. FP $250 \mu \mathrm{gBD}$ \\
Delivery was Diskus (third arm not used in this review) \\
\hline
\end{tabular}

Notes

Risk of bias

\begin{tabular}{lll}
\hline Item & Authors' judgement & Description \\
\hline Adequate sequence generation? & Unclear & Not reported
\end{tabular}


SLGF75

\begin{tabular}{lll}
\hline Allocation concealment? & Unclear & Not reported \\
\hline $\begin{array}{l}\text { Blinding? } \\
\text { All outcomes }\end{array}$ & Yes & Double blind \\
\hline $\begin{array}{l}\text { Incomplete outcome data addressed? } \\
\text { All outcomes }\end{array}$ & Yes & $42 / 46(91 \%)$ completed the study \\
\hline \begin{tabular}{l} 
Free of selective reporting? \\
\hline
\end{tabular}
\end{tabular}

\section{Strand 2004}

\section{Methods}

Participants
A randomized, double-blind, comparative, multicenter, parallel-group study over 12 weeks from May 2001 to September 2002 at 45 centres in Denmark. Run-in 2 weeks

Population: 150 adults with persistent asthma

Baseline Characteristics: Mean age 39 years. PEF $80 \%$ predicted. Concomitant inhaled corticosteroids used by $0 \%$ of participants.

Inclusion Criteria:At least 18 years old and an asthma medical history of at least 3 months, either diurnal PEF variation $220 \%$ on at least 2 days or one of the following must have been determined within 3 years prior to baseline: forced expiratory volume in 1 second $\left(\mathrm{FEV}_{1}\right)$ reversibility ? $15 \%$ in response to bronchodilator, provocative concentration of methacholine causing a $20 \%$ fall in $\mathrm{FEV}_{1}\left(\mathrm{PC}_{20}\right)$ less than $4 \mathrm{mg} / \mathrm{mL}$, diurnal PEF variation at least 20\%; mean relief medication (albuterol) use at least 1 episode/ week; and day or night symptom score 1 or more at least once/week.

Exclusion Criteria: Upper or lower respiratory tract infection or middle ear infection within 1 month prior to visit 1 ; other lung diseases than asthma; known or suspected other diseases or situations likely to affect the outcome of the study results; known serious cardiovascular disease, diabetes mellitus, untreated hypokalaemia, or thyrotoxicosis; use of long-acting bronchodilators, inhaled corticosteroids, or other long-acting asthma medication within 2 months prior to visit 1; use of daily oral corticosteroid treatment within 2 months of visit 1 or oral corticosteroid therapy within 1 month prior to visit

1. FSC $100 / 50 \mu \mathrm{g} B D$

2. FP $100 \mu \mathrm{g} B D$

The primary efficacy variable was symptom-free days and nights

"1 patient in the S/FP group and 2 patients in the FP group had a serious adverse event.

None of these serious adverse events was considered related to the study drug."

One death reported on the web site in the FP arm but no cause given

Notes

Risk of bias

\begin{tabular}{lll}
\hline Item & Authors' judgement & Description \\
\hline Adequate sequence generation? & Unclear & Not reported \\
\hline
\end{tabular}


Strand 2004 (Continued)

\begin{tabular}{l|ll}
\hline Allocation concealment? & Unclear & Not reported \\
\hline $\begin{array}{l}\text { Blinding? } \\
\text { All outcomes }\end{array}$ & Yes & Double blind \\
\hline $\begin{array}{l}\text { Incomplete outcome data addressed? } \\
\text { All outcomes }\end{array}$ & Yes & $126 / 150$ completed study \\
\hline \begin{tabular}{l} 
Free of selective reporting? \\
\hline
\end{tabular}
\end{tabular}

van Noord 2001

Methods

A randomized, double-blind, double-dummy, multicenter, placebo-controlled, parallelgroup study over 3 months from December 1997 to March 1999 at 61 centres in 13 countries. Run in 2 weeks

Participants
Population: 509 adolescents and adults $(12-82)$ years with moderate to severe asthma
Baseline Characteristics: Mean age 47 years. $\mathrm{FEV}_{1} 72 \%$ predicted. Concomitant in-
haled corticosteroids used by $100 \%$ of participants
Inclusion Criteria: 12 years old or more with a documented clinical history of reversible
airways obstruction and symptomatic on ICS therapy (beclomethasone dipropionate,
budesonide or flunisolide at a dose of $1500-2000 \mu \mathrm{g} /$ day or FP 750 to $1000 \mu \mathrm{\mu g}$ day) for at
least four weeks before the start of the study. FEV $1 \%$ predicted between $50 \%$ to $100 \%$.
During the last seven days of the run-in period, required to have had a mean morning
PEFR of $>50 \%$ and $<85 \%$ of PEFR measured 15 minutes after administration of $400 \mu \mathrm{g}$
of salbutamol at the randomisation visit, and a cumulative total symptom score (daytime
plus night-time) in the daily record card of at least 8.

\begin{tabular}{|l|l|}
\hline Interventions & 1. FSC $500 / 50 \mu \mathrm{g}$ HFA BD via MDI \\
2. FSC $500 / 50 \mu \mathrm{g}$ HFA BD via Diskus \\
3. FP $500 \mu \mathrm{g}$ CFC BD via MDI
\end{tabular}

Outcomes

Primary efficacy variable was the mean morning PEF over the 12-week treatment period Paper reports eight patients with SAE in FPS groups and 2 on FP. These included 3 asthma exacerbations. Web report indicates that 2 of these were on FPS and one on FP One death report on FSC via MDI due to Leukaemia

\section{Notes}

Risk of bias

\begin{tabular}{l|ll}
\hline Item & Authors' judgement & Description \\
\hline Adequate sequence generation? & Unclear & Not stated \\
\hline $\begin{array}{l}\text { Regular treatment with salmeterol and inhaled steroids for chronic asthma: serious adverse events (Review) } \\
\text { Copyright } \odot 2009 \text { The Cochrane Collaboration. Published by John Wiley \& Sons, Ltd. }\end{array}$ & $\mathbf{7 0}$
\end{tabular}


van Noord 2001 (Continued)

\begin{tabular}{l|ll}
\hline Allocation concealment? & Unclear & Not stated \\
\hline $\begin{array}{l}\text { Blinding? } \\
\text { All outcomes }\end{array}$ & Yes & Double-blind, double-dummy \\
\hline $\begin{array}{l}\text { Incomplete outcome data addressed? } \\
\text { All outcomes }\end{array}$ & Yes & $447 / 509(88 \%)$ completed the study \\
\hline \begin{tabular}{l} 
Free of selective reporting? \\
\hline
\end{tabular} & Yes & Full data on GSK website \\
\hline
\end{tabular}

Wallin 2003

\begin{tabular}{|c|c|c|}
\hline Methods & \multicolumn{2}{|c|}{ A randomized, double-blind, parallel-group study over 12 weeks. Run-in 2 to 4 weeks } \\
\hline Participants & \multicolumn{2}{|c|}{$\begin{array}{l}\text { Population: } 56 \text { asthmatics, previously not well-controlled on inhaled corticosteroids } \\
\text { Baseline Characteristics: Mean age } 42 \text { years. } \mathrm{FEV}_{1} 88 \% \text { predicted. } \\
\text { Concomitant inhaled corticosteroids used by } 100 \% \text { of participants. } \\
\text { Inclusion Criteria:asthma symptoms on six or more days or four or more nights; need for } \\
\text { rescue salbutamol on six or more days or four or more nights; greater than } 20 \% \text { variation } \\
\text { between AM and PM PEF on four or more days; pulmonary function, one or more of: } \\
\text { at least } 15 \% \text { increase in FEV } 15 \text { mins after inhalation of } 400-800 \mu g \text { salbutamol, at } \\
\text { least } 15 \% \text { increase in PEF } 15 \text { mins after inhalation of } 400-800 \mu \mathrm{g} \text { salbutamol compared } \\
\text { to the mean AM PEF values in the preceding week, more than } 20 \% \text { variation between } \\
\text { AM and PM PEF on at least } 4 \text { consecutive days, } \mathrm{PC}_{20} \text { methacholine }<4 \mathrm{mg} / \mathrm{ml} \\
\text { Exclusion Criteria: not reported as such }\end{array}$} \\
\hline Interventions & \multicolumn{2}{|c|}{$\begin{array}{l}\text { 1. FP } 200+\text { SAL } 50 \mu \mathrm{g} \text { BD } \\
\text { 2. FP } 200 \mu \mathrm{g} \mathrm{BD} \\
\text { 3. FP } 500 \mu \mathrm{g} \text { BD (not used in this review) } \\
\text { Delivery was Discus device }\end{array}$} \\
\hline Outcomes & \multicolumn{2}{|c|}{$\begin{array}{l}\text { Primary end points were submucosal eosinophil and mast cell counts } \\
\text { No information in paper but zero SAEs reported on GSK website }\end{array}$} \\
\hline \multicolumn{3}{|l|}{ Notes } \\
\hline \multicolumn{3}{|l|}{ Risk of bias } \\
\hline Item & Authors' judgement & Description \\
\hline Adequate sequence generation? & Unclear & Not stated \\
\hline Allocation concealment? & Unclear & Not stated \\
\hline $\begin{array}{l}\text { Blinding? } \\
\text { All outcomes }\end{array}$ & Yes & Double blind \\
\hline
\end{tabular}


Wallin 2003 (Continued)

\begin{tabular}{l|l|l}
$\begin{array}{l}\text { Incomplete outcome data addressed? } \\
\text { All outcomes }\end{array}$ & Yes & $46 / 56(82 \%)$ completed the study \\
\hline Free of selective reporting? & Yes & SAE data on GSK website \\
\hline
\end{tabular}

\section{Characteristics of excluded studies [ordered by study ID]}

\begin{tabular}{|c|c|}
\hline Study & Reason for exclusion \\
\hline Adinoff 1998 & Not randomised to ICS \\
\hline Adolfsson 2005 & Dose response study \\
\hline Bateman 1998 & Device comparison \\
\hline Bateman 2006 & Higher dose ICS in control arm \\
\hline Baumgarten 2002 & 4 week study \\
\hline Bergmann 2004 & Higher dose ICS in control arm \\
\hline Bjermer 2000 & Salmeterol versus LRTA \\
\hline Bjermer 2003 & Salmeterol versus LRTA \\
\hline Bleecker 2006 & Salmeterol versus Salmeterol/Fluticasone \\
\hline Bleecker 2007 & Review \\
\hline Bleecker 2008 & Salmeterol versus LRTA \\
\hline Bracamonte 2005 & Device comparison \\
\hline Busse 2006 & Cross-over study \\
\hline Calhoun 2001 & Salmeterol versus LRTA \\
\hline Chapman 1999 & Device comparison \\
\hline Condemi 1999 & Higher dose ICS in control arm \\
\hline Cook 1998 & Higher dose ICS in control arm \\
\hline D’Urzo 2001 & 6 week duration \\
\hline
\end{tabular}


(Continued)

\begin{tabular}{|c|c|}
\hline Del 2001 & Salmeterol versus LRTA \\
\hline Deykin 2007 & Comparison between different combined inhalers \\
\hline Didier 1997 & No ICS control arm \\
\hline Dorinsky 2004 & Comparison between different combined inhalers \\
\hline Faurschou 1994 & 3 week cross-over study \\
\hline Fish 2001 & Salmeterol versus LRTA \\
\hline Fujimoto 2006 & Salmeterol versus tolobuterol \\
\hline GlaxoSmithKline 2004 & Higher dose ICS in control arm \\
\hline GlaxoSmithKline 2005 & Higher dose ICS in control arm \\
\hline GlaxoSmithKline 2005a & Salmeterol versus LRTA \\
\hline GlaxoSmithKline 2005c & Device comparison \\
\hline GlaxoSmithKline 2005d & Higher dose ICS in control arm \\
\hline GlaxoSmithKline 2005e & Cross-over study \\
\hline Greening 1994 & Higher dose ICS in control arm \\
\hline Grutters 1999 & 8 week duration \\
\hline House 2004 & 2 week duration \\
\hline Ilowite 2004 & Salmeterol versus LRTA \\
\hline Isabelle 2001 & Device comparison \\
\hline Jarjour 2006 & FPS compared to higher dose FP \\
\hline Johansson 2001 & Different ICS in control arm \\
\hline Juniper 2002 & Different ICS in control arm \\
\hline Kelsen 1999 & Higher dose ICS in control arm \\
\hline Koopmans 2005 & Single dose study \\
\hline Lazarus 2001 & Not randomised to ICS \\
\hline
\end{tabular}


(Continued)

\begin{tabular}{|c|c|}
\hline Lemanske 2001 & Not randomised to ICS \\
\hline Lotvall & Single dose study \\
\hline Lundback 2000 & Different ICS in control arm \\
\hline Martinat 2003 & Device comparison \\
\hline Morice 2006 & Comparison between two different combined inhalers \\
\hline Murray 1999 & Higher dose ICS in control arm \\
\hline Nan 2004 & Different ICS in control arm \\
\hline Nathan 2001 & Review of SAS30003 and SAS30004 \\
\hline Nelson 2000 & Salmeterol versus LRTA \\
\hline Nelson 2001 & Salmeterol versus LRTA \\
\hline O’Byrne 2005 & Different ICS in control arm \\
\hline O’Connor 2004 & Salmeterol versus LRTA \\
\hline Pauwels 1998 & Different ICS in control arm and salmeterol given in both groups \\
\hline Pearlman 1999 & 4 week study \\
\hline Peters 2007 & Higher dose ICS in control arm \\
\hline Ringdal 2003 & Salmeterol versus LRTA \\
\hline Rosenthal 1999 & No randomisation to ICS \\
\hline Russell 1995 & No randomisation to ICS \\
\hline SAM30002 & FPS compared to Budesonide at higher dose \\
\hline SAM30013 & FPS compared with higher dose fluticasone \\
\hline SAM 40116 & Patients with asthma and COPD compared to higher dose fluticasone \\
\hline SAS30015 & FPS compared to BDP \\
\hline Schermer 2007 & Higher dose ICS in control arm \\
\hline Schlosser 1998 & Device comparison \\
\hline
\end{tabular}


(Continued)

\begin{tabular}{ll}
\hline Scott 2005 & Device comparison \\
\hline SLGA5021 & FPS comparison with higher dose fluticasone \\
\hline Tonnel 2004 & Device comparison in acute asthma \\
\hline Van den 2000 & Device comparison \\
\hline Van Noord 1999 & Higher dose ICS in control arm \\
\hline Vermetten 1999 & Higher dose ICS in control arm \\
\hline Woolcock 1996 & Higher dose ICS in control arm \\
\hline You-Ning 2005 & Device comparison \\
\hline Zhong 2002 & Device comparison \\
\hline Zhong 2005 & Comparison to different ICS in control arm \\
\hline
\end{tabular}


DATA AND ANALYSES

Comparison 1. Regular Salmeterol in addition to regular inhaled corticosteroids

\begin{tabular}{lccll} 
Outcome or subgroup title & $\begin{array}{c}\text { No. of } \\
\text { studies }\end{array}$ & $\begin{array}{c}\text { No. of } \\
\text { participants }\end{array}$ & Statistical method & Effect size \\
\hline 1 All-cause mortality & 33 & 12046 & Peto Odds Ratio (Peto, Fixed, 95\% CI) & $1.05[0.32,3.47]$ \\
1.1 Adults and adolescents & 30 & 10873 & Peto Odds Ratio (Peto, Fixed, 95\% CI) & $1.05[0.32,3.47]$ \\
1.2 Children & 3 & 1173 & Peto Odds Ratio (Peto, Fixed, 95\% CI) & Not estimable \\
2 All-cause non-fatal SAE & 33 & 12046 & Peto Odds Ratio (Peto, Fixed, 95\% CI) & $1.16[0.90,1.50]$ \\
2.1 Adults & 30 & 10873 & Peto Odds Ratio (Peto, Fixed, 95\% CI) & $1.17[0.90,1.52]$ \\
2.2 Children & 3 & 1173 & Peto Odds Ratio (Peto, Fixed, 95\% CI) & $0.75[0.17,3.31]$ \\
3 All-cause SAE (fatal and & 33 & 12046 & Peto Odds Ratio (Peto, Fixed, 95\% CI) & $1.15[0.90,1.48]$ \\
non-fatal) & & & & \\
3.1 Adults & 30 & 10873 & Peto Odds Ratio (Peto, Fixed, 95\% CI) & $1.17[0.91,1.51]$ \\
3.2 Children & 3 & 1173 & Peto Odds Ratio (Peto, Fixed, 95\% CI) & $0.75[0.17,3.31]$ \\
4 Asthma-related SAE & 33 & 12046 & Peto Odds Ratio (Peto, Fixed, 95\% CI) & $0.91[0.50,1.64]$ \\
4.1 Adults & 30 & 10873 & Peto Odds Ratio (Peto, Fixed, 95\% CI) & $0.95[0.52,1.73]$ \\
4.2 Children & 3 & 1173 & Peto Odds Ratio (Peto, Fixed, 95\% CI) & $0.14[0.00,6.82]$ \\
\hline
\end{tabular}


Analysis I.I. Comparison I Regular Salmeterol in addition to regular inhaled corticosteroids, Outcome I All-cause mortality.

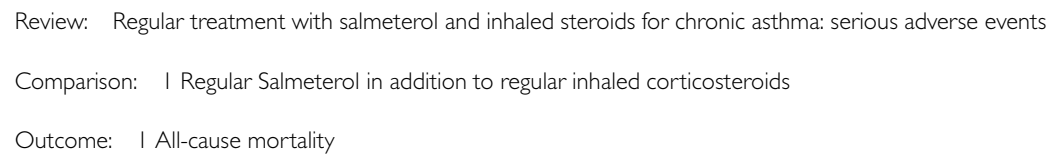

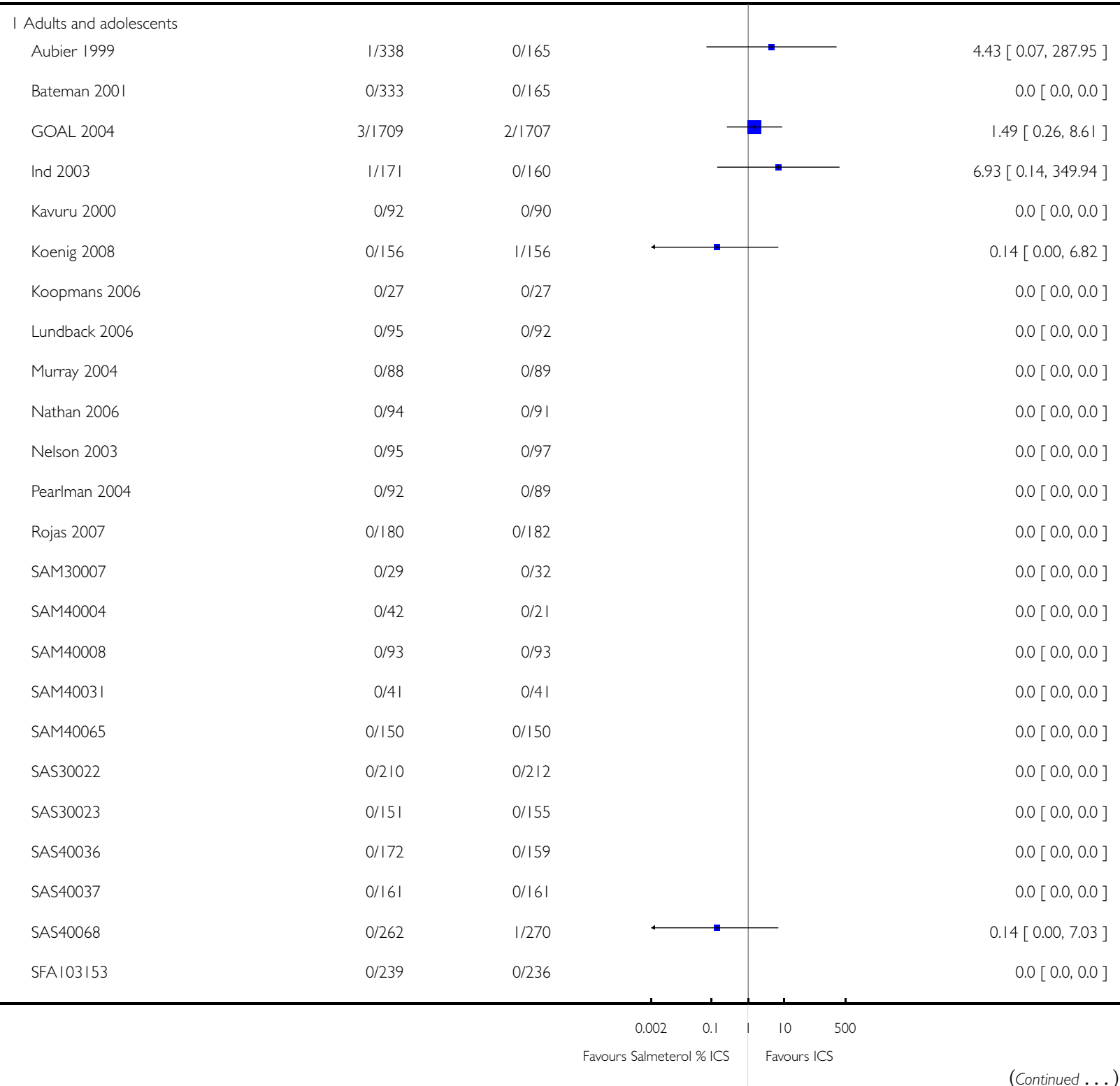




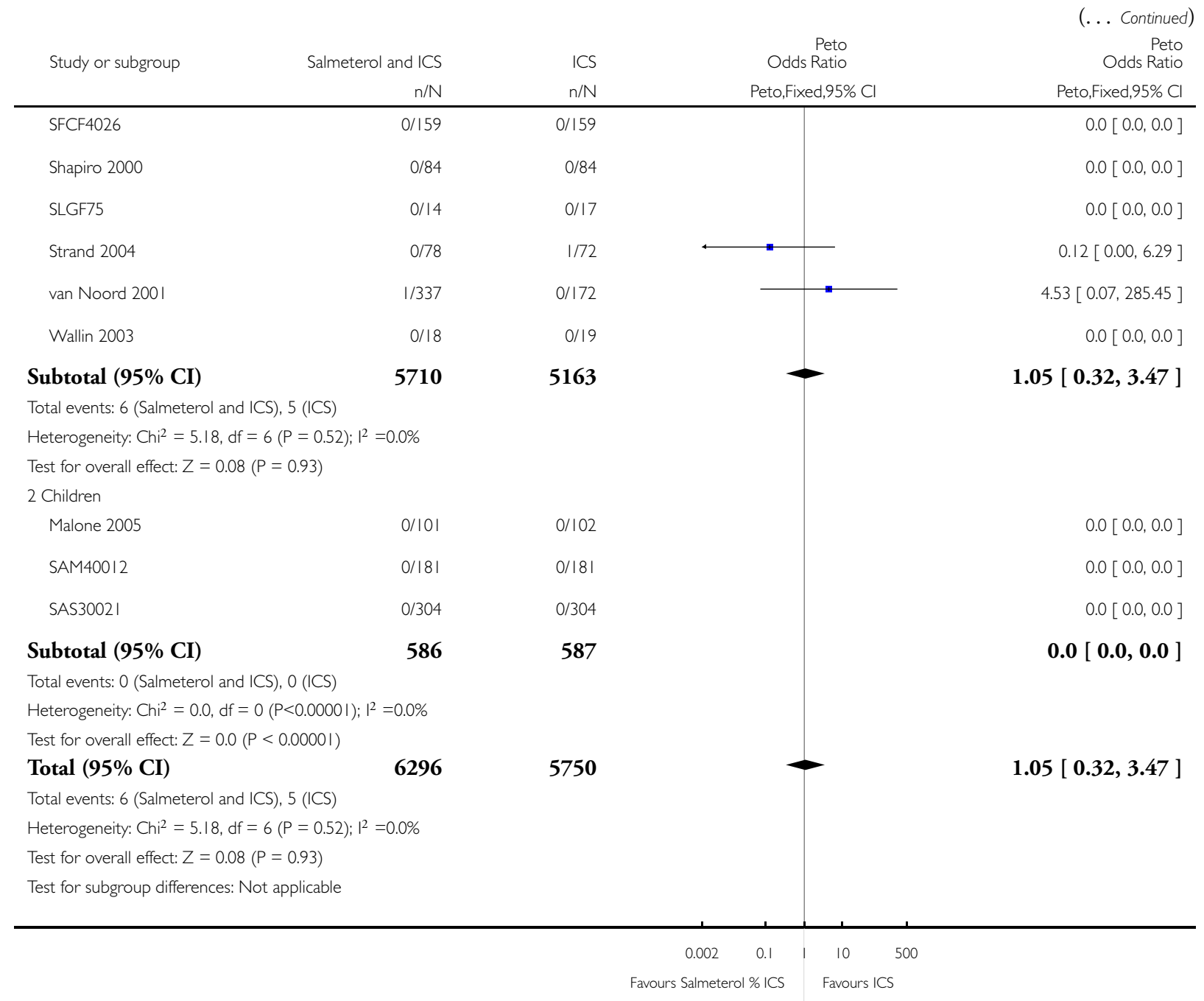


Analysis I.2. Comparison I Regular Salmeterol in addition to regular inhaled corticosteroids, Outcome 2 All-cause non-fatal SAE.

Review: Regular treatment with salmeterol and inhaled steroids for chronic asthma: serious adverse events

Comparison: I Regular Salmeterol in addition to regular inhaled corticosteroids

Outcome: 2 All-cause non-fatal SAE

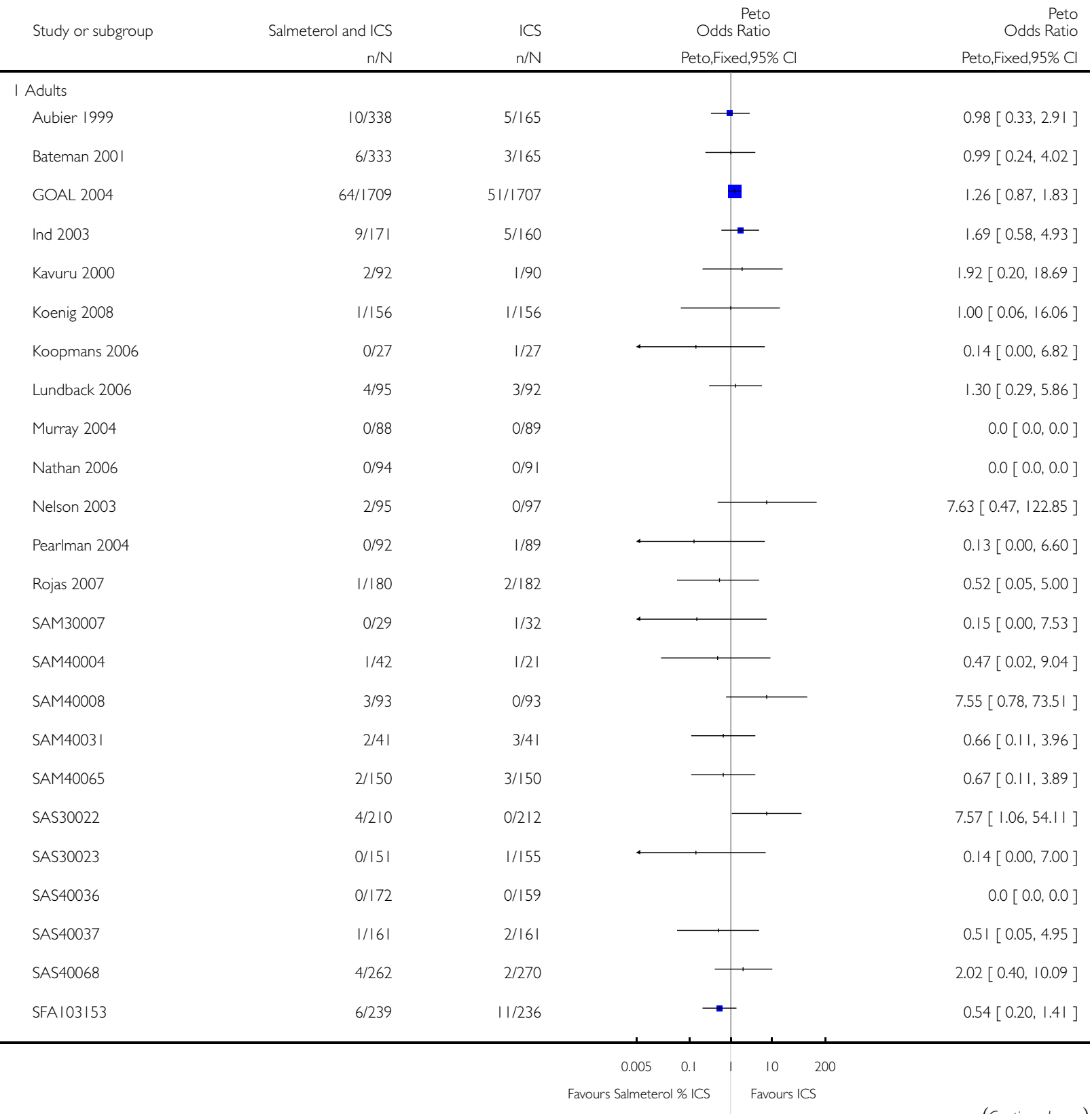

(Continued ...) 


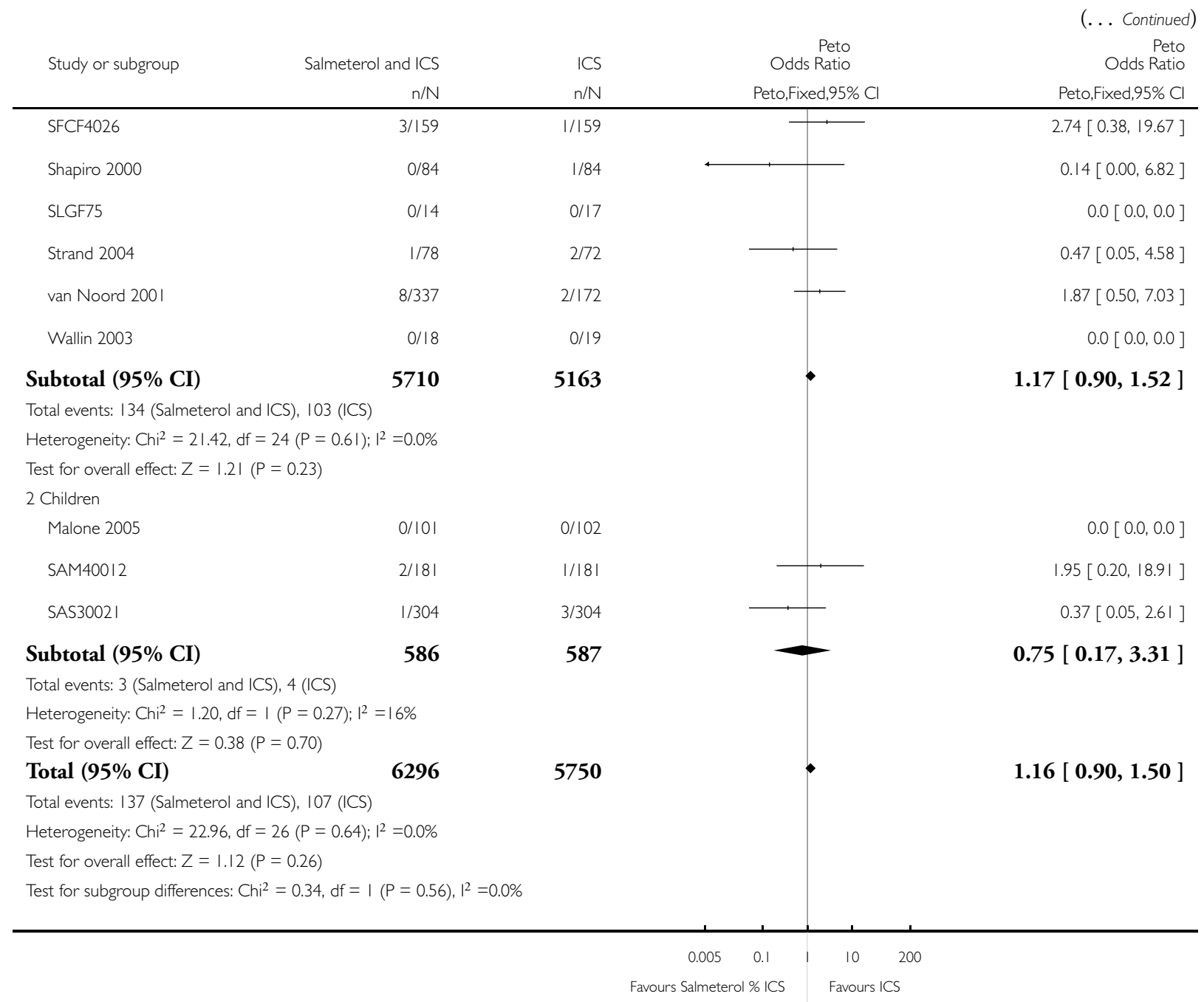


Analysis I.3. Comparison I Regular Salmeterol in addition to regular inhaled corticosteroids, Outcome 3 All-cause SAE (fatal and non-fatal).

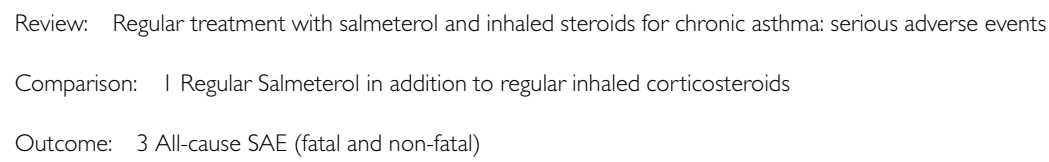

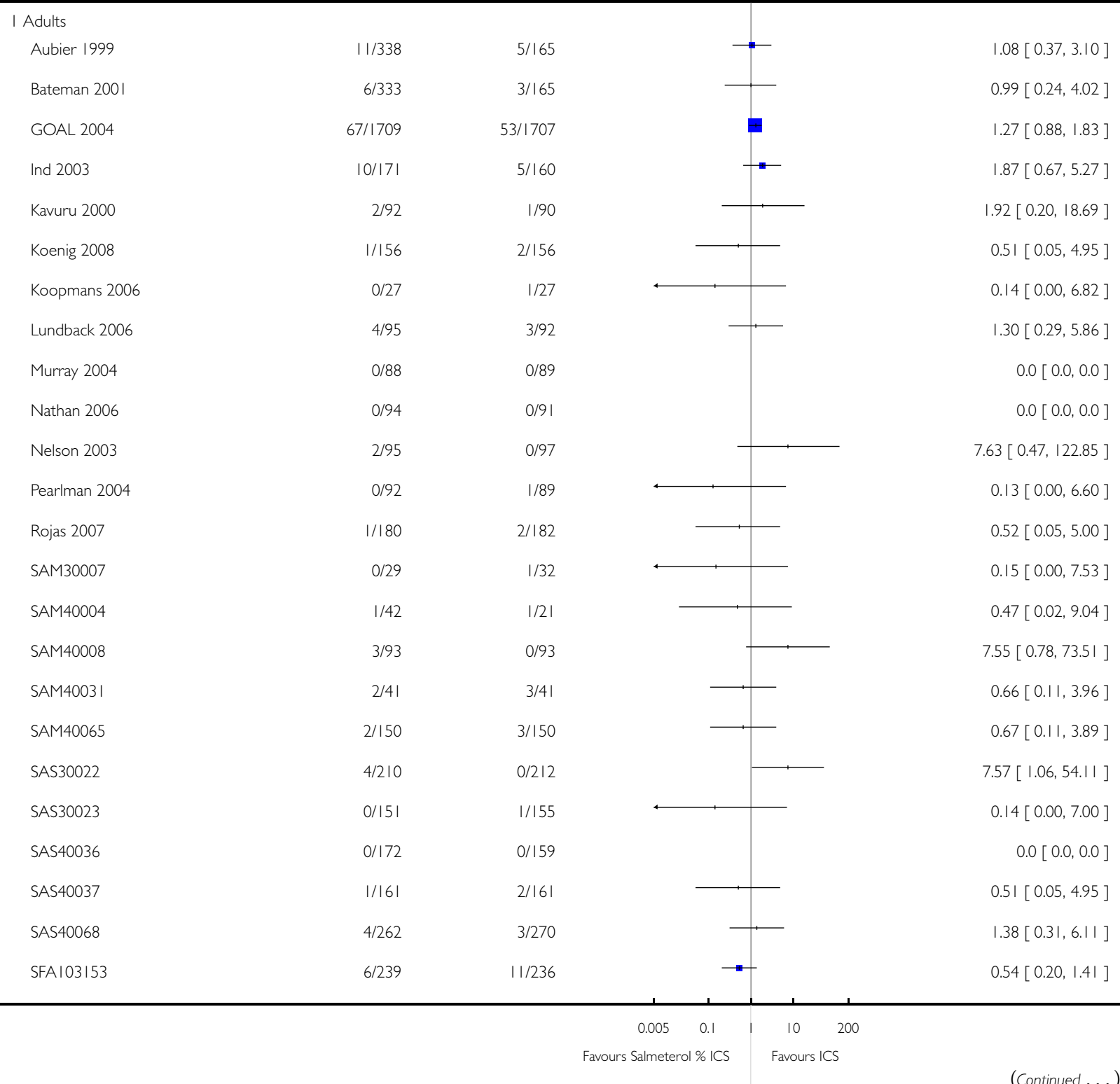




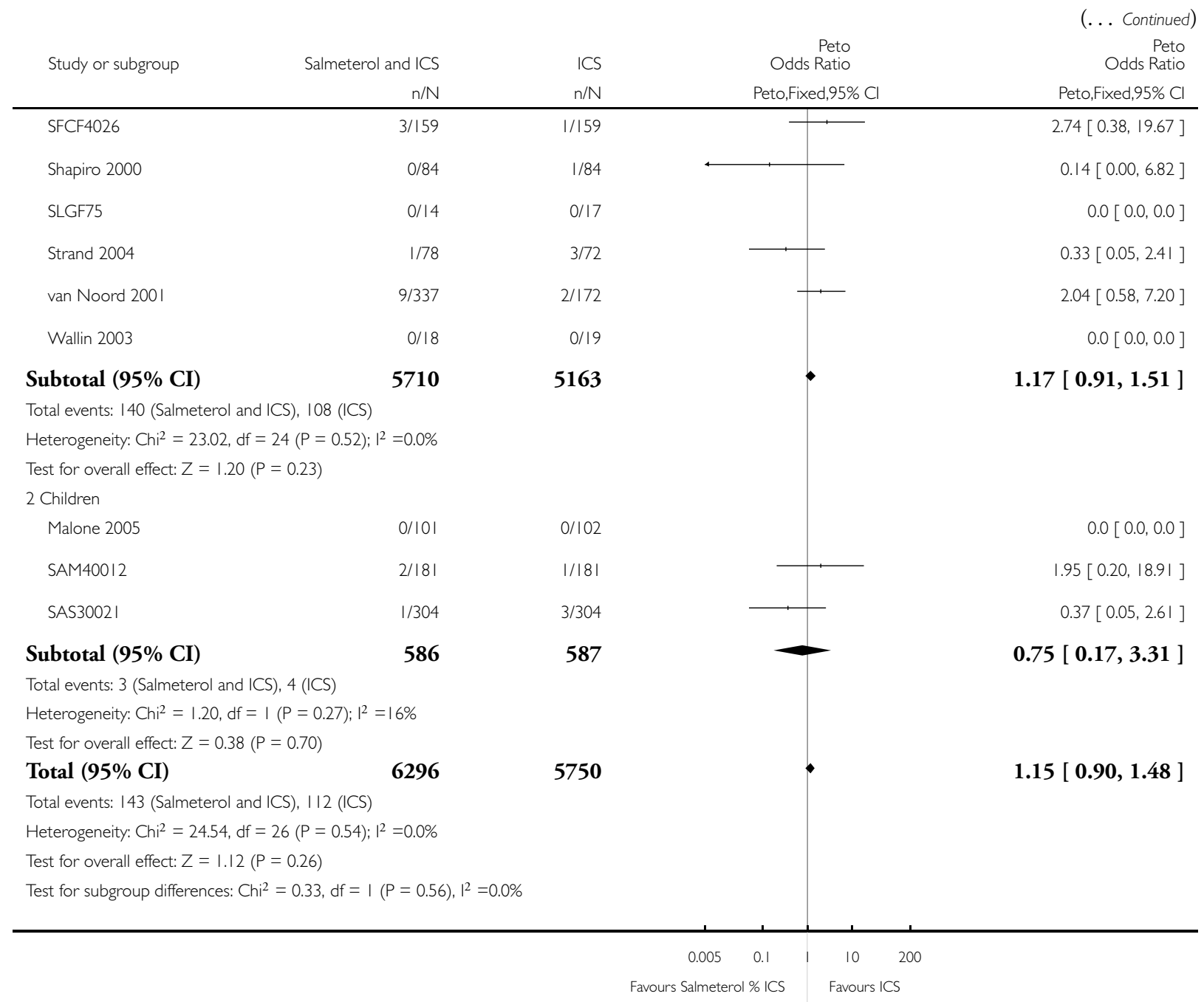


Analysis I.4. Comparison I Regular Salmeterol in addition to regular inhaled corticosteroids, Outcome 4 Asthma-related SAE.

Review: Regular treatment with salmeterol and inhaled steroids for chronic asthma: serious adverse events

Comparison: I Regular Salmeterol in addition to regular inhaled corticosteroids

Outcome: 4 Asthma-related SAE

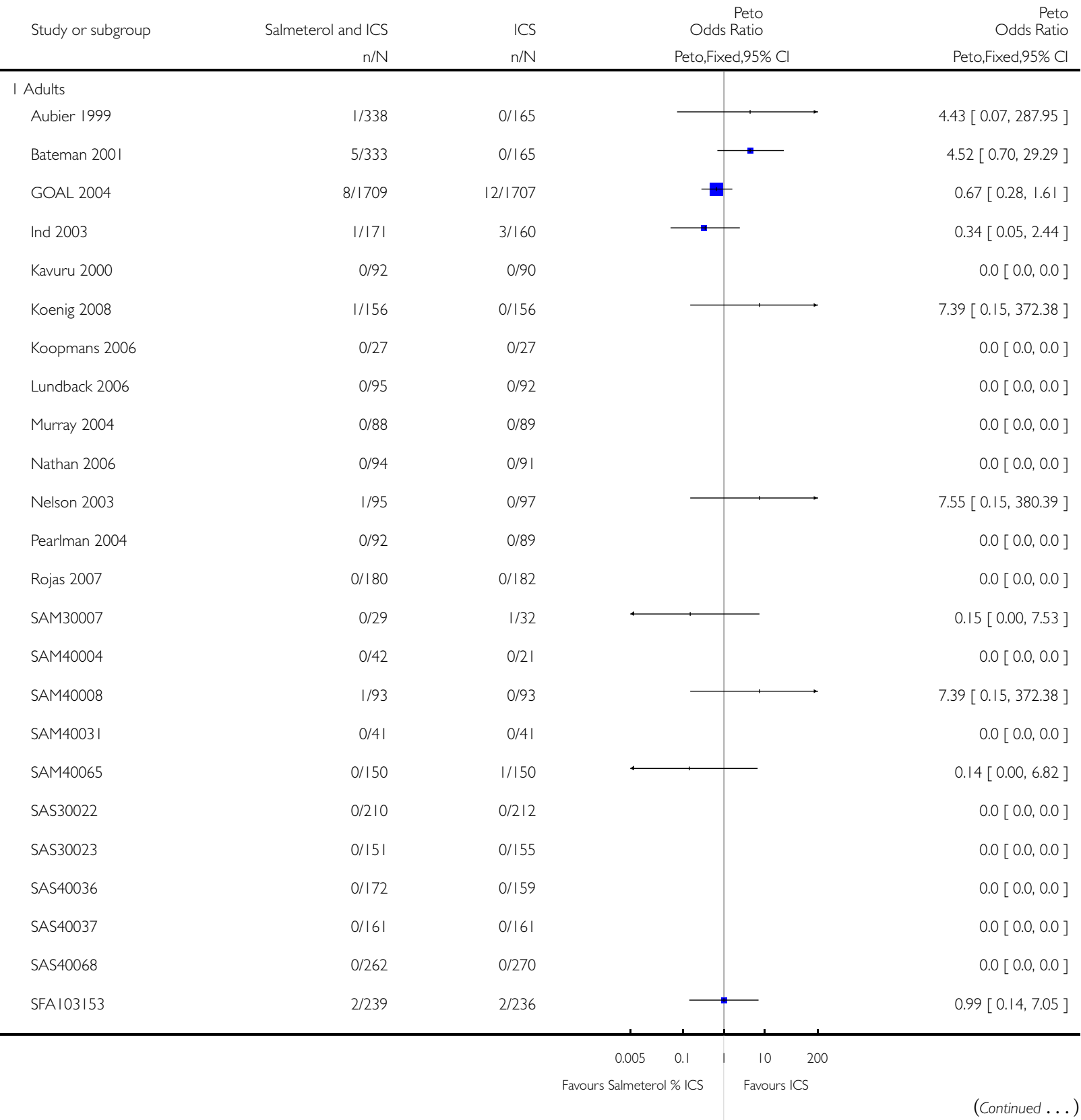




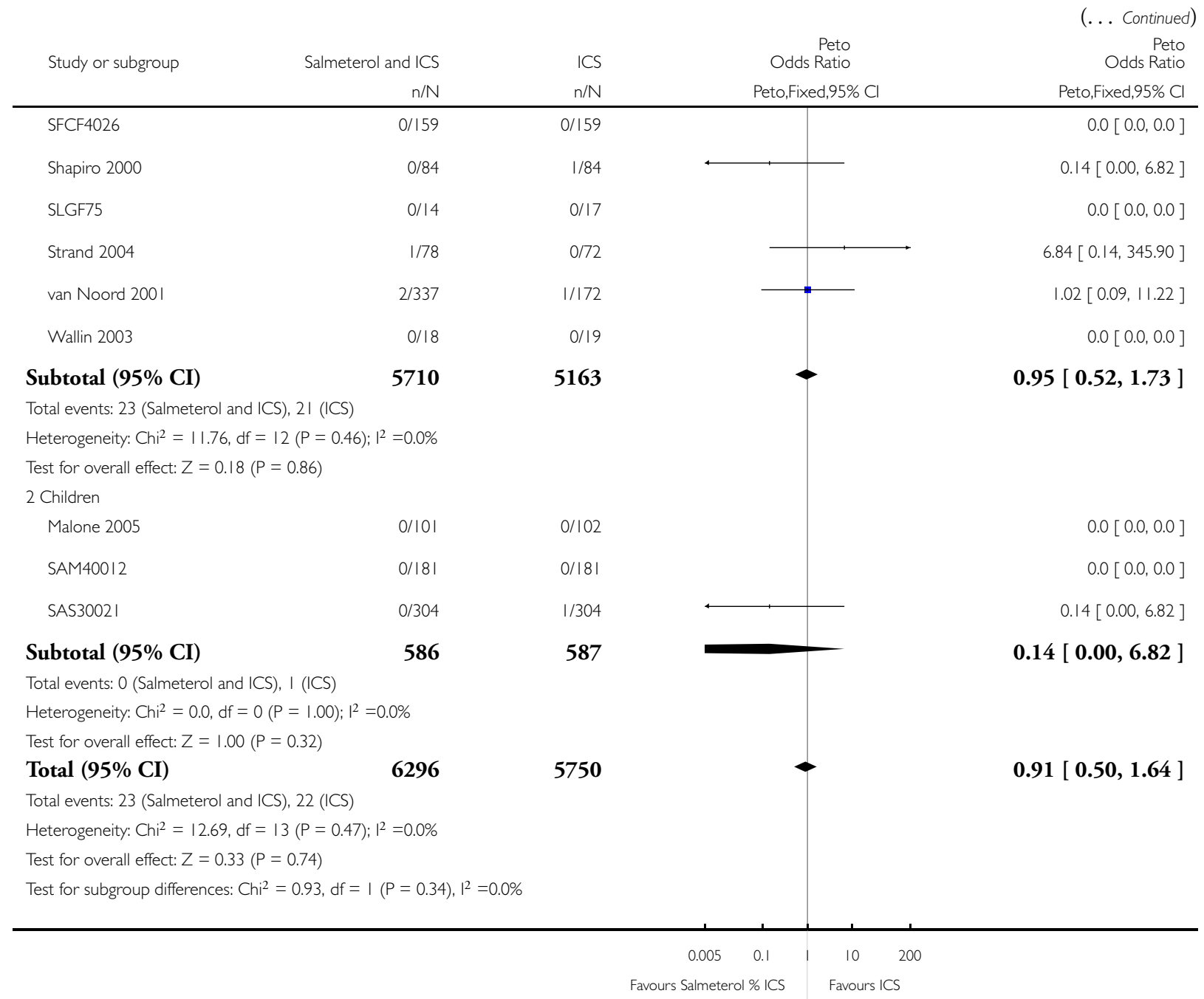

ADDITIONAL TABLES

Table 1. Dose of Salmeterol and Fluticasone

\begin{tabular}{|c|c|c|c|c|c|}
\hline Study ID & $\begin{array}{l}\text { Age of Participants } \\
\text { (Years) }\end{array}$ & $\begin{array}{l}\text { Daily dose of Fluti- } \\
\text { casone (mcg) }\end{array}$ & $\begin{array}{l}\text { Daily dose of Sal- } \\
\text { meterol (mcg) }\end{array}$ & Combined Inhaler & Separate Inhalers \\
\hline Aubier 1999 & $12+$ & 1000 & 100 & $\sqrt{ }$ & $\sqrt{ }$ \\
\hline Bateman 2001 & $12+$ & 200 & 100 & $\sqrt{ }$ & \\
\hline GOAL 2004 & $12+$ & $200 / 500 / 1000$ & 100 & $\sqrt{ }$ & \\
\hline
\end{tabular}


Table 1. Dose of Salmeterol and Fluticasone (Continued)

\begin{tabular}{|c|c|c|c|c|c|}
\hline Ind 2003 & $16+$ & 500 & 100 & & $\sqrt{ }$ \\
\hline Kavuru 2000 & $12+$ & 200 & 100 & $\sqrt{ }$ & \\
\hline Koenig 2008 & $12+$ & $200 / 500 / 1000$ & 100 & $\sqrt{ }$ & \\
\hline Koopmans 2006 & $18+$ & 500 & 100 & $\sqrt{ }$ & \\
\hline Lundback 2006 & $18+$ & 500 & 100 & $\sqrt{ }$ & \\
\hline Malone 2005 & 4 to 11 & 200 & 100 & $\sqrt{ }$ & \\
\hline Murray 2004 & $12+$ & 200 & 100 & $\sqrt{ }$ & \\
\hline Nathan 2006 & $12+$ & 220 & 100 & $\sqrt{ }$ & \\
\hline Nelson 2003 & $12+$ & 200 & 100 & $\sqrt{ }$ & \\
\hline Pearlman 2004 & $12+$ & 200 & 100 & $\sqrt{ }$ & \\
\hline Rojas 2007 & $12+$ & 500 & 100 & $\sqrt{ }$ & \\
\hline SAM30007 & $18+$ & $200 / 500 / 1000$ & 100 & $\sqrt{ }$ & \\
\hline SAM40004 & $18+$ & 200 & 100 & $\sqrt{ }$ & \\
\hline SAM 40008 & $18+$ & 1000 & 100 & $\sqrt{ }$ & \\
\hline SAM40012 & 4 to 11 & 200 & 100 & $\sqrt{ }$ & \\
\hline SAM40031 & $18+$ & $200 / 500 / 1000$ & 100 & $\sqrt{ }$ & \\
\hline SAM40065 & $12+$ & $200 / 500 / 1000$ & 100 & $\sqrt{ }$ & \\
\hline SAS30021 & 4 to 11 & 100 & 50 & $\sqrt{ }$ & \\
\hline SAS30022 & $12+$ & 500 & 50 & $\sqrt{ }$ & \\
\hline SAS30023 & $12+$ & 100 & 50 & $\sqrt{ }$ & \\
\hline SAS40036 & $15+$ & 200 & 100 & $\sqrt{ }$ & \\
\hline SAS40037 & $15+$ & 200 & 100 & $\sqrt{ }$ & \\
\hline SAS40068 & $12+$ & 200 & 100 & $\sqrt{ }$ & \\
\hline SFA103153 & $12+$ & 200 & 100 & $\sqrt{ }$ & \\
\hline
\end{tabular}


Table 1. Dose of Salmeterol and Fluticasone (Continued)

\begin{tabular}{l|llll}
\hline SFCF4026 & $18+$ & 500 & 100 & $\sqrt{ }$ \\
\hline Shapiro 2000 & $12+$ & 500 & 100 & $\sqrt{ }$ \\
\hline SLGF75 & $16+$ & 200 & 100 & $\sqrt{ }$ \\
\hline Strand 2004 & $18+$ & 200 & 100 & $\sqrt{ }$ \\
\hline van Noord 2001 & $12+$ & 1000 & 100 & $\sqrt{ }$ \\
\hline Wallin 2003 & $12+$ & 400 & 100 & \\
\hline
\end{tabular}

\section{AP PENDICES}

\section{Appendix I. Pharmacology of beta begonists $_{2}$}

-agonists are thought to cause bronchodilation primarily through binding beta 2 -adrenoceptors on airways smooth muscle (ASM), with subsequent activation of both membrane-bound potassium channels and a signalling cascade involving enzyme activation and changes in intracellular calcium levels following a rise in cyclic adenosine monophosphate (cAMP) (Barnes 1993). However, beta 2 adrenoceptors are also expressed on a wide range of cell types where beta 2 -agonists may have a clinically significant effect including airway epithelium (Morrison 1993), mast cells, post capillary venules, sensory and cholinergic nerves and dendritic cells (Anderson

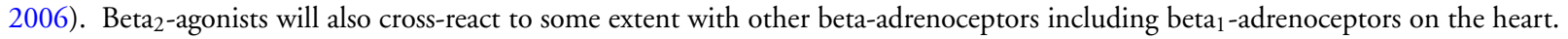
The in vivo effect of any beta 2 -agonist will depend on a number of factors relating to both the drug and the patient. The degree to which a drug binds to one receptor over another is known as selectivity, which can be defined as absolute binding ratios to different receptors in vitro, whilst functional selectivity is measured from downstream effects of drugs in different tissue types in vitro or in vivo. All of the beta2-agonists described thus far are more beta 2 selective than their predecessor isoprenaline in vitro. However, because attempts to differentiate selectivity between the newer agents are confounded by so many factors, it is difficult to draw conclusions about in vitro selectivity studies and probably best to concentrate on specific adverse side-effects in human subjects at doses which cause the same degree of bronchodilatation. The potency of a drug refers to the concentration that achieves half the maximal receptor activation of which that drug is capable but it is not very important clinically as for each drug, manufacturers will alter the dose to try to achieve a therapeutic ratio of desired to undesired effects. In contrast efficacy refers to the ability of a drug to activate its receptor independent of drug concentration. Drugs that fully activate a receptor are known as full agonists and those that partially activate a receptor are known as partial agonists. Efficacy also is very much dependent on the system in which it is being tested and is affected by factors including the number of receptors available and the presence of other agonists and antagonists. Thus whilst salmeterol acts as a partial agonist in vitro it causes a similar degree of bronchodilation to the strong agonist formoterol in stable asthmatic patients (vanNoord 1996), presumably because there are an abundance of well-coupled beta 2 -adrenoceptors available with few downstream antagonising signals. In contrast, with repetitive dosing formoterol is significantly better than salmeterol at preventing methacholineinduced bronchoconstriction (Palmqvist 1999). These differences have led to attempts to define the "intrinsic efficacy" of a drug independent of tissue conditions (Hanania 2002), as shown in Table 1. The clinical significance of intrinsic efficacy remains unclear. 


\section{Appendix 2. Possible mechanisms of increased asthma mortality with beta-agonists}

\section{Direct toxicity}

This hypothesis states that direct adverse effects of beta 2 -agonists are responsible for an associated increase in mortality and most research in the area has concentrated on effects detrimental to the heart. Whilst it is often assumed that cardiac side-effects of beta 2 -agonists

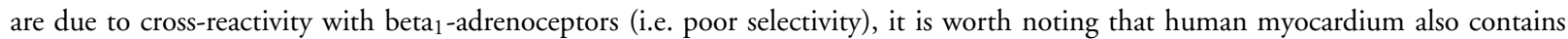
an abundance of beta 2 -adrenoceptors capable of triggering positive chronotropic and inotropic responses (Lipworth 1992). Indeed, there is good evidence that cardiovascular side-effects of isoprenaline (Arnold 1985) and other beta 2 -agonists including salbutamol (Hall 1989) are mediated predominantly via cardiac beta 2 -adrenoceptors thus making the concept of in vitro selectivity less relevant. Generalised beta2-adrenoceptor activation can also cause hypokalaemia (Brown 1983) and it has been proposed that, through these and other actions beta 2 -agonists may predispose to life-threatening dysrhythmias or cause other adverse cardiac effects.

During the 1960s epidemic most deaths occurred in patients with severe asthma and it was originally assumed that asthma and its sequelae, including hypoxia, were the primary cause of death. However, mucus plugging and hypoxia does not preclude a cardiac event as the final cause of death, and one might expect those with severe asthma to take more doses of a prescribed inhaler. As noted by Speizer and Doll most deaths in the 1960s were in the 10-19 age group and "at these ages children have begun to act independently and may be particularly prone to misuse a self-administered form of treatment" (Speizer 1968). If toxicity were related to increasing doses of beta $_{2}$-agonists one might expect most deaths to occur in hospital where high doses are typically used and this was not the case. One possible explanation for this anomaly was provided by animal experiments in which large doses of isoprenaline caused little ill effect in anaesthetised dogs with normal arterial oxygenation whereas much smaller doses caused fatal cardiac depression and asystole (although no obvious dysrhythmia) when hypoxic (Collins 1969; McDevitt 1974). It has been hypothesised therefore that such events would be less likely in hospital where supplemental oxygen is routinely given. The clinical relevance of these studies remains unclear although there is some evidence of a synergistic effect between hypoxia and salbutamol use in asthmatic patients in reducing total peripheral vascular resistance (Burggraaf 2001) - another beta 2 mediated effect which could be detrimental to the heart during an acute asthma attack through a reduction in diastolic blood pressure. Other potential mechanisms of isoprenaline toxicity include a potential increase in mucous plugging and worsening of ventilation perfusion mismatch despite bronchodilation (Pearce 1990).

Further concerns about a possible toxic effect of beta 2 -agonists were raised during the New Zealand epidemic in the 1970s. In 1981 Wilson et al who first reported the epidemic reviewed 22 fatal cases of asthma and noted "In 16 patients death was seen to be sudden and unexpected. Although all were experiencing respiratory distress, most were not cyanosed and the precipitate nature of their death suggested a cardiac event, such as an arrest, inappropriate to the severity of their respiratory problem" (Wilson 1981). In humans, fenoterol causes significantly greater chronotropic, inotropic and electrocardiographic side-effects than salbutamol in asthmatic patients (Wong 1990). Interestingly, across the same parameters fenoterol also causes more side-effects than isoprenaline (Burgess 1991).

In patients with mild asthma and without a bronchoconstrictor challenge, salmeterol and salbutamol cause a similar degree of near maximal bronchodilation at low doses (Bennett 1994). However, whilst as a one off dose salbutamol is typically used at 2-4 times the concentration of salmeterol, the dose equivalences for salmeterol versus salbutamol in increasing heart rate and decreasing potassium concentration and diastolic blood pressure were 17.7, 7.8 and 7.6 respectively (i.e. salmeterol had a greater effect across all parameters). Given the lower intrinsic efficacy of salmeterol (Table 2), these results highlight the importance of in vivo factors; one possible explanation for the difference is the increased lipophilicity of salmeterol compared to salbutamol contributing to higher systemic absorption (Bennett 1994).

When comparing increasing actuations of standard doses of formoterol and salmeterol inhalers in stable asthmatic patients, relatively similar cardiovascular effects are seen at lower doses (Guhan 2000). However, at the highest doses (above those recommended by the manufacturers) there were trends towards an increase in systolic blood pressure with formoterol; in comparison there was a trend towards a decrease in diastolic blood pressure and an increase in QTc interval with salmeterol although no statistical analysis of the difference was performed. In contrast in asthmatic patients with methacholine-induced bronchoconstriction there was no significant difference between salmeterol and formoterol in causing increased heart rate and QTc interval although formoterol caused significantly greater bronchodilation and hypokalaemia (Palmqvist 1999). Whilst there is good evidence of cardiovascular and metabolic side-effects with increasing doses of beta 2 -agonists, it is a little difficult to envisage serious adverse effects of this nature when using LABAs at manufacturer-recommended preventative doses. However, it is possible that some patients choose to use repeated doses of LABAs during exacerbations.

Regular treatment with salmeterol and inhaled steroids for chronic asthma: serious adverse events (Review) 


\section{Tolerance}

In this setting, the term tolerance refers to an impaired response to beta 2 -agonists in patients who have been using regular beta 2 agonist treatment previously (Haney 2006). Tolerance is likely to result from a combination of reduced receptor numbers secondary to receptor internalisation and reduced production and also uncoupling of receptors to downstream signalling pathways following repeated activation (Barnes 1995). This phenomenon is likely to explain the beneficial reduction in systemic side effects seen with regular use of beta 2 -agonists including salbutamol after 1-2 weeks (Lipworth 1989). However, the same effect on beta 2 -adrenoceptors in the lung might be expected to produce a diminished response to the bronchodilating activity of beta 2 -agonists following regular use. In patients with stable asthma, whilst there is some evidence of tolerance to both salbutamol (Nelson 1977) and terbutaline (Weber 1982) other studies have been less conclusive (Harvey 1982; Lipworth 1989). However, evidence of tolerance to short and long-acting beta2agonists in both protecting against and reducing bronchoconstriction is much stronger in the setting of an acute bronchoconstrictor challenge with chemical, allergen and 'natural' stimuli ( Haney 2006; Lipworth 1997).

Studies comparing salmeterol and formoterol have shown that both cause tolerance compared to placebo but there was no significant difference between the drugs (van der Woude 2001). There also appears to be little difference in the tolerance induced by regular formoterol and regular salbutamol treatment (Hancox 1999; Jones 2001). To the authors' knowledge no studies have looked specifically at the degree of tolerance caused by isoprenaline and fenoterol in the setting of acute bronchoconstriction. Tolerance to bronchodilation has been shown to clearly occur with addition of inhaled corticosteroids to salmeterol and formoterol (Lee 2003) and terbutaline (Yates 1996). There is conflicting evidence as to whether high dose steroids can reverse tolerance in the acute setting (Lipworth 2000; Jones 2001).

At first glance the toxicity and tolerance hypotheses might appear incompatible as systemic and cardiovascular tolerance ought to protect against toxicity in the acute setting and there is good evidence that such tolerance occurs in stable asthmatic patients (Lipworth 1989). However, whilst this study showed that changes in heart rate and potassium levels were blunted by previous beta 2 -agonist use, they were not abolished; furthermore, at the doses studied these side-effects appear to follow an exponential pattern (Lipworth 1989). In contrast, in the presence of bronchoconstrictor stimuli the bronchodilator response to beta 2 -agonists follows a flatter curve (Wong 1990; Hancox 1999) and as previously discussed this curve is shifted downwards by previous beta 2 -agonist exposure (Hancox 1999). Thus, it is theoretically possible that in the setting of an acute asthmatic attack and strong bronchoconstricting stimuli, bronchodilator tolerance could lead to repetitive beta2-agonist use and ultimately more systemic side-effects than would otherwise have occurred. Of course, other sequelae of inadequate bronchodilation including airway obstruction will be detrimental in this setting.

Whilst the tolerance hypothesis is often cited as contributing towards the asthma mortality epidemics it is difficult to argue that reduced efficacy of a drug can cause increased mortality relative to a time when that drug was not used at all. However, tolerance to the bronchodilating effect of endogenous circulating adrenaline is theoretically possible and there is also evidence of rebound bronchoconstriction when stopping fenoterol (Sears 1990), which may be detrimental. Furthermore, it appears that regular salbutamol treatment can actually increase airway responsiveness to allergen (Cockcroft 1993) a potentially important effect that could form a variant of the toxicity hypothesis. Differences between beta 2 -agonists in this regard are unclear, but the combination of rebound hyperresponsiveness and tolerance of the bronchodilator effect with regular beta2-agonist exposure has been recently advocated as a possible mechanism to explain the association between beta2-agonists and asthma mortality (Hancox 2006).

\section{Other explanations}

\section{Confounding by severity}

Historically, this hypothesis has been used extensively to try to explain the association between mortality and the use of fenoterol during the 1970s New Zealand epidemic (see Pearce 2007) and is still quoted today. The hypothesis essentially relies on the supposition that patients with more severe asthma are more likely to take either higher doses of beta 2 -agonists or a particular beta 2 -agonist (such as fenoterol) thereby explaining the association. This hypothesis was carefully ruled out in the three case-control studies by comparing the association between fenoterol and mortality in patients with varying severity of disease (Crane 1989; Pearce 1990; Grainger 1991). Furthermore, the hypothesis cannot explain the overall increase in mortality in the 1960s and 1970s nor can it explain any significant increase in mortality (whether taking inhaled steroids or not) from randomised controlled trial data.

\section{The delay hypothesis}

This hypothesis accepts that beta 2 -agonists or a particular beta 2 -agonist cause an increased risk of mortality but indirectly by causing patients to delay before getting medical help and further treatments including high dose steroids and oxygen. There is evidence that 
both salmeterol and formoterol can reduce awareness of worsening underlying inflammation (Bijl-Hofland 2001; McIvor 1998). It is difficult to rule out the delay hypothesis in either explaining or contributing towards both the asthma mortality epidemics and an association with regular use of LABAs. There is evidence that beta 2 -agonists with higher intrinsic efficacy are more effective at relieving bronchoconstriction in the acute setting (Hanania 2007) and could paradoxically cause patients to delay seeking medical help for longer. For the delay hypothesis to explain the increase in mortality during the 1960s and 1970s one has to imply that hospital treatment of asthma when mortality rates were low during the earlier years of the $20^{\text {th }}$ century was effective. It is difficult to say exactly how effective such treatment is likely to have been.

\section{Reduced corticosteroid treatment}

A slight but significant variation of the delay hypothesis suggests that patients who have separate beta2-agonists and corticosteroid inhalers may choose to take less corticosteroid because of better symptom control from the inhaled beta 2 -agonists and it is reduced corticosteroid treatment that contributes to a rise in mortality. It is rather difficult to see how this hypothesis explains the epidemics of asthma deaths in the 1960s and 1970s relative to the 1920s and 30s, given that corticosteroids were not used for the treatment of asthma in the earlier decades. If this hypothesis were to explain increased mortality from more recent randomised controlled trial data one would not expect to see an increase in mortality in those taking LABAs alone.

\section{H I S T O R Y}

Protocol first published: Issue 1, 2008

Review first published: Issue 3, 2009

\section{CONTRIBUTIONS OFAUTHORS}

CJC: Conception of the idea and co-writing of protocol with MJC.

TL: Co-writing of the protocol, trial selection, data extraction and co-writing the review.

RJ: Trial selection, data extraction and co-writing the review.

\section{DECLARATIONS OF INTEREST}

In the past three years, Dr Jaeschke received honoraria for lectures from Boehringer Ingelheim (2006; 4000 US \$) and GlaxoSmithKline (2007; 2000 Euros) and travel support from Boehringer Ingelheim and GlaxoSmithKline (2006 and 2007; up to 1000 US \$).

\section{SOURCES OF SUPPORT}

\section{Internal sources}

- NHS R\&D, UK. 


\section{External sources}

- No sources of support supplied

\section{DIFFERENCES BETWEEN PROTOCOLANDREVIEW}

Although the protocol originally included studies comparing salmeterol and ICS with higher doses of ICS, we restricted this review to studies randomising patients to the same dose of ICS with and without salmeterol. Due to problems with fixed continuity corrections for zero cells we have used the Peto OR as the primary metric for analysis of relative measures, and the risk difference for absolute measures. Subgroup analysis was not attempted on the basis of asthma severity or dose of ICS.

\section{N D X T E R M}

\section{Medical Subject Headings (MeSH)}

Adolescent; Adrenal Cortex Hormones [administration \& dosage; * adverse effects]; Adrenergic beta-Agonists [administration $\&$ dosage; *adverse effects]; Albuterol [administration \& dosage; adverse effects; *analogs \& derivatives]; Anti-Asthmatic Agents [administration $\&$ dosage; *adverse effects]; Asthma [drug therapy; * mortality]

\section{MeSH check words}

Adult; Child; Humans; Young Adult 